Portland State University

PDXScholar

1985

\title{
Geology and geochemistry of hydrothermal alteration, eastern portion of the North Santiam mining area
}

J. Michael Pollock

Portland State University

Follow this and additional works at: https://pdxscholar.library.pdx.edu/open_access_etds

Part of the Geochemistry Commons, and the Geology Commons Let us know how access to this document benefits you.

\section{Recommended Citation}

Pollock, J. Michael, "Geology and geochemistry of hydrothermal alteration, eastern portion of the North Santiam mining area" (1985). Dissertations and Theses. Paper 3582.

https://doi.org/10.15760/etd.5466

This Thesis is brought to you for free and open access. It has been accepted for inclusion in Dissertations and Theses by an authorized administrator of PDXScholar. Please contact us if we can make this document more accessible: pdxscholar@pdx.edu. 
AN ABSTRACT OF THE THESIS OF J. Michael Pollock for the Master of Science in Geology presented June 12, 1985.

Title: Geology and geochemistry of hydrothermal alteration, eastern portion of the North Santiam mining area.

APPROVED BY MEMBERS OF THE THESIS COMMITTEE:

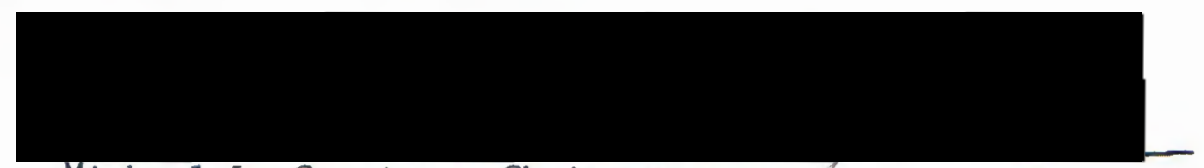

Michael L. Cummings, Chairman

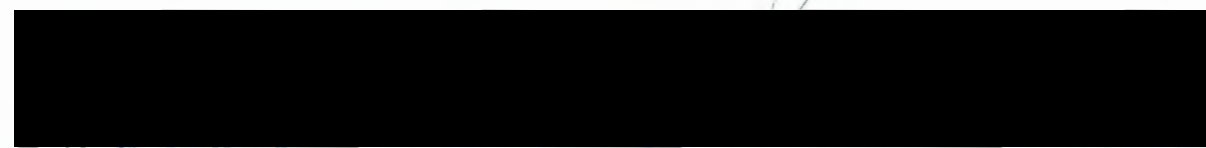

Marvin H. Beeson

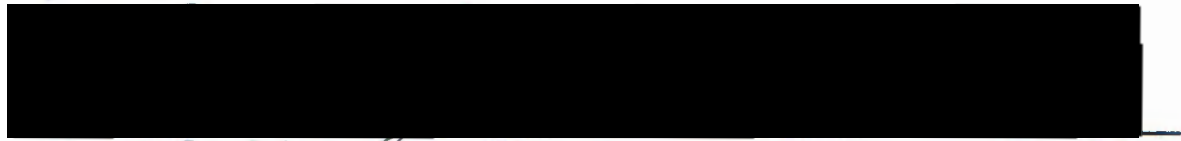

Ansel G. Johnsger

The Ruth Mine is a base-metal vein deposit near the eastern margin of a reported porphyry copper deposit in the Western Cascade Range in Oregon. Uplift of the Western Cascade Range has resulted in a deeply dissected terrain in which more than a kilometer of the stratigraphy overlying the porphyry-style mineralization is preserved and exposed. The stratigraphic units, which are middle Tertiary in age, have been given arbitrary letter designations beginning with the lowest unit (Unit A) through the uppermost unit (Unit D).

Unit A is composed of fragmental rocks of andesitic composition. Overlying and interlayered with Unit A are a sequence of light gray 
porphyritic andesite flows designated as Unit $B$. Unit $C$ is a sequence composed primarily of tuffs with compositions ranging from hornblende andesites to dacites and includes a finely laminated volcaniclastic sediment. Unit $\mathrm{D}$ is composed of dark brown to black porphyitic andesite flows deposited locally in an intracanyon relationship to the tuffs of Unit C. Base-metal veins in the area are hosted in the tuffs of Unit $A$ and the flows of Unit $B$.

Equigranular and porphyritic diorite intrusions crop out as northwest-trending dikes which were emplaced along faults with a N. 30$40^{\circ} \mathrm{W}$. trend. The last intrusions emplaced were a set of leucocratic quartz-feldspar porphyry dikes and sills. These latter intrusions were not controlled strongly by structure and, although they have not been dated, may have been emplaced as part of $11.8-11.0 \mathrm{~m} . \mathrm{y}$. B.P. volcanic activity previously reported on French Creek Ridge to the south. Units $C$ and $D$ include deposits from this volcanic center and cap the stratigraphic sequence in the mining area.

Folds with a $\mathrm{N} .70-80^{\circ}$ E. trending axis result in southeast dips on units in the area. These folds appear to have been developing throughout the deposition of Units A through D.

Propylitic alteration is widespread and is of two types. 1) Pervasive replacement of groundmass and phenocryst phases by chlorite, epidote, calcite, and albite is intense low in the section and decreases with increasing stratigraphic position. This alteration reflects isochemical recrystallization resulting from burial and elevated geothermal gradients; 2) Quartz-epidote veinlets low and calcite-chlorite veinlets higher in the section were precipitated from 
warming descending fluids in a geothermal system. These veins are best developed on fractures, within vesicles, and along margins of diorite intrusions. Phyllic alteration, characterized by quartz-sericite replacement of primary minerals, is localized along northwest trending faults, major fractures, and margins of intrusions. It is well developed in open-space "crackle" breccias in the quartz-feldspar porphyry intrusion. These breccias are cemented with quartz, sphalerite and galena and are related to base-metal veins in the Ruth Mine. Calcite deposition in veins terminated or postdated main stage mineralization. Argillic alteration characterized by kaolinization of hanging-wall breccias and accompanied by the precipitation of fine grained gypsum is the last major alteration noted. It may have developed in response to changes in the groundwater hydrologic system late in or following volcanic activity.

Fluid inclusions in quartz from base-metal veins exhibit low salinities typical of a meteoric origin and homogenization temperatures from $220-295^{\circ} \mathrm{C}$. Inclusions in quartz-epidote veinlets also have low salinities and display homogenization temperatures near the upper end of the range of the base-metal veins. Near the eastern margin of the mineralized area, a vein containing chalcedony deposited alternately with quartz is believed to be within the zone of mixing of hydrothermal solutions and cold groundwater. Homogenization temperatures are consistant with a paleosurface located within those units erupted from the developing volcanic center on French Creek Ridge. 
GEOLOGY AND GEOCHEMISTRY OF HYDROTHERMAL ALTERATION, EASTERN PORTION OF THE NORTH SANTIAM MINING AREA

by

J. MICHAEL POLLOCK

A thesis submitted in partial fulfillment of the requirements for the degree of

\author{
MASTER OF SCIENCE \\ in \\ GEOLOGY
}

Portland State University

1985 
TO THE OFFICE OF GRADUATE STUDIES AND RESEARCH:

The members of the Committee approve the thesis of J. Michael Pollock presented June 12, 1985.

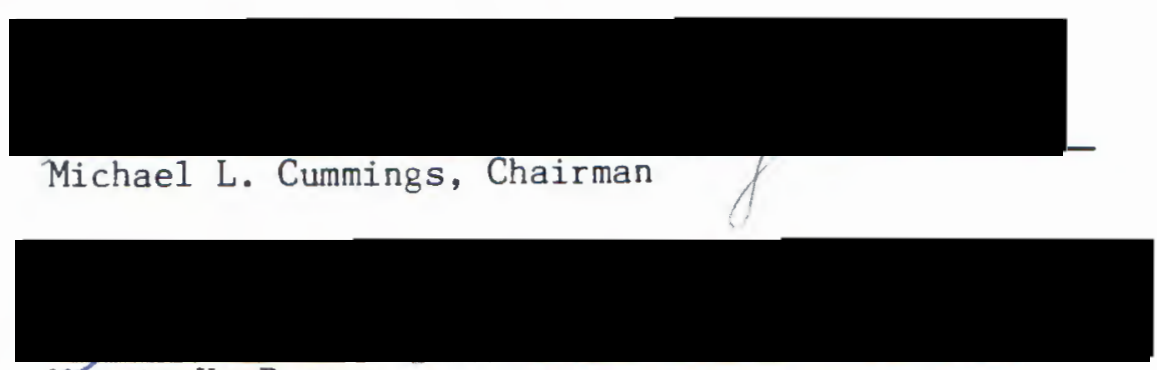

Mărvin H. Beeson

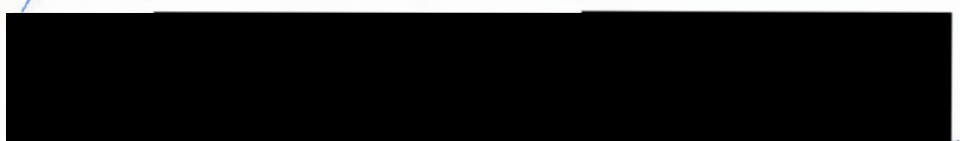

Ansel G. Johngon

APPROVED:

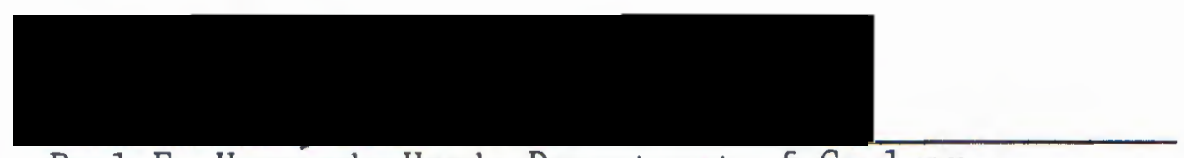

Paul E. Hammond, Head, Department of Geology

Jim F. Heath, Dean of Graduate Studies and Research 


\section{ACKNOWLEDGMENTS}

I would like to thank Shiny Rock Mining Corporation and George Atiyeh, President for their support of the field work for this thesis.

Field assistance was provided by several Portland State University students including Nina Haas, Krista McGowen, Warren Winters, and especially Marilyn Mestrovich and Jack Whalen whose assistance made possible a couple of the longer, more rugged traverses required. Marilyn Mestrovich, Joe Souther, Karen Wilson, and C. Susan Evans provided assistance during the laboratory phase. Mark Neuhause, of the Oregon Department of Geology and Mineral Industries, drafted the map of the mining area.

The understanding support and encouragement of my wife, Barbara Woodhull, has been an essential factor in the completion of this project.

In addition, I would like to acknowledge the assistance and support of the geology faculty and staff at Portland State throughout my graduate studies especially Marvin Beeson, Robert Van Atta, Paul Hammond, Ansel Johnson, and Gene Pierson. Finally and most importantly, this project would never have been accomplished without the consistent support and encouragement of my thesis advisor, Michael L. Cummings. 
TABLE OF CONTENTS

PAGE

ACKNOWLEDGMENTS

LIST OF FIGURES . . . . . . . . . . . . . . . . vii

LIST OF PLATES . . . . . . . . . . . . . . . ix

\section{CHAPTER}

I INTRODUCTION ....................... 1

General ................ . 1

Purpose and Scope.............. 4

Methods ................. 4

Mining History .............. . 4

Access and vegetation ............ 6

II GEOLOGIC SETTING ................ . 7

Stratigraphy ............. . 7

Intrusive Units .............. . 11

Structure .................. 11

Alteration ................ . . 14

III GEOLOGY OF THE RUTH MINE AREA ............ 16

Geomorphology .............. 16

Stratigraphy ............. . 17

Unit A

Unit B

Unit $C$

Unit $D$

Tuffs of uncertain stratigraphic position 
Intrusions . . . . . . . . . . . . . 27

Structure . . . . . . . . . . . . . . 33

IV ALTERATION AND MINERALIZATION . . . . . . . . . . . 36

Alteration types and general distribution . . . . . 36

Alteration of tuffs of Unit A . . . . . . . . 39

Alteration of quartz-feldspar porphyry . . . . . . 44

Description of base-metal veins . . . . . . . . . 44

Distribution of base-metal veins . . . . . . . . 48

Mineralization in the Ruth Mine... . . . . . . 48

Fluid inclusion data . . . . . . . . . 52

V GEOCHEMISTRY . . . . . . . . . . . . . . . . . . . . 54

"Unaltered" stratigraphic units . . . . . . . . . 54

Intrusions . . . . . . . . . . . . . 59

Quartz-feldspar porphyry intrusion

Porphyritic diorite intrusion

Equigranular diorite intrusion

Geochemistry of alteration of a tuff of Unit A . . . 62

VI DISCUSSION . . . . . . . . . . . . . . . . 64

Stratigraphic relationships . . . . . . . . . . 64

Intrusive history . . . . . . . . . . . 70

Structural development . . . . . . . . . . . 71

Alteration and mineralization .. . . . . . . 72

Model .................... . . 75

VII SUMMARY AND CONCLUSIONS . . . . . . . . . . . . . 80 REFERENCES CITED . . . . . . . . . . . . . . . . . . . . . 
Appendix A: Measured sections and traverses . . . . . . 87

Appendix B: Location and description of samples . . . . . 89

Appendix C: Neutron activation analysis data . . . . . 93 


\section{LIST OF FIGURES}

FIGURE

PAGE

1. Location map--North Santiam mining area . . . . . . . . 2

2. North Santiam mining area . . . . . . . . . . . 3

3. Correlation of regional stratigraphic units . . . . . . 8

4. Episodes of deformation previously reported . . . . . . 13

5. Composite columnar section . . . . . . . . . . . 18

6. Photograph of the polymictic breccia of Unit A . . . . . 20

7. Photomicrographs of unaltered flows of Unit B . . . . . 22

8. Fine grained, laminated deposit of Unit C . . . . . . . 24

9. Photomicrographs of flows of Unit D . . . . . . . . . 26

10. Characteristics of the three types of intrusions . . . . . 27

11. Photomicrographs of equigranular diorites . . . . . . 29

12. Photograph of porphyritic diorite dike . . . . . . . 32

13. Photograph of handsample from a quartz-feldspar porphyry . 32

14. Geologic cross-section . . . . . . . . . . . . 34

15. Photograph of main fork of Henness Creek . . . . . . . . 35

16. Calcite-chlorite weinlet in flow of Unit D . . . . . . 37

17. Photomicrographs of altered tuffs from Unit A . . . . . 41

18. Alteration mineralogies--Tuff of Unit A . . . . . . . 43

19. Photomicrographs of quartz-feldspar porphyry . . . . . 45

20. Photograph of vein sample from the Morning Star mine . . 46

21. Pargenetic sequence for mineralization . . . . . . . 46

22. Photograph of thin-section from quartz-chalcedony vein . . 47

23. Ore textures from base-metal veins........... . 49 
24. Sketch of a low-angle vein . . . . . . . . . . . 51

25. Fluid inclusion data . . . . . . . . . . . . . 53

26. Plots of iron ( $\mathrm{Fe}$ ) and Scandium ( $\mathrm{Sc}$ ) against sodium ( $\mathrm{Na}$ )

for rocks in the stratigraphic sequence . . . . . . 56

27. Plots of the incompatable elements lanthanim ( $\mathrm{La}$ ) and hafnium (Hf) against thorium (Th) . . . . . . . 57

28. Rare-earth elements plotted against chondrite--Flows of Units B and D . . . . . . . . . . . . . 58

29. Rare-earth elements plotted against chondrite--Tuffs and Quartz-feldspar porphyry intrusions . . . . . . . 60

30. Rare-earth elements plotted against chondrite--Diorite intrusions . . . . . . . . . . . . . . . . .

31. Rare-earth elements plotted against chondrite--Altered tuffs of Unit A and vein clays . . . . . . . . . .

32. Correlations with previous small-scale mapping . . . . 66

33. Summary . . . . . . . . . . . . . . . 76

34. Model ...................... . . 77

35. Boiling point vs. depth to paleosurface . . . . . . . 79 


\section{LIST OF PLATES}

PLATE

I. Geologic map--eastern portion, North Santiam mining area.

II. Detailed geologic map--Battle Ax Creek, Sections 27 and 28.

III. Ruth Mine, 5th level, North Santiam mining area. 


\section{CHAPTER I}

\section{INTRODUCTION}

\section{Genera1}

While it has been postulated for some time that porphyry copper mineralization develops within subduction related stratovolcanos (Sillitoe, 1973; Henley and Ellis, 1983), little is known about those portions of the system between the magmatically dominated mineralized core and the surface existing at the time of mineralization. Questions such as the nature of fluid movement in the volcanic pile, timing of porphyry mineralization relative to the volcanic activity, timing of the development of alteration relative to porphyry and vein mineralization, and the presence of surface geothermal expression, if any, are open for evaluation.

The North Santiam mining area is located near the headwaters of the Little North Santiam River (Figure 1). Metal mineralization in the district is centered on a set of intrusions with which are associated tourmaline bearing breccia pipes (Figure 2) and disseminated chalcopyrite (01son, 1978) typical of a porphyry copper deposit. Uplift of the Western Cascade Range relative to the High Cascade Range which began approximately 5-4 m.y. B.P. (Priest and others, 1983) has resulted in a deeply dissected terrain in which more than a kilometer of the stratigraphy overlying the mineralization is preserved and exposed. 


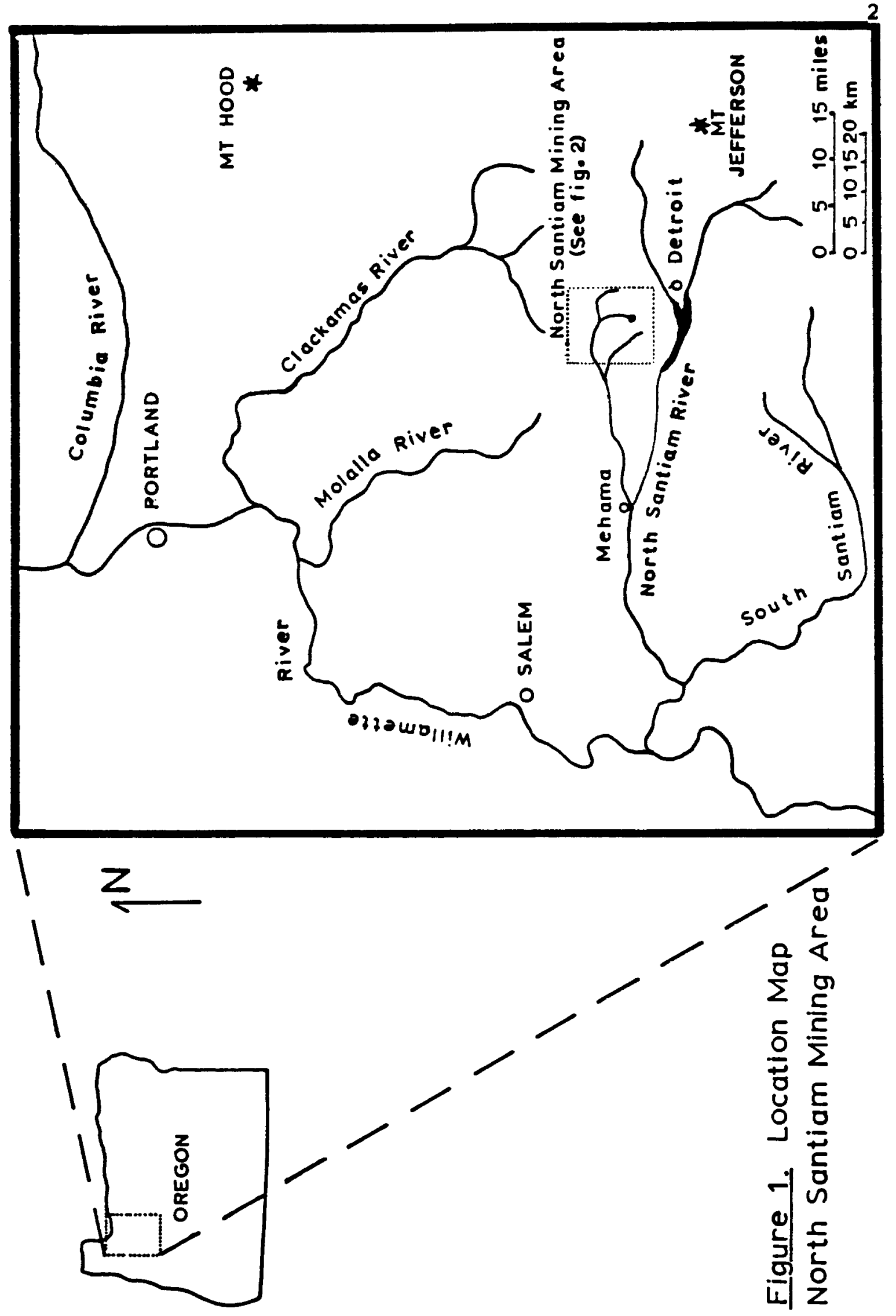




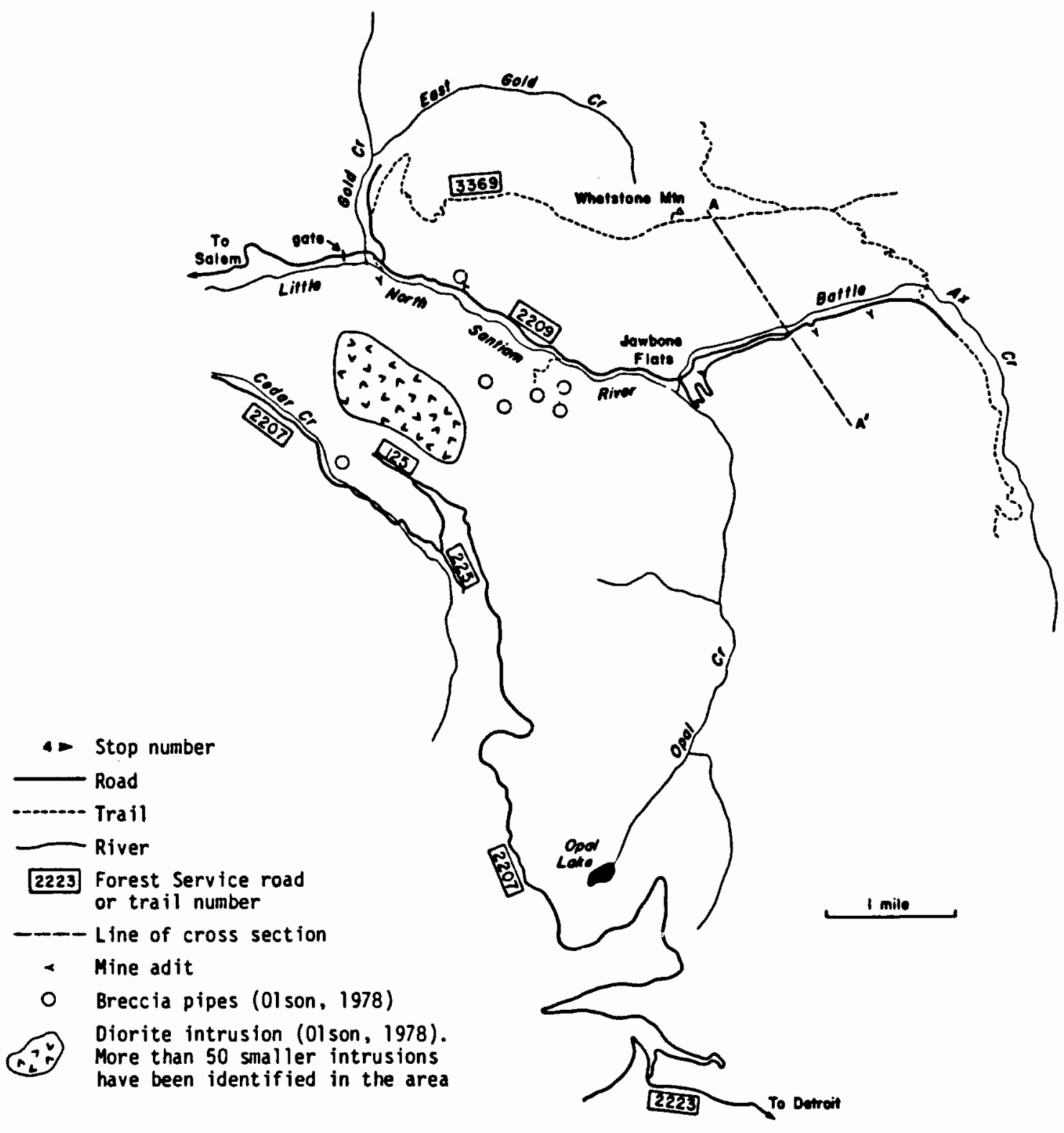

Figure 2. North Santiam mining area 
Purpose and Scope

The purpose of the current study is to 1) define alteration mineralogy and distribution of alteration zones relative to structures and stratigraphy; 2) define the volcanic stratigraphy and intrusions; 3) determine the mineralization and alteration history of the Ruth Mine and where possible, other mineralized areas; 4) determine the geochemistry of alteration and 5) conduct a preliminary analysis of the origin and composition of ore forming solutions. Models are proposed and discussed for the formation of the observed alteration system and for the nature of the paleosurface developing at the time of mineralization.

\section{Methods}

Field mapping of all or portions of sections $26,27,28,33,34$, and $35, \mathrm{~T} 8 \mathrm{~S}, \mathrm{R} 5 \mathrm{E}$, has been completed with a focus on the alteration system. The geochemistry of several alteration zones has been determined by neutron activation analysis. Fluid inclusion data has been obtained on several of the veins.

Mining History

The North Santiam Mining area is one of five mining districts located in the Western Cascades of Oregon. The general geology of these districts and an overview of their mineralization contained therein, were presented by Callaghan and Buddington (1938). Descriptions of current and abandoned workings were prepared by the Oregon Department of Geology and Mineral Industries (1951). A summary of the districts was also prepared by Mason and others (1977). From south to north these 
districts include Bohemia (Lutton, 1962; Gray and Vogt, 1978; Gray, 1978; Istas, 1982), Fall Creek (Gray and Berri, 1983), Blue River (Storch, 1978), Quartzville (Gray, 1977; Munts, 1978), and the North Santiam (01son, 1978). Production from veins containing base metals and gold has been reported from these districts (Oregon Department of Geology and Mineral Industries, 1951; Brooks and Ramp, 1968).

Exploration for gold in the North Santiam mining area dates back to the 1860's (George, 1985). In the early part of this century, the Ruth Vein was discovered near the eastern end of the mining district (Figure 2) and has been the focus of mining efforts for zinc and lead periodically since. The name, North Santiam mining area, was applied by Callaghan and Buddington (1938) to all the mineral claims along the North Santiam River and its tributaries in their evaluation of the Western Cascade mining districts. However, the claims surrounding the Ruth Vein were previously known as the Lester Mining District (George, 1985). The claims associated with the Lester Mining District are held by the Shiny Rock Mining Company. Jawbone Flats is the mill site and operational headquarters for the claim block.

Recent exploration in the North Santiam Mining Area has focused on the potential of the porphyry copper mineralization in the central portion of the mining area. Reconnaissance mapping, geological chip sampling, and drilling of two holes totalling $1255 \mathrm{~m}(4118 \mathrm{ft})$ was performed from 1976-1978 by Freeport Exploration Company under lease agreement with Shiny Rock Mining Company (Decker and Jones, 1977). Amoco Minerals Company optioned the Shiny Rock Mining Company claim block beginning in 1980 and conducted additional field mapping, soil 
geochemistry, an induced polarization-resistivity survey and additional drilling. Ten core holes totalling $1518 \mathrm{~m}$ (4979 ft) were drilled during 1981-1982 (Dodd and Schmidt, 1982). Amoco Minerals continues to hold claims, primarily along Cedar Creek, west and south of the Shiny Rock Mining Company claims. Drilling has been conducted, especially at a breccia pipe located along Cedar Creek in Section 36, T 8 S, R 4 E.

\section{Access and vegetation}

The study area is heavily vegetated. Two main plant ecosystems are represented. Old growth Douglas-fir and hemlock with an understory of rhododendron and bear grass are found as the dominant species in drier areas; Douglas-fir, cedar, and hemlock with an understory of vine maple, sword fern, Oregon grape and salal dominate in wetter areas (Siddal1, oral communication, 1985). The portion north of Battle Ax Creek was incorporated into the Hidden Wilderness Area by act of Congress in 1984 .

Mining Claims in the study area are held by the Shiny Rock Mining Company which has made their facilities available for this study.

Under the auspices of Shiny Rock Mining Company, the history of the district has been researched (George, 1985) and an attempt has been made to identify original names of geographic features used during the early mining history of the district. Names used in this report are consistant with this effort unless this would result in a conflict with officially designated geographic names.

This study is part of a proposed ongoing evaluation of detailed stratigraphy and alteration geochemistry in the area. 


\section{CHAPTER II}

\section{GEOLOGIC SETTING}

\section{Stratigraphy}

Stratigraphic relationships in the Western Cascades are complicated by the nature of subaerial volcanism as well as by a multiplicity of names and interpretations proposed by various researchers. A correlation chart is presented in Figure 3 in an attempt to simplify the discussion of the regional stratigraphy.

The strata exposed along the Little North Santiam River are those of the Sardine Series of Thayer (1936) as extended by Peck and others (1964). Thayer originally described this series as consisting of about $1800 \mathrm{~m}(6,000 \mathrm{ft})$ of "basaltic to dacitic lavas". The type locality of the Sardine Series was defined at Sardine Mountain located northwest of Detroit. The type locality was subsequently described by Thayer (1939) as consisting of $1200 \mathrm{~m}(4,000 \mathrm{ft})$ of lavas, tuffs, and breccias. The lavas were reported to be "chiefly andesites although they range from rhyolite to basalt, and (lavas) greatly predominate over tuff and breccia". Peck and others (1964) report the Sardine Formation between the Little North Santiam and the Sandy Rivers as comprising two units, the lower, 300 to $600 \mathrm{~m}(1,000$ to $2,000 \mathrm{ft})$ thick, of primarily fragmental andesites and an upper unit, of approximately the same thickness, of hypersthene andesite flows. 01son (1978) concurred by assigning the rocks of the mining area to the Sardine Formation. He 


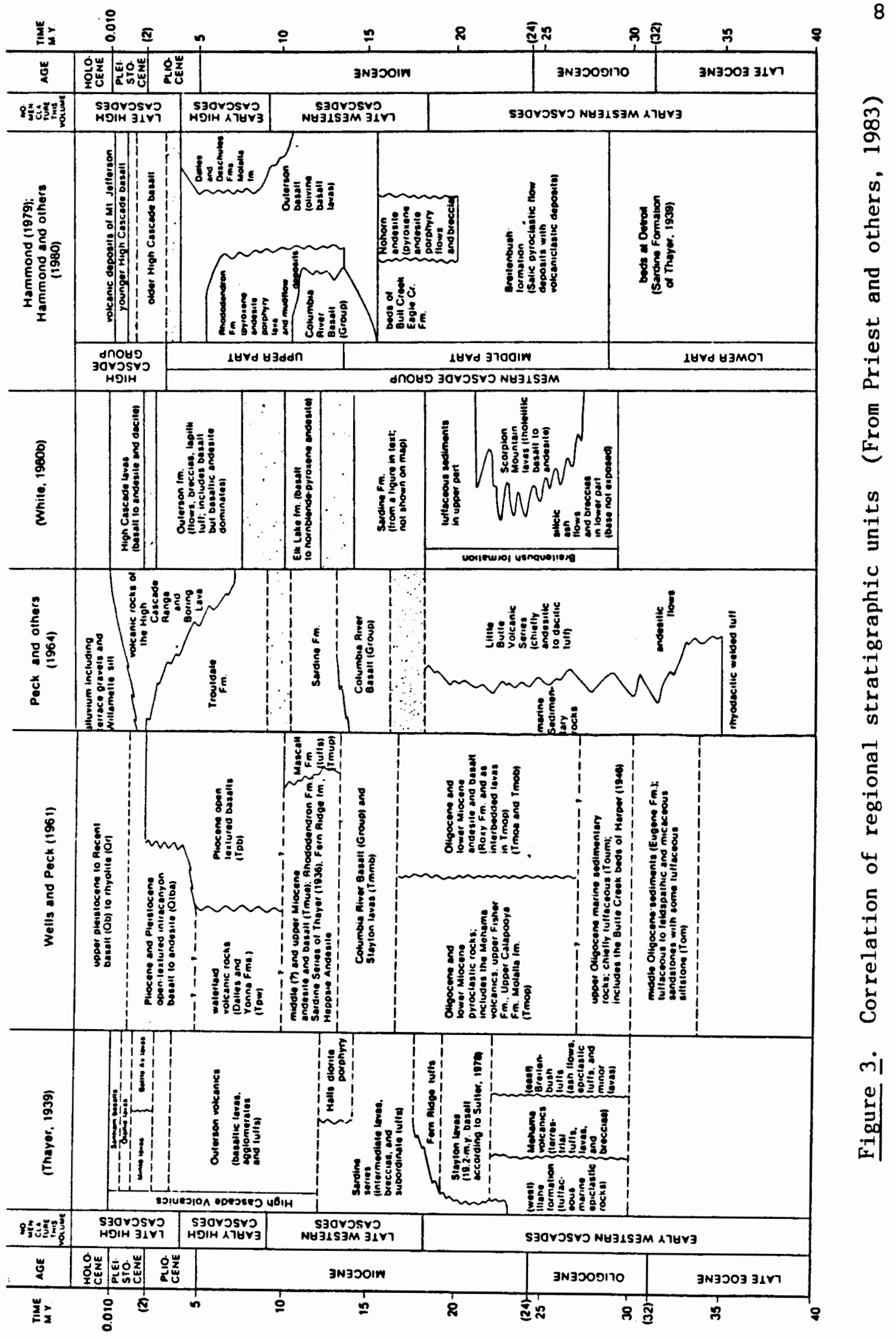


divided the sequence into a lower member consisting of $98 \%$ flows with the remainder mudflows and breccias, and an upper member consisting of andesite flows with interbedded volcaniclastic units. The contact between these members is mapped at elevations between 850 and $1100 \mathrm{~m}$. According to Thayer (1939) the total thickness of the series is exposed along the east limb of the Sardine Syncline east of Detroit where the abundance of tuffs increases in the lower portion of the series and grades downward into the Breitenbush tuffs. The stratigraphic relations in the Detroit area are not clear since different workers have named the same rocks by different names and assigned them to differing stratigraphic positions. Thayer (1939) defined the type section of the Breitenbush tuff along the Breitenbush River between French and Fox Creeks where it consists of about $2300 \mathrm{~m}$ $(7,500 \mathrm{ft})$ of water worked, subaerial tuffs, breccias and conglomerates interlayered with minor flows. However, the contact between the Sardine Series of Thayer and the Breitenbush tuff of Thayer has been argued by White (1980a), and Hammond and others (1982) to be a fault relation. Hammond and others (1982) mapped the area of the type locality for the Breitenbush tuffs as well as the type section of the Sardine Series of Thayer (1939) as part of the beds at Detroit. Hammond and others (1982) indicated that the beds at Detroit are older than the Breitenbush tuff and placed the beds at Detroit in the Lower Western Cascade Group and the Breitenbush tuff in the Middle Western Cascade Group. White (1980a) placed the Sardine Formation stratigraphically above the Breitenbush Formation. Priest and others (1983) attempted to resolve the issue of the stratigraphic relations between the two units, however, additional 
field mapping and analysis will need to be completed in order to finally resolve this controversy (Priest, oral communication, 1985).

The area north of the current study area was mapped by Dyhrman (1976). Volcaniclastic rocks on Whetstone Mountain were named the Whetstone Mountain volcaniclastic rocks and were reported to be underlain in succession by the Thunder Mountain andesite, the Silver King andesite, and the Blister Creek tuff. The Blister Creek tuff was correlated by Dyhrman with the Little Butte Volcanic Series of Thayer (1939); the other units with the Sardine Series as mapped by Peck and others (1964).

White (1980b) studied east and south of the North Santiam study area. White and McBirney (1979) defined the Elk Lake Formation for exposures in the E1k Lake area southeast of the mining area. They placed the Elk Lake Formation as overlying and separated from the Sardine Formation across an angular unconformity. Hither to the rocks of the Elk Lake Formation had been included within the Sardine Formation after Peck and others (1964) and We11s and Peck (1961).

The basalt of Battle Ax volcano unconformably overlies all stratigraphic units in the area. White (1980b) indicated that the volcano developed over a dissected surface on which up to $900 \mathrm{~m}(3,000$ $f t$ ) of local relief was present. The basalts of Battle Ax volcano were erupted during the late High Cascade episode as defined by Priest and others (1983). These basalts have been dated at between 2 and 1 m.y. B.P. (White, 1980b). 


\section{Intrusive units}

Numerous plugs and dikes which apparently served as feeders for the middle and late Miocene volcanics of the Western Cascades have been reported (Thayer, 1939; Peck and others, 1964; White, 1980a). Compositions range from andesite or diorite to quartz monzonite and granodiorite. The center of volcanism for the Sardine Formation is interpreted by Peck and others (1964) to be between the Middle Santiam River and the Collawash River based on the frequency of intrusions, the high percentage of flows, and the thickness of the formation. This area includes the North Santiam mining area where numerous intrusions are present. Originally all intrusions in the mining area were reported as dioritic (Callaghan and Buddington, 1938). 0lson (1978) mapped many of these intrusions and divided them into 7 units ranging in composition from basaltic andesite to quartz latite/rhyodacite. He interpreted the youngest unit to be a granodiorite typified by the large intrusion near the center of the mining area (section 32, T. 8 S., R. 5 E.) and represented in the vicinity of the Ruth Mine by narrow, northwest trending dikes. A $\mathrm{K}-\mathrm{Ar}$ age for a hornblende separate from the large intrusion was reported as $13.4+/-0.9 \mathrm{~m} . \mathrm{y}$. (Power and others, 1981a).

\section{Structure}

Rocks of the Western Cascades are gently folded into a series of northeast-trending anticlines and synclines. Thayer (1939) mapped the Sardine syncline with a N. $25^{\circ}$ E. axis through the Hall's Diorite Porphyry (Detroit pluton), which is about $13 \mathrm{~km}$ south of Jawbone Flats, and continuing to the northern edge of his map area on French Creek 
Ridge. Projection of this trend northeastward approximately $4 \mathrm{~km}$ intersects the southeast corner of the current study area. The Mehama anticline was mapped by Thayer as parallel to the Sardine syncline and approximately $13 \mathrm{~km}$ to the west. Thus the mining area lies between the extensions of the Mehama anticline and the Sardine syncline. Callaghan and Buddington (1938) reported dips north of the Little North Santiam River with a dominant northerly component whereas those south of the river were reported to be dominantly southerly dipping suggesting that the valley of the Little North Santiam River is near the crest of an anticline.

The age of northeast-trending fold structures was estimated to be between 15 and 11 million years by White (1980b) based on K-Ar dating of rocks of the Sardine Formation and the E1k Lake Formation about $8 \mathrm{~km}$ southeast of the Ruth Mine.

The orientation and timing of faulting in the Cascade Range has been summarized by Priest and others (1983) and is shown in Figure 4 from their report. Priest and others (1983) concluded that northeasttrending faults accompanied folding during the late Western Cascade period from 16 to $10 \mathrm{~m} . \mathrm{y}$. B.P. Normal faults and intrusions with trends of $N .20^{\circ}-40^{\circ} \mathrm{W}$. preceed and accompany regional uplift of the Western Cascades relative to the High Cascades which began 5 to $4 \mathrm{~m} . \mathrm{y}$. B.P. Northwest-trending lateral faulting spans a much longer time from 15 to $2 \mathrm{~m} . \mathrm{y}$. B.P. North-northwest to north-south faulting associated with graben development began in the central Oregon Cascades as early as $18 \mathrm{~m} . \mathrm{y}$. B.P. but has been active in the Breitenbush-Clackamas River areas only since about 5 m.y. B.P. (Priest and others, 1983). 


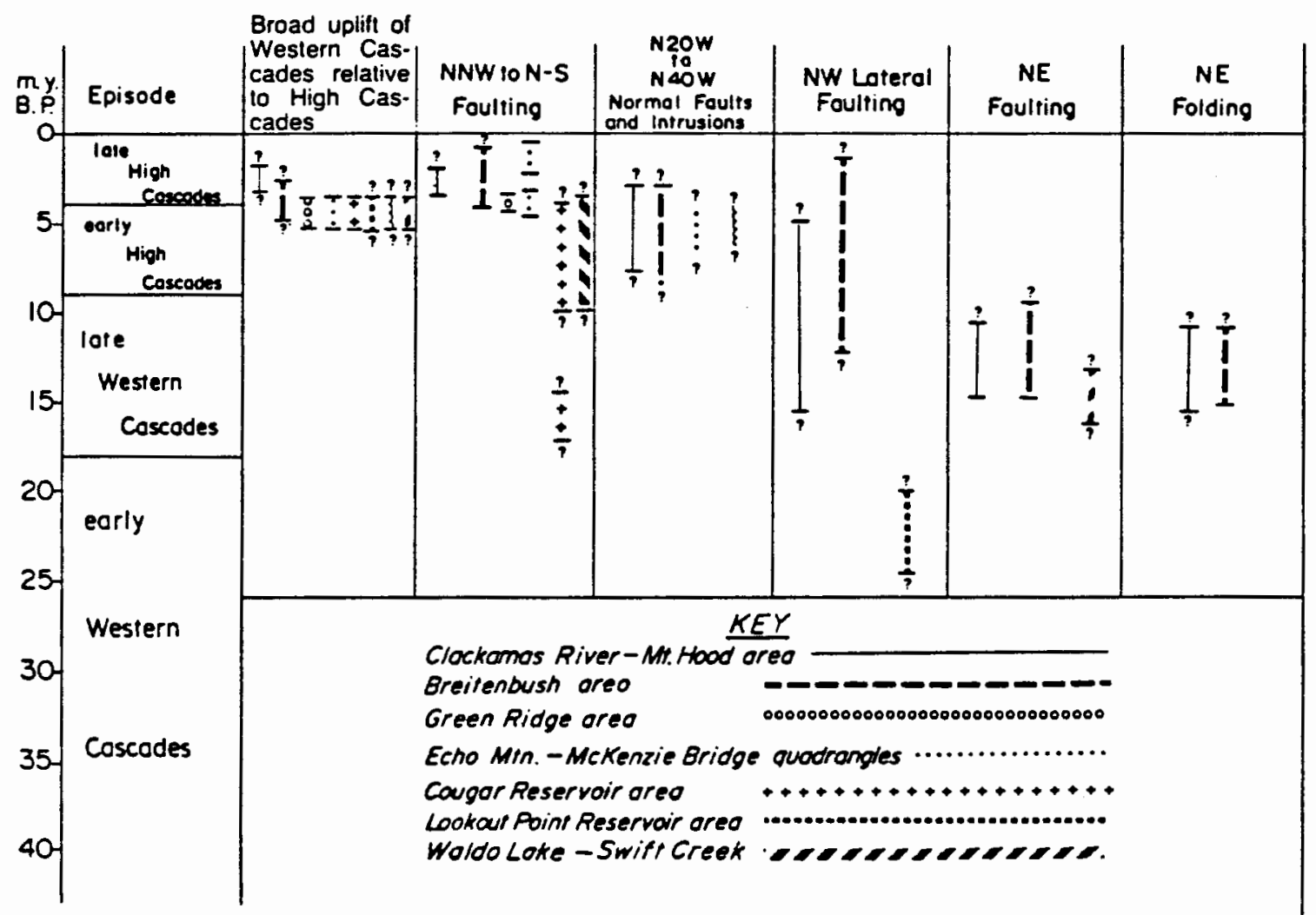

Figure 4. Episodes of deformation previously reported in some mapped areas of the northern and central Cascades. From Priest and others (1983) based on Hales (1975), Hammond and others (1980), Taylor (1980), White (1980b), Avaramenko (1981), Flaherty (1981), and Priest and others (1983).

\section{Alteration}

Most of the volcanic rocks of the Western Cascade Range that are Miocene or older have been subjected to some form of alteration (Peck and others, 1964). Propylitic alteration is found in discontinuous areas throughout the Western Cascades in Oregon (Peck and others, 1964). These areas of propylitic alteration lie in a generally north-south line near the boundary between the Western and High Cascade provinces. Outside the zones of propylitic alteration, pyroclastic rocks of the Western Cascades are thoroughly altered. Glass is completely replaced by zeolites and a green clay which is often associated with chalcedonic 
silica, cristobalite or opal, and carbonate. The green clay is reported to consist of combinations of celadonite and montmorillonite (Peck and others, 1964).

Within the North Santiam Mining area, O1son (1978) identified a zoned alteration system centered in the eastern half of section 29 , T. 8 S., R. 5 E. This zoned system has a central potassium silicate zone containing an alteration assemblage of biotite, quartz, sericite, kaolinite, and small quantities of potassium feldspar. Biotite, interpreted as replacing hornblende and augite, has been subjected to retrograde alteration to chlorite. Olson (1978) mapped a phyllic alteration zone consisting of an assemblage of quartz, sericite and kaolinite surrounding the potassic zone. He notes that the phyllic alteration is strongly controlled by structures with the most extensive alteration along and adjacent to northwest-trending shears. Within this phyllic zone, tourmaline is found in breccias and is associated with quartz and sericite. 01son interpreted the geometry of these breccias to be "pipe-1ike". A whole rock age date in one of these breccias was reported as $11.0+/-0.4$ m.y. B.P. (Power and others, 1981b). Outside of the mapped phyllic zone, 0lson reported pervasive propylitic alteration assemblages of chlorite, epidote, carbonate, and quartz extending well beyond the boundaries of the mining area and grading imperceptably into unaltered rocks. The presence of breccia pipes, and zoned alteration, together with zoned mineralization from predominantely chalcopyrite/bornite outward to chalcopyrite/pyrite to base metals (Callaghan and Buddington, 1938; 01son, 1978) led 01son to propose a porphyry copper model for the area. 
Taylor (1971) has examined oxygen isotope ratios of several Tertiary intrusions in the Western Cascades including the Bohemia Mining District and the unmineralized Detroit pluton which is located $13 \mathrm{~km}$ south of the North Santiam Mining area. Both country rocks and intrusions are reported to be depleted in $18_{0}$ suggesting strong meteoric-hydrothermal systems were involved in the alteration. 
CHAPTER III

GEOLOGY OF THE RUTH MINE AREA

The geology of the Ruth Mine area was mapped during the summers of 1983 and 1984 and is shown in Plates I and II. The relations among mineralized veins, structures, and intrusions relative to patterns in hydrothermal alteration and stratigraphy were the foci of field mapping. All place locations in this text are for sections within township 8 south, range 5 east, Willamette Meridian.

\section{Geomorphology}

The elevation of Battle Ax Creek on the western edge of the mapped area is about $640 \mathrm{~m}(2100 \mathrm{ft})$ while the top of Whetstone Mountain, about $1600 \mathrm{~m}$ to the north, is $1520 \mathrm{~m}$ (4980 ft). Those tributaries of Battle Ax Creek to the south are deeply incised in narrow canyons 30-50 meters deep especially in several places along Opal and Henness Creeks, whereas those tributaries of similar size north of Battle Ax Creek are much less incised. Numerous waterfalls up to 10 meters in height are found on Battle $\mathrm{Ax}$ and Opal Creeks and significantly higher falls are found on the smaller tributaries.

Two cirques are present on the eastern side of the north-south trending ridge in sections 27 and 35 , with a third found at the head of Flume Creek. Glacial scour was noted to elevations of at least $1340 \mathrm{~m}$ $(4400 \mathrm{ft}$ ) on Whetstone Mountain. Glacial deposits, which were not 
mapped during the present study are found throughout the area but are especially common at lower elevations in the valley of Battle Ax Creek in sections 26 and 35 .

\section{Stratigraphy}

The stratigraphic units in this study have been given arbitrary letter designations beginning with the lowest unit (Unit A) through the uppermost unit (unit D). A generalized columnar section is shown in Figure 5. Measured sections from which the units were defined are found in Appendix A. The locations of these measured sections are shown on Plates I and II.

\section{Unit $\underline{A}$}

Unit A is comprised of fragmental rocks of andesitic composition. All tuffs in Unit A are moderately to extensively altered. Lapilli tuffs are generally medium to dark green in color, however with increasing alteration, their clastic textures are obscured and they are easily mistaken for porphyitic andesite flows. In zones of intense alteration, they may be "bleached" to a white color and primary textures are completely destroyed.

The lowest member of this stratigraphic unit in the mapped area (Figure 5), is a distinctive polymictic breccia previously described by 0lson (1978). Wherever it is exposed in the study area it is moderately to extensively altered, and well-indurated. It forms distinctive outcrops in the stream beds characterized by narrow, deep "pot-holes" or long, narrow "chutes". 


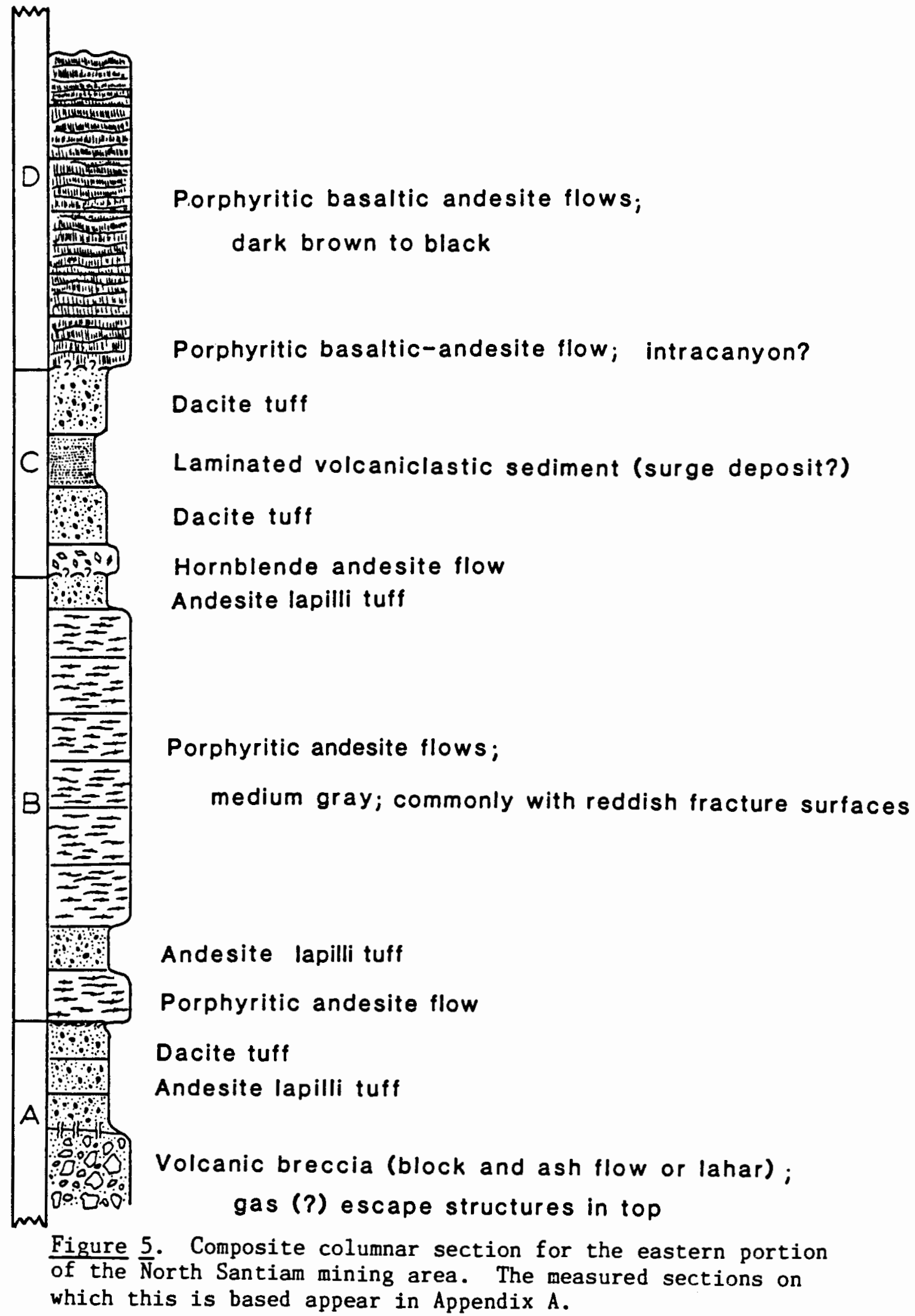


This breccia is unsorted and matrix-supported, containing clasts ranging in size from less than $0.5 \mathrm{~cm}$ to $2 \mathrm{~m}$ or more in diameter. Clasts are subangular to moderately well-rounded. Three distinctly different types of clasts are present. Two of these types contain abundant opaque phases in their groundmass and, upon alteration, their color is dark reddish gray; one is porphyritic, containing both plagioclase and mafic phenocrysts, the other is non-porphyritic. The third type of clast is also porphyritic but lacks abundant opaques and, where altered, it forms a light greenish gray clay. The matrix consists of ash size ( $<4 \mathrm{~mm})$ lithic fragments of the same three fragment types, feldspar crystal fragments and extremely fine grained feldspar grains, clays, and finely crystalline materials. The upper contact is sharp against a lapilli tuff; the base is not exposed.

Exposed at several locations along Battle Ax and Opal Creeks are parallel-sided, steeply dipping zones in which clasts and matrix are sorted (Figure 6). They are from $2 \mathrm{~cm}$ to $10 \mathrm{~cm}$ wide, exceed $5 \mathrm{~m}$ in length, and contain predominantly gravel size, rounded clasts. These zones cut the polymictic breccia but display no common orientation and irregular, often erratic trends. In several exposures, these structures are continuous across the contact and penetrate the lower 3-5 $\mathrm{m}$ of the overlying lapilli tuff.

Exposures of this breccia are found in the stream beds of the Little North Santiam River, Opal Creek, and Battle Ax Creek in sections 28,27 , and 33 and continue into section 29 beyond the mapped area. Overlying the polymictic breccia and forming the bulk of Unit $A$ is a sequence of andesitic lapilli tuffs. The thickness of individual 


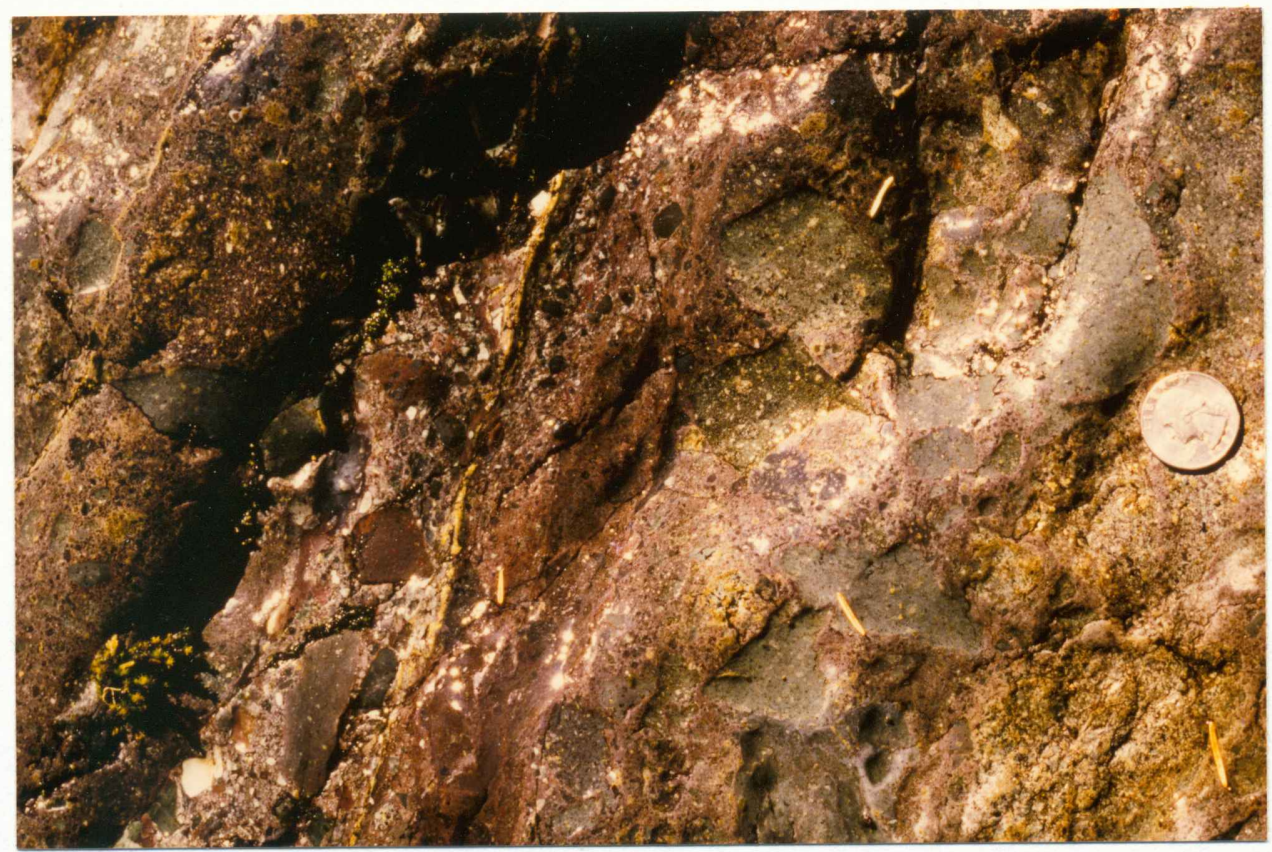

Figure 6 . Photograph of the polymictic breccia of Unit A. Note the zone of sorted clasts which crosses the photo from top to bottom in an otherwise unsorted matrix.

cooling units is not readily determined due to alteration and sparse exposures of contacts. Outcrop heights and separations suggest that the thicknesses range from 10-50 meters. The fine grained tuff which overlies the polymictic breccia has a thickness of about $25-30 \mathrm{~m}$.

Clasts greater than $32 \mathrm{~mm}$ in diameter are uncommon. Lapilli-size lithic fragments are of the same three types as the clasts in the polymictic breccia. No fresh glass is apparent in these samples although, from textures observed in thin section, it is postulated as an original component of much of the groundmass. Flattened lapilli and pumice fragments are present in some of the tuffs suggesting that some were welded at least through part of their thickness. 


\section{$\underline{\text { Unit }} \underline{B}$}

Overlying and interlayered with the lapilli tuffs is a sequence of porphyritic andesite flows. Phenocrysts of plagioclase feldspar and pyroxene are present in an aphanitic groundmass. These textures are illustrated in photomicrographs in Figure 7. Oriented plagioclase microlites in many samples suggest flow texture. Clinopyroxene dominates over orthopyroxene. Quartz and hornblende are absent in samples examined although the presence of rare early formed amphibole is suggested by masses of opaques outlining relict phenocrysts.

The flows are medium gray in color and display platy to blocky fractures. Fracture surfaces are comnonly reddish brown in color and masses of reddish brown hematite may be present in the groundmass.

For mapping purposes, the base of Unit $B$ has been defined as the first occurrence of a flow of unit $B$ while the top is the last occurrence. The identified distribution of the flows of unit $B$ is shown in Appendix A and on Plate I. The best continuous exposure of these flows is along the main fork of Hennesse Creek where a single tuff of Unit $A$ is found to overlie the first flow of Unit $B$.

The lowest flow within this sequence contains large (to $3 \mathrm{~cm}$ ) glomerocrysts of plagioclase. South of Battle Ax Creek this flow overlies a layer of bedded fine grained stream deposits 0.5 to $1 \mathrm{~m}$ thick. The best exposures of this contact are near the adit of the Morning Star Mine and along traverse B-35 (Appendix A and Plate I). The flow is brecciated in its base and has baked the underlying sediments. The apparent dip of this contact in section 35 is $6^{\circ}$ to the south. Flow contacts commonly display reddish baked zones. 

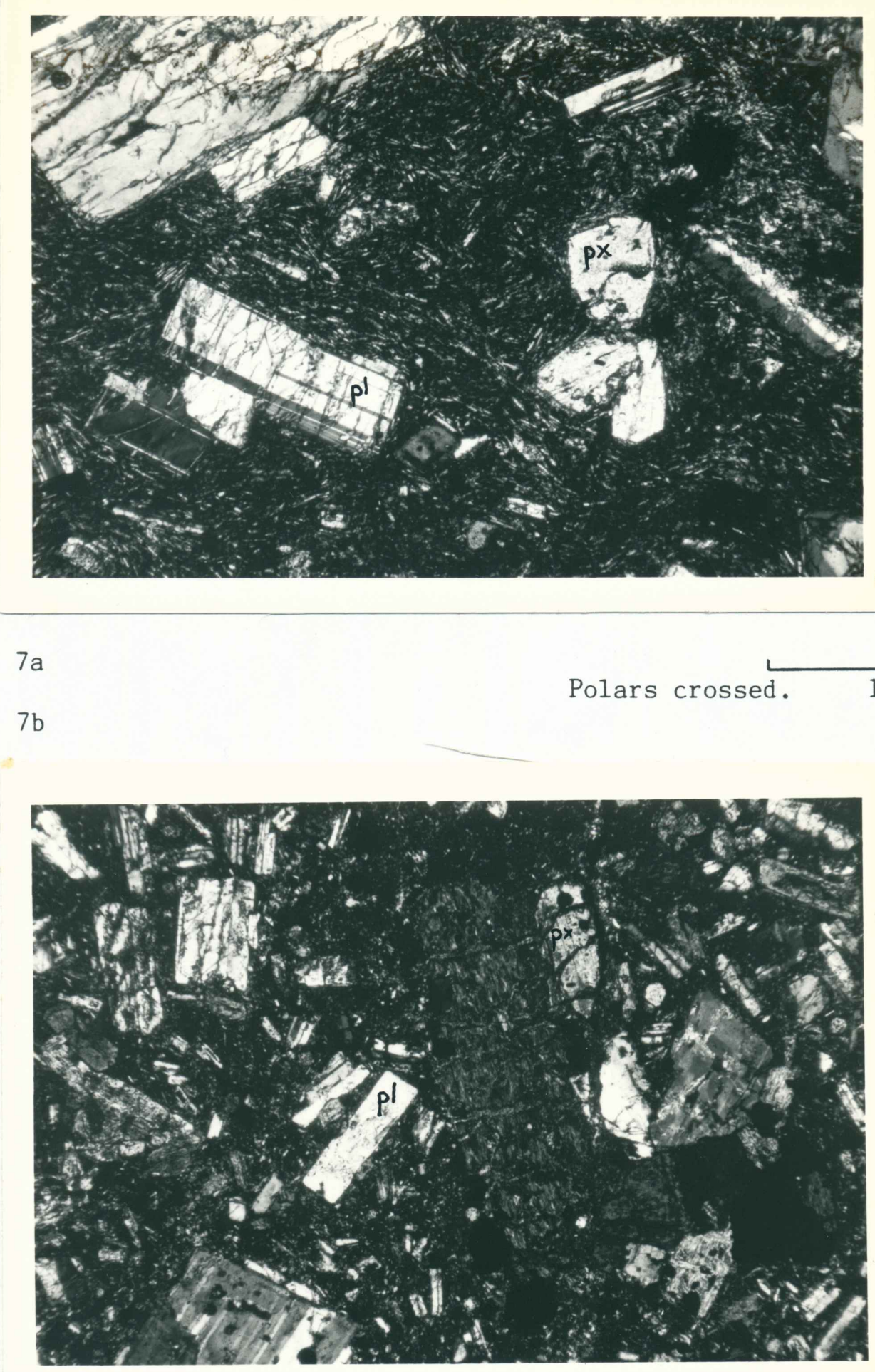

Figure 7. Photomicrographs of unaltered flows of Unit B. Rocks are porphyritic with plagioclase (p1) and pyroxene (px) phenocrysts. Note the orientation of microlites in Figure 7a from a sample (RD-27-34) collected along Henness Creek. Figure $7 \mathrm{~b}$ is from Whetstone Mountain (WM-6). 


\section{$\underline{\text { Unit }} \underline{\mathrm{C}}$}

Unit $C$ consists of a sequence of tuffs varying from andesitic to dacitic in composition. South of Battle Ax Creek, the lower tuffs resemble the tuffs of Unit A. On Whetstone Mountain they contain smaller lithic clasts and a greater percentage of crystal fragments. Within Unit C on Whetstone Mountain is a 20-25 m thick, distinctly laminated, fine grained deposit (Figure 8). At an elevation of $1400 \mathrm{~m}(4580 \mathrm{ft})$, this deposit directly overlies a very well indurated dacite or rhyolite tuff containing flattened pumice. The rocks display parallel, 1 to $5 \mathrm{~mm}$ thick laminations of alternating light and dark colored materials. Individual laminae may be traced for more than 10 meters along the outcrop face. Where a rounded, $50 \mathrm{~cm}$ diameter clast is encountered, the laminae override the clast and are absent on its north side (Figure $8 \mathrm{a}$ ). The rocks form cliffs where they contain hydrothermally introduced carbonate. Locally abundant carbonized plant fragments are found low in the unit (Figure $8 \mathrm{~b}$ ). Fragments include twigs up to $5 \mathrm{~cm}$ in length, needles, and possible seed pods. A strong lineation in these fragments is commonly noted, however, the orientation among layers varies. Where this laminated deposit is not strongly indurated, the resulting creep produces distorted tree growth in the old-growth timber. This deposit has only been detected on Whetstone Mountain although there is a distinct receeding topographic bench at this stratigraphic position throughout the area south of Battle Ax Creek suggesting that it is present. 


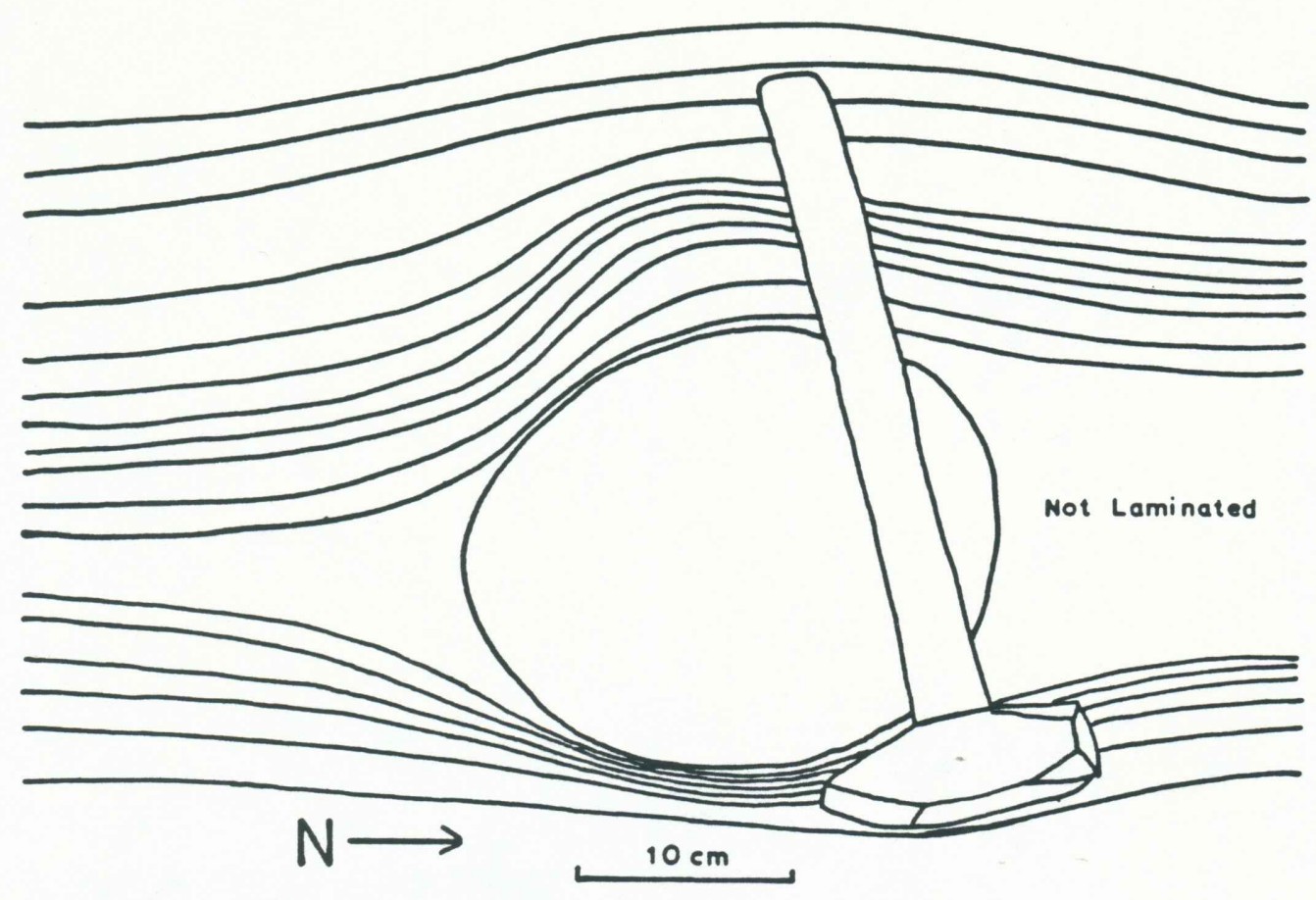

$8 a$.

$8 \mathrm{~b}$.

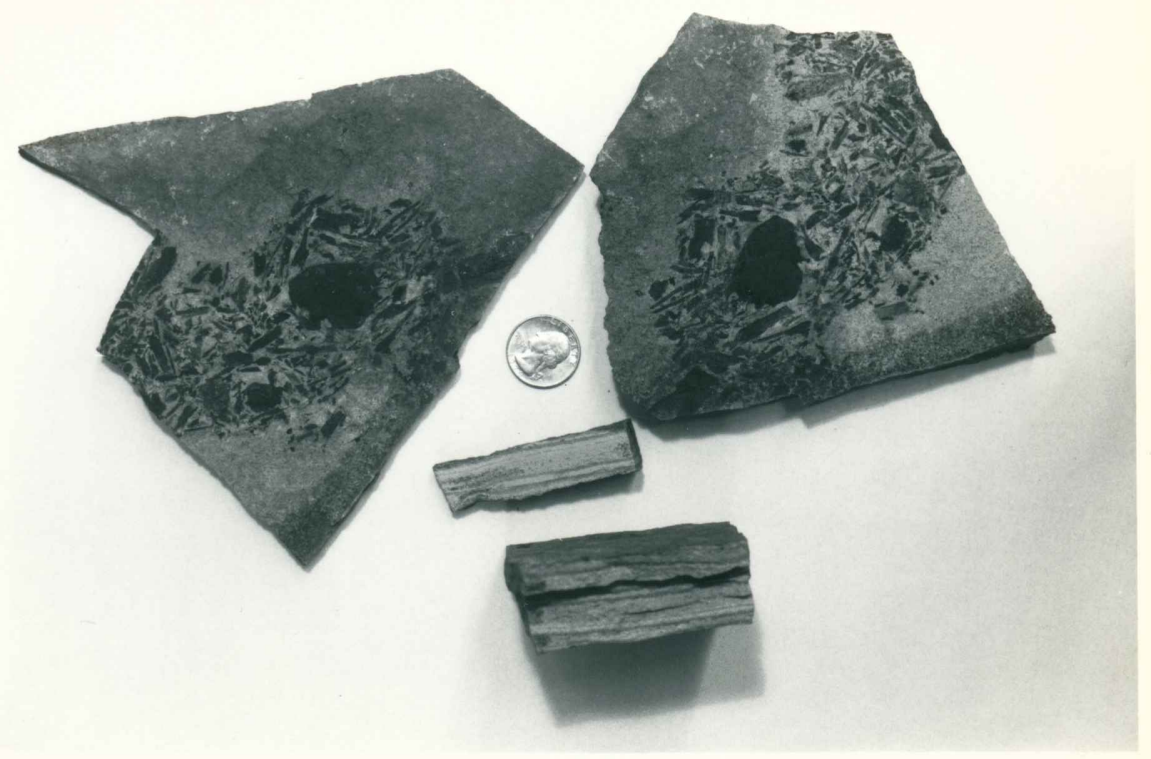

Figure 8. Fine grained, laminated deposit of Unit $\mathrm{C}$ on Whetstone Mountain. The sketch (Figure 8a) shows the relationship between the laminations and a $50 \mathrm{~cm}$ rounded clast deposited within it. Locally abundant carbonized plant fragments present low in the unit are shown in Figure $8 \mathrm{~b}$. 


\section{$\underline{\text { Unit }} \underline{\mathrm{D}}$}

Unit D consists of dark brown to black, porphyritic basalts and basaltic andesites. They contain phenocrysts of plagioclase and some are glomerophyric. Abundant lath-shaped pyroxene phenocrysts to $2 \mathrm{~cm}$ in length are also present (Figure 9). Orthopyroxene is the dominant pyroxene and is commonly partially to completely uralitized while subordinate augite is fresh. Plagioclase anorthite contents range from $55-62 \%$. The characteristic color is attributed to groundmass opaques.

Capping Whetstone Mountain above an elevation of $1480 \mathrm{~m}(4,850 \mathrm{ft})$ are two flows of Unit $D$, each $12-15$ m thick. Flows of Unit $D$ are found above an elevation of $1040 \mathrm{~m}(3,400 \mathrm{ft})$ south of Battle Ax Creek.

\section{Tuffs of uncertain stratigraphic position}

Light brown dacitic crystal tuffs containing quartz crystals have been identified at two locations within the mapped area (Samples WM-3 and $W-28-16 a$, Appendix $B)$. One of these (WM-3) is found on Whetstone Mountain near the top of Unit A, while the other was identified on McCarver Creek near the base of Unit C. The relationship of these tuffs to the stratigraphic units in which they are found is uncertain. They are distinctive in both handsample and chemistry and are potentially useful as time-stratigraphic markers.

Several lighter colored dacitic to rhyodacitic tuffs and flows, including one flow with abundant hornblende phenocrysts, were identified during a traverse of the southern boundary of section 35 . They have been included in Unit $C$ but are believed to have a distribution limited to the southern edge of the mapped area. 


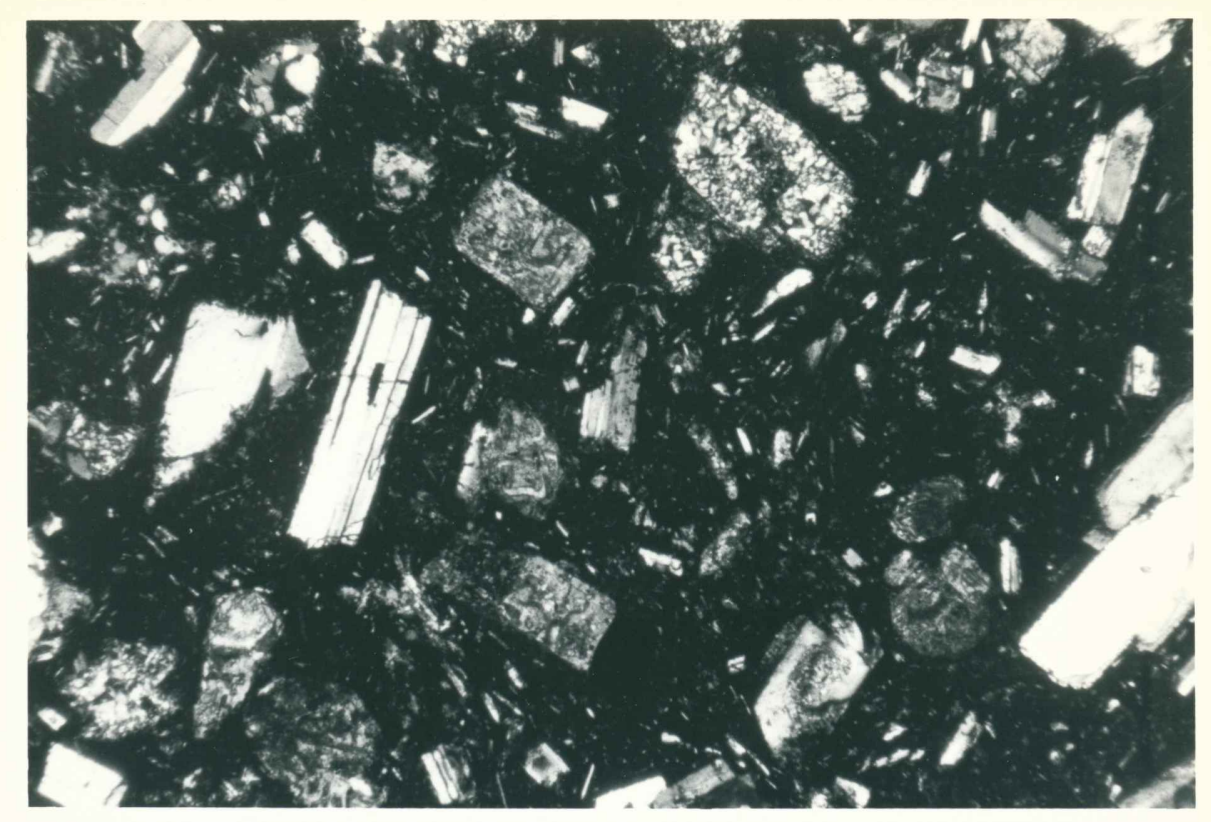

9 a

$9 b$
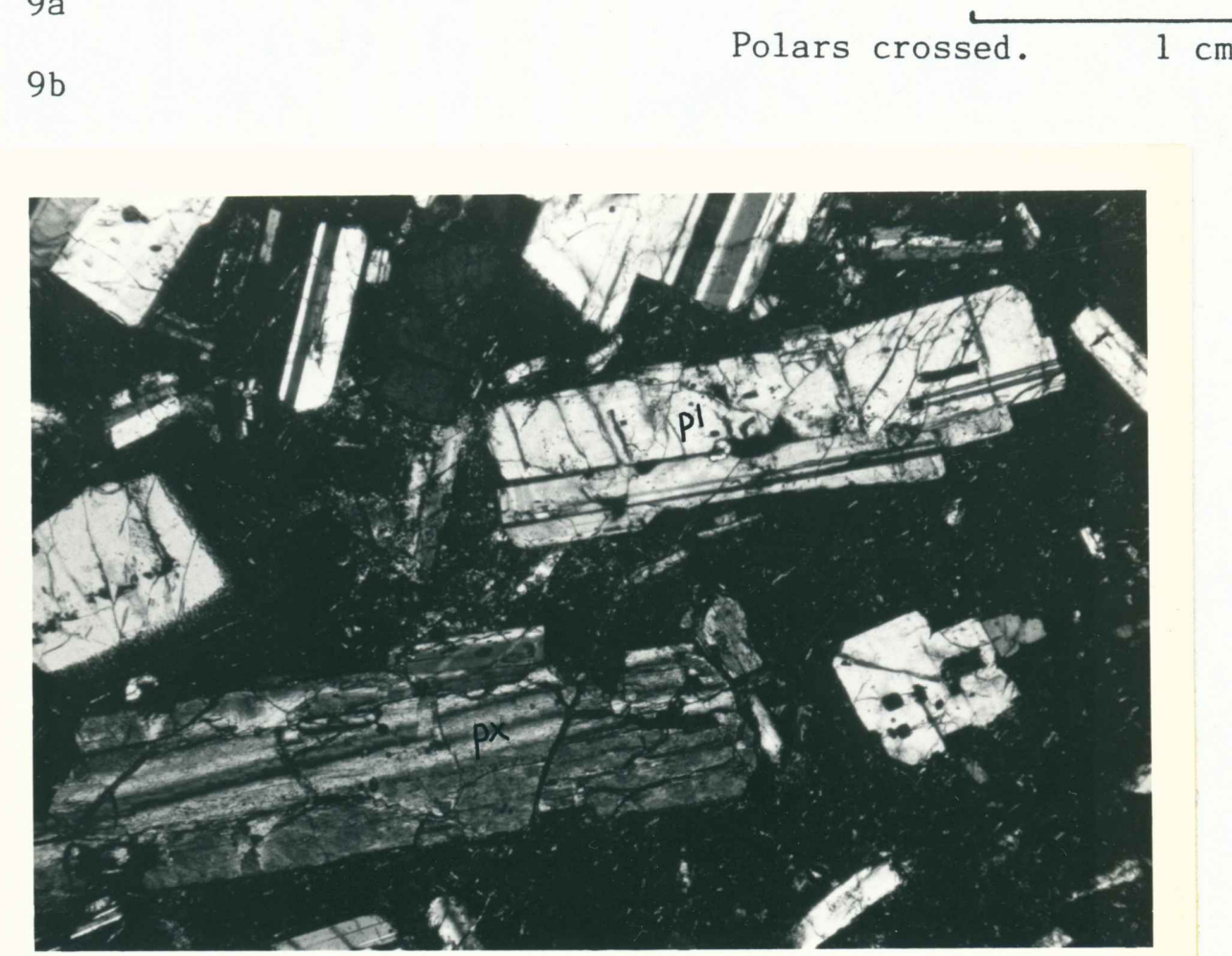

Figure 9. Photomicrographs of flows of Unit D. Rocks are dark brown to black andesites and basalts. Figure 9a is from the capping flow on Whetstone Mtn. (Wm-14). Figure $9 b$ is from south of Battle Ax Creek (B-35-1). Note similarity in size and shape of plagioclase ( $p 1)$ and pyroxene ( $p x)$ phenocrysts. 
Intrusions

Three major types of intrusions are distinguished and shown on Plates I and II. These types are distinguished on the basis of texture, mineralogy, and geometry of the unit. The diagnostic characteristics are summarized in Figure 10.

The equigranular diorite is the most abundant intrusive type in the study area and is best exposed at two localities along Battle Ax Creek; one upstream from the confluence of McCarver Creek and the other upstream from Henness Creek. Similar intrusions are also exposed on Whetstone Mountain north of Jawbone Flats and near the mouth of Third Creek. Equigranular diorite intrusions occur as northwest-trending

$\begin{array}{llll}\text { NAME } & \text { Equigranular diorite } & \text { Porphyritic diorite } & \text { Quartz-feldspar porphyry } \\ & & \\ \text { GROUNDMASS } & 5-10 \% & 60-70 \% & 60-70 \% \\ & & \text { Plagioclase } & \text { Plagioclase } \\ & & \text { laths and mafics } & \text { Quartz }\end{array}$

PHENOCRYSTS

\begin{tabular}{|c|c|c|c|}
\hline Feldspars & $\begin{array}{l}60-80 \% \\
\text { Andesine } \\
(\text { An40-50) }\end{array}$ & $\begin{array}{l}20-30 \% \\
\text { Plagioclase displays } \\
\text { strong compositional } \\
\text { zoning; calcic cores; } \\
\text { rims An } 35 \text {; some } \\
\text { glomerocrysts }\end{array}$ & $\begin{array}{l}10-30 \% \\
\text { Plagioclase } \\
\text { K-spar (?) }\end{array}$ \\
\hline $\begin{array}{l}\text { Mafic } \\
\text { Minerals }\end{array}$ & $\begin{array}{l}20-40 z \\
\text { Hypersthene } \\
\text { Augite } \\
\text { Biotite } \\
\text { Hornblende (?) }\end{array}$ & $\begin{array}{l}10-20 \% \\
\text { Pyroxene } \\
\text { Hornblende (?) }\end{array}$ & $\begin{array}{l}\text { Rare; } \\
\text { Hornblende }<17\end{array}$ \\
\hline Quartz & $\begin{array}{l}\text { Very Rare } \\
(<<1 \%)\end{array}$ & Rare $(<1 \%)$ & $5-15 \%$ \\
\hline COMMENTS & $\begin{array}{l}\text { NW-trending dikes (to } \\
20 \mathrm{~m} \text { ) commonly vesicular: } \\
\text { "salt and pepper" } \\
\text { appearance }\end{array}$ & $\begin{array}{l}\text { Narrow (to } 10 \mathrm{~m} \text { ) } \\
\text { NW-trending dikes; } \\
\text { narrow chilled margins }\end{array}$ & $\begin{array}{l}\text { Irregular shaped dikes, } \\
\text { and sills; leucocratic; } \\
\text { commonly with open-spaced, } \\
\text { "crackle breccias" and } \\
\text { well developed intrusive } \\
\text { breccias on margins; xeno- } \\
\text { liths common locally }\end{array}$ \\
\hline
\end{tabular}

Figure 10. Characteristics of the three types of intrusions in the east portion of the North Santiam mining area. 
dikes up to $20 \mathrm{~m}$ across. Contacts trend $\mathrm{N} .35^{\circ}-50^{\circ} \mathrm{W}$. and are steeply dipping to vertical. The equigranular texture of the feldspar and mafic phases (Figure 11) gives outcrops a distinctive "salt and pepper" appearance. Contacts are sharp with narrow chilled margins. Vesicles are common particularly near contacts (Figure 11b). Narrow, 0.5 to 3.0 $\mathrm{cm}$, white aplite veins, commonly intruded along N. $35^{\circ}-45^{\circ} \mathrm{W}$. fractures, cut these intrusions (Figure 11b) near Hennesse Creek. The more resistant aplite veins stand in relief on stream-polished surfaces.

Porphyritic diorite intrusions form 3 to $10 \mathrm{~m}$ thick dikes that display poorly developed horizontal jointing. The dikes commonly contain glomerocrysts of plagioclase and pyroxene. Plagioclase displays compositional zoning; cores of grains are more strongly altered to calcium-bearing secondary minerals than are the rims. These dikes are closely associated spatially with equigranular diorite dikes and are adjacent to, and parallel at two locations. Porphyritic diorite dikes trend $N .40^{\circ}-50^{\circ} \mathrm{W}$. They are best exposed adjacent to the portal of level 5 of the Ruth Mine, in a roadcut above the portal, in the adit, and in Battle Ax Creek downstream from the portal where the dike crosses from the north side of Battle Ax Creek (Figure 12) but cannot be traced along strike to the south side of the creek. Below the portal of the Ruth Mine in the stream bed of Battle Ax Creek the porphyritic diorite dike is in contact on its southwest margin with a quartz-feldspar porphyry sill. In and above the portal, the southwest margin is sheared along a N. $10^{\circ} \mathrm{W}$. trend. This diorite dike cannot be traced along strike to the north bank of Battle Ax Creek. 


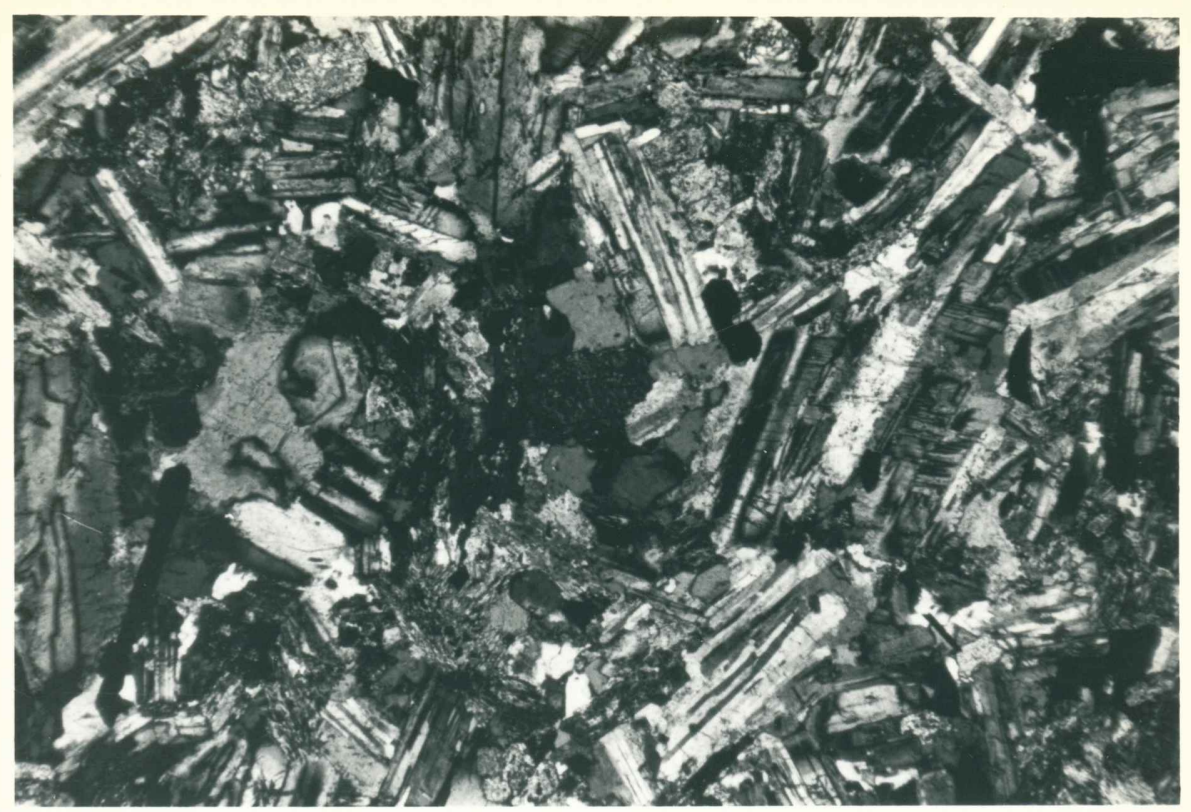

11a.

Polars crossed. $\quad 1 \mathrm{~cm}$

$11 \mathrm{~b}$.

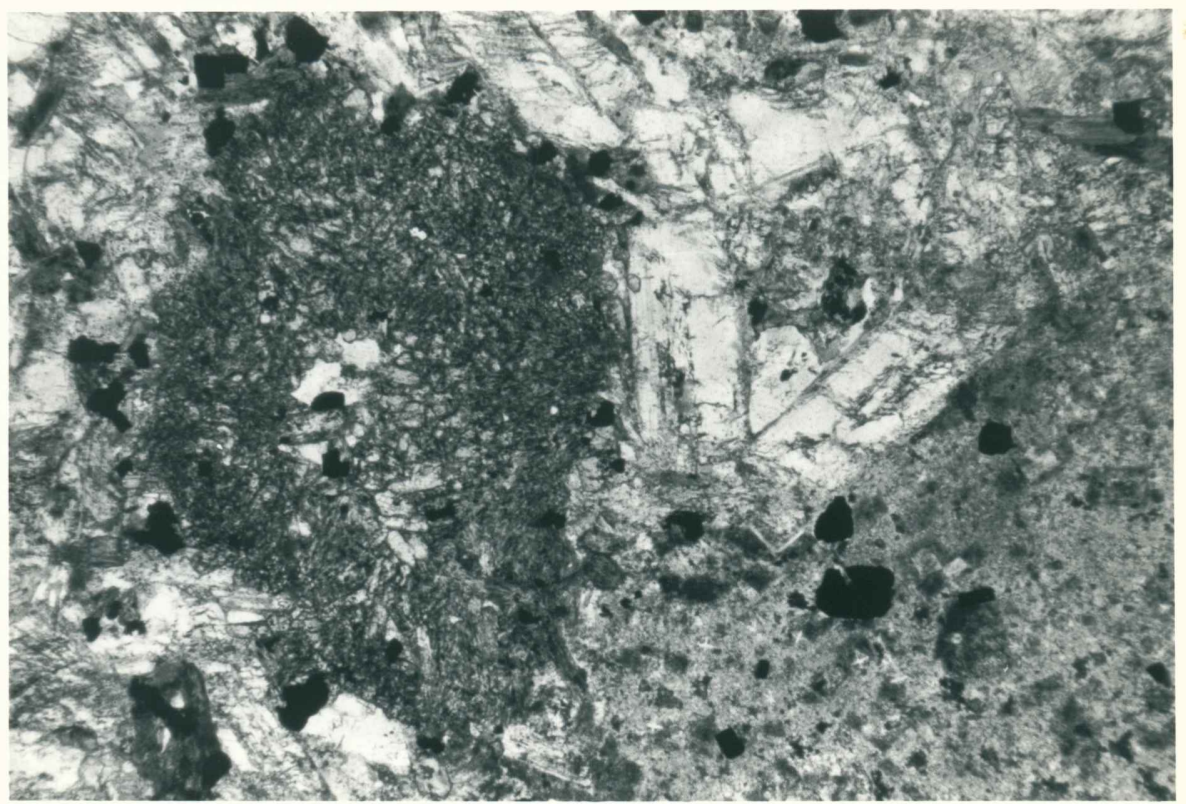

Figure 11. Photomicrographs of equigranular diorites. Minerals visible in 1la (BA-27-11c) include plagioclase, augite, hypersthene, and biotite. Similar grain sizes give the rock a "salt and pepper" appearance. In 11b (BA-27-23d), an aplite vein is shown in the lower right corner while the large dark area is a vesicle filled with epidote and quartz. 


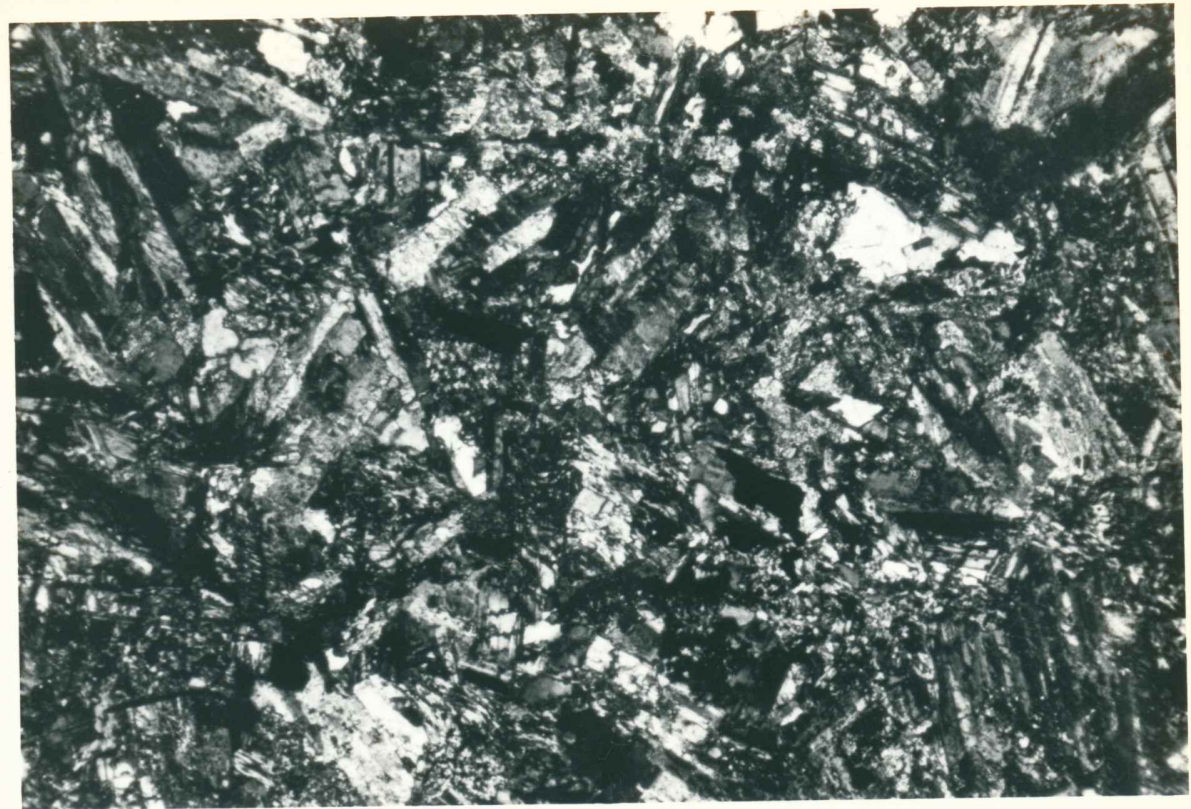

Figure 11c

Figure 11d

$1 \mathrm{~cm}$

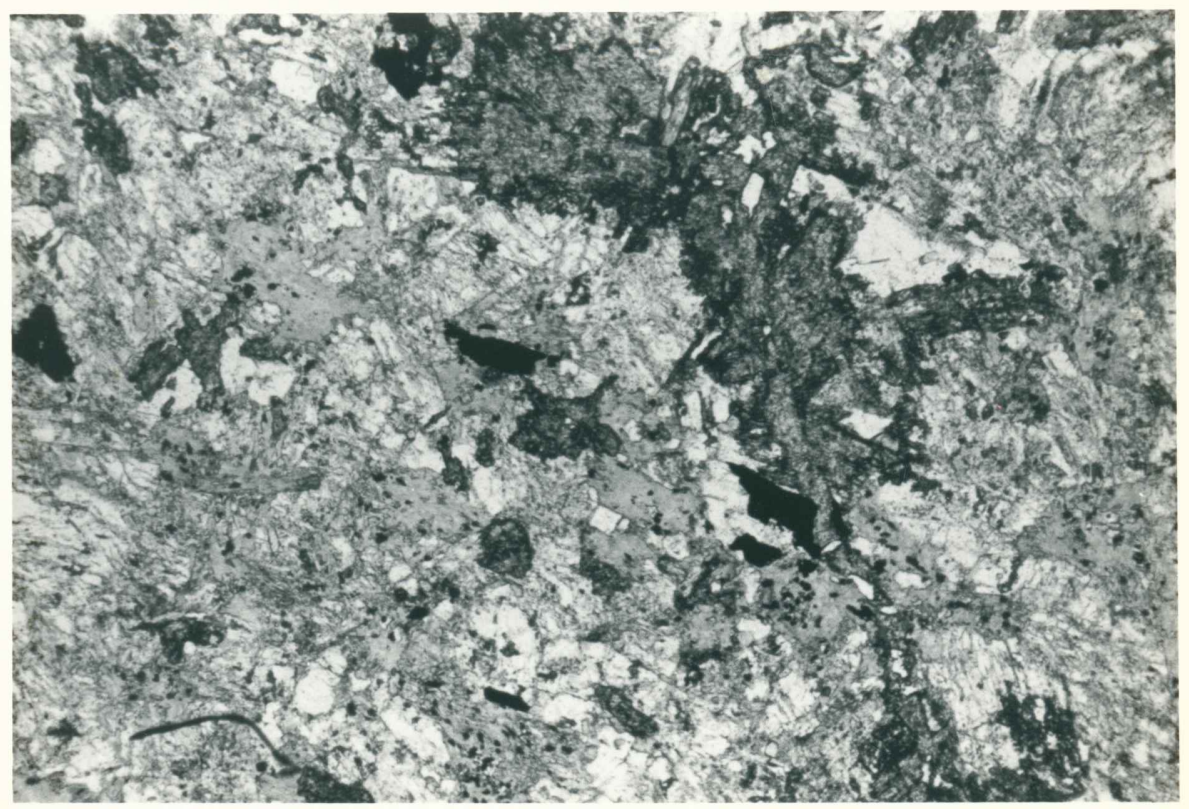

Figure 11 (continued). Figures 11c (polars crossed) and 11d (polars uncrossed) show the same view of an altered sample from an equigranular diorite dike (BA-27-11b). Mafic minerals are altered to chlorite, epidote, and opaque minerals; plagioclase to epidote. Epidote replacing groundmass forms a halo on fine fracture surfaces. 
The third intrusion type is a leucocratic quartz-feldspar porphyry. It is very light gray to white in color and has 5 to $10 \%$ quartz phenocrysts, 0.5 to $2 \mathrm{~mm}$ in diameter and euhedral to nearly round in shape as shown in Figure 13. Each quartz phenocryst contains a single, centrally located zircon. Plagioclase phenocrysts are also present in all samples. Hornblende crystals to $2 \mathrm{~mm}$ in length are rare; no other mafic phases are present. The geometry of the intrusions is very irregular. The contacts are steeply dipping to nearly horizontal at different outcrops and within the same outcrop. Exposures near McCarver and Henness Creeks below $800 \mathrm{~m}(2,600 \mathrm{ft})$ elevation are probably continuous with those in Battle Ax Creek. It is well exposed within the Ruth Mine. Below the portal of the Ruth Mine in Battle Ax Creek a sill appears to intrude and dome the polymictic breccia. On Whetstone Mountain the intrusion becomes increasingly well-jointed with increased elevation. At an elevation of $950 \mathrm{~m}$ (3100 ft), the intrusion forms a pinnacle 30-35 m high displaying well-developed, steeply dipping columnar joints.

Four additional andesite (?) dikes, each 1 to $4 \mathrm{~m}$ across, are shown on Plates I, II and III. They are finer grained than the porphyritic diorite which they otherwise resemble. One, located near the center of section 28 , trends N. $40^{\circ} \mathrm{W}$. and contains about $5 \%$ partially resorbed quartz phenocrysts. Another, located in Battle Ax Creek downstream from the mouth of Third Creek, strikes N. $60^{\circ}$ E. and dips $65^{\circ} \mathrm{NW}$. Contacts against the polymictic breccia it intrudes are sharp. It is located in an area with a strong N. $60^{\circ}$ E. fracture set not found as a dominant fracture orientation elsewhere in the study 


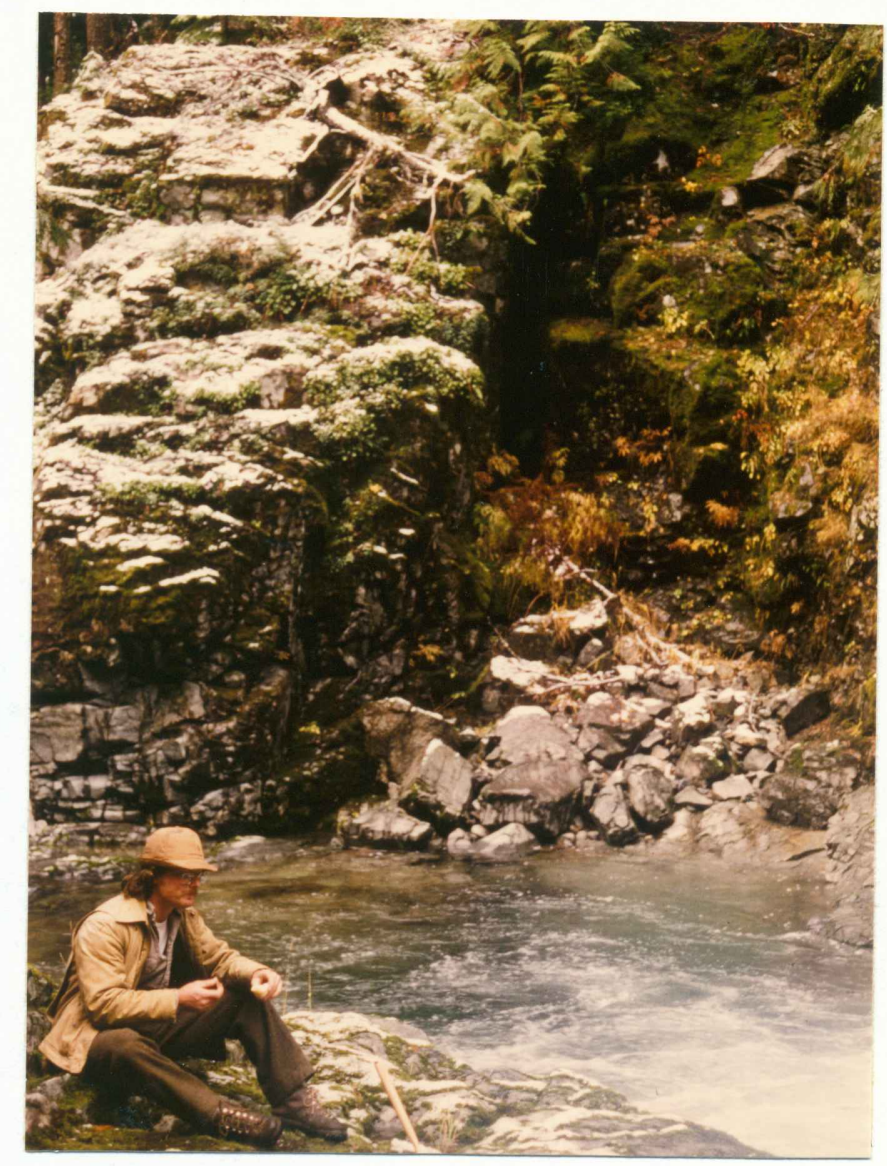

Figure 12. Photograph of porphyritic diorite dike on the north bank of Battle Ax Creek downstream of the Ruth Mine.

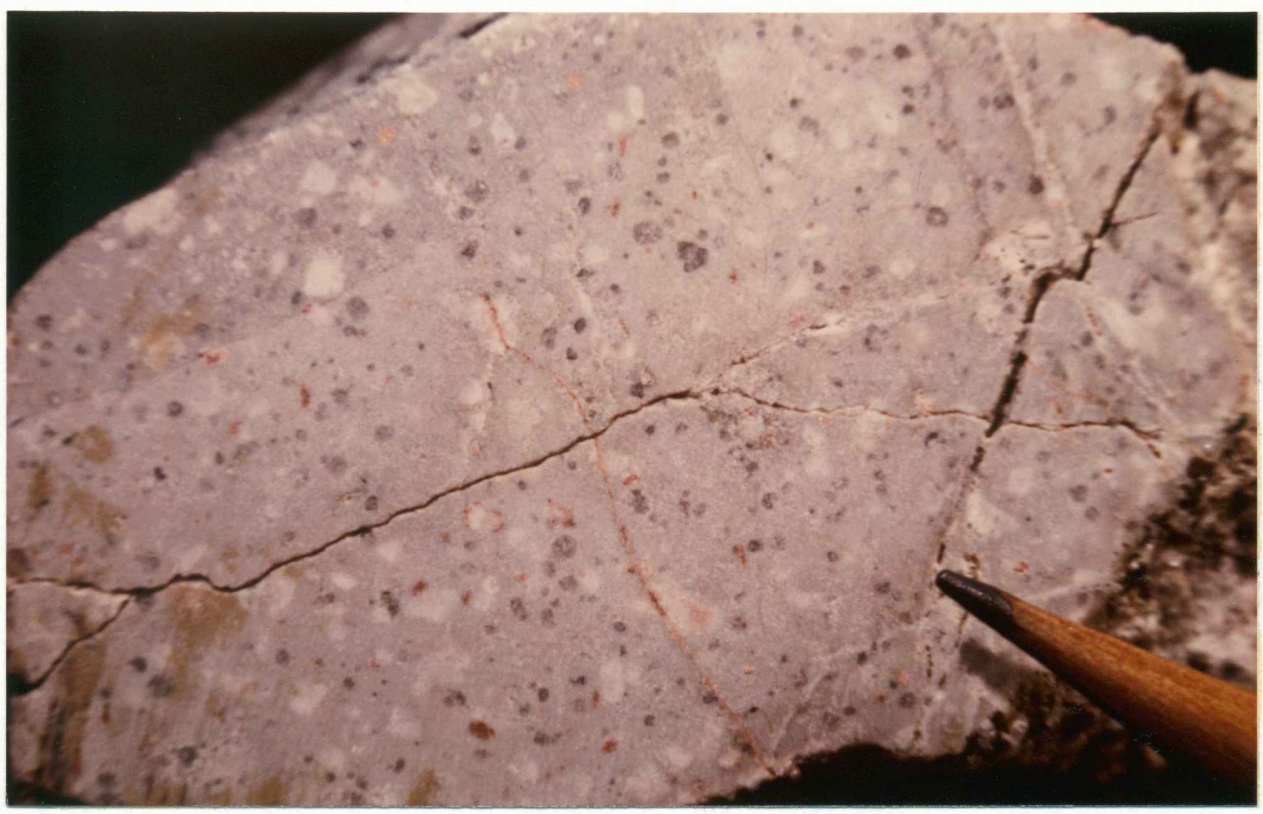

Figure 13. Photograph of handsample from a quartz-feldspar porphyry intrusion. The open-space "crackle" breccia is cemented with quartz, sphalerite, and galena. 
area. Two exposures within the adit of the Ruth Mine (Plate III) show strong alteration halos but no base metal mineralization.

\section{Structure}

All units within the area are nearly horizontal to gently dipping to the southeast as illustrated on the cross-section in Figure 14. Measured dips range from $5^{\circ}$ to $20^{\circ}$. Correlation of the first occurrence of an andesite flow of Unit B on Whetstone Mountain and on Henness Creek results in a calculated dip of $11^{\circ}$ to the southeast. This calculated dip is similar to the $13^{\circ}$ dip measured on flattened pumice of a tuff of unit A (sample WM-1) on Battle Ax Creek in section 27 and is believed to approximate the dip of the contact between Units $A$ and B. The lower slope of Whetstone Mountain is a virtual dip slope. Dips decrease higher in the section and to the south.

Units $B$ and $C$ thin to the north as the result primarily of a decrease in the number of flows and tuffs and secondarily as a result of a thinning of individual deposits. The base of Unit $A$ is not exposed and the top of Unit $D$ has been removed by erosion.

Three high angle fracture and fault sets are identified in the study area, each of which serves to control topography. The most prominent set is oriented $\mathrm{N} \cdot 40^{\circ}-50^{\circ} \mathrm{W}$. and controls the trends of Opal, McCarver, Third Creeks, the northeast fork of Henness Creek and numerous smaller drainages. The second, oriented N. $5^{\circ}-20^{\circ} \mathrm{W}$, controls the main branch of Henness Creek and several unnamed drainages on Whetstone Mountain. The third is oriented from N. $80^{\circ}$ E. to eastwest and appears to control much of the trend of Battle Ax Creek. The 


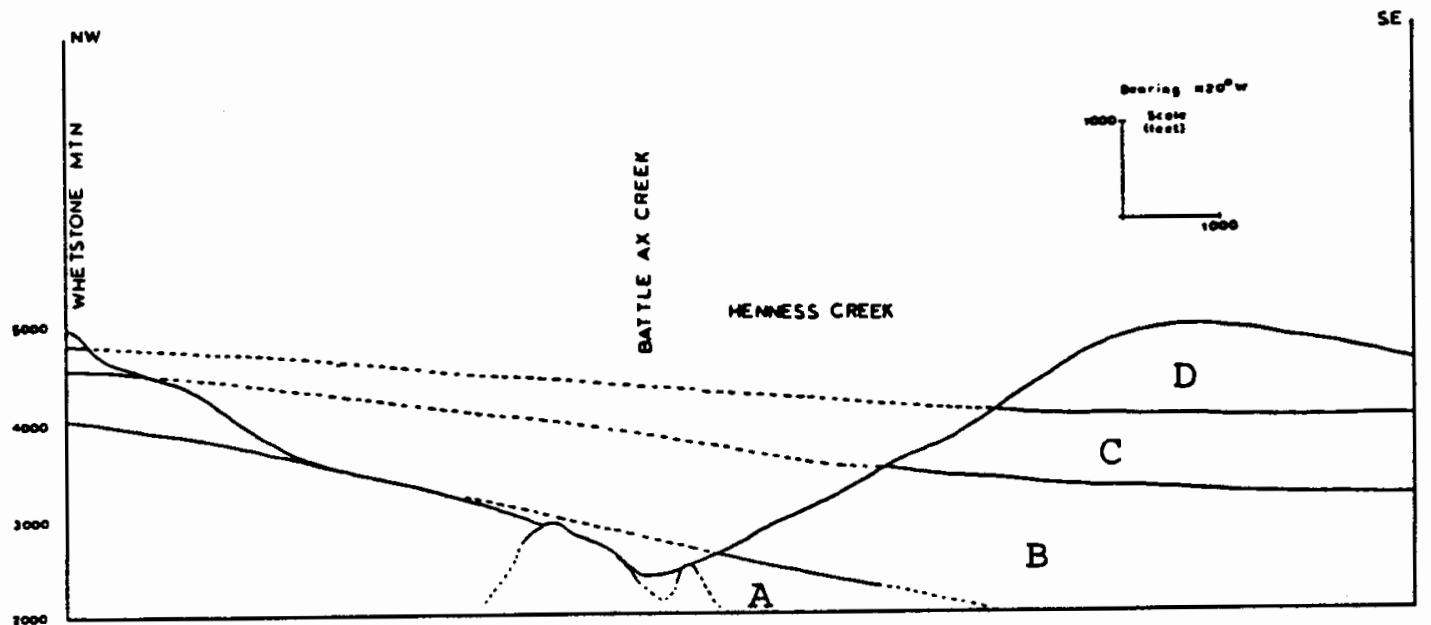

Figure 14. Geologic cross-section in the vicinity of the Ruth Mine.

N. $40^{\circ}-50^{\circ} \mathrm{W}$. fracture set is subordinate to other orientations in the flows of Unit D.

Displacements across faults are difficult to determine due to poor exposures, the similarities among lithologic units, and the fact that along Battle Ax Creek, where exposures are the most extensive, major faults are bounded on one or both sides by intrusions. Slickensides on $\mathrm{N} .40^{\circ}-50^{\circ} \mathrm{W}$. and east-west faults are all nearly horizontal. Where east-west faults and $\mathrm{N} .45^{\circ}-50^{\circ}$ W. faults intersect within the Ruth Mine, the east-west faults either offset or bend into alignment with the northwest faults with no apparent offset. The N. $5^{\circ}$ to $20^{\circ} \mathrm{W}$. fractures cross both sets without apparent displacement. The main fork of Henness Creek shown in Figure 15, which trends N. $10^{\circ}$ W., is exceedingly straight suggesting fault control, however, units are not displaced across this creek. 


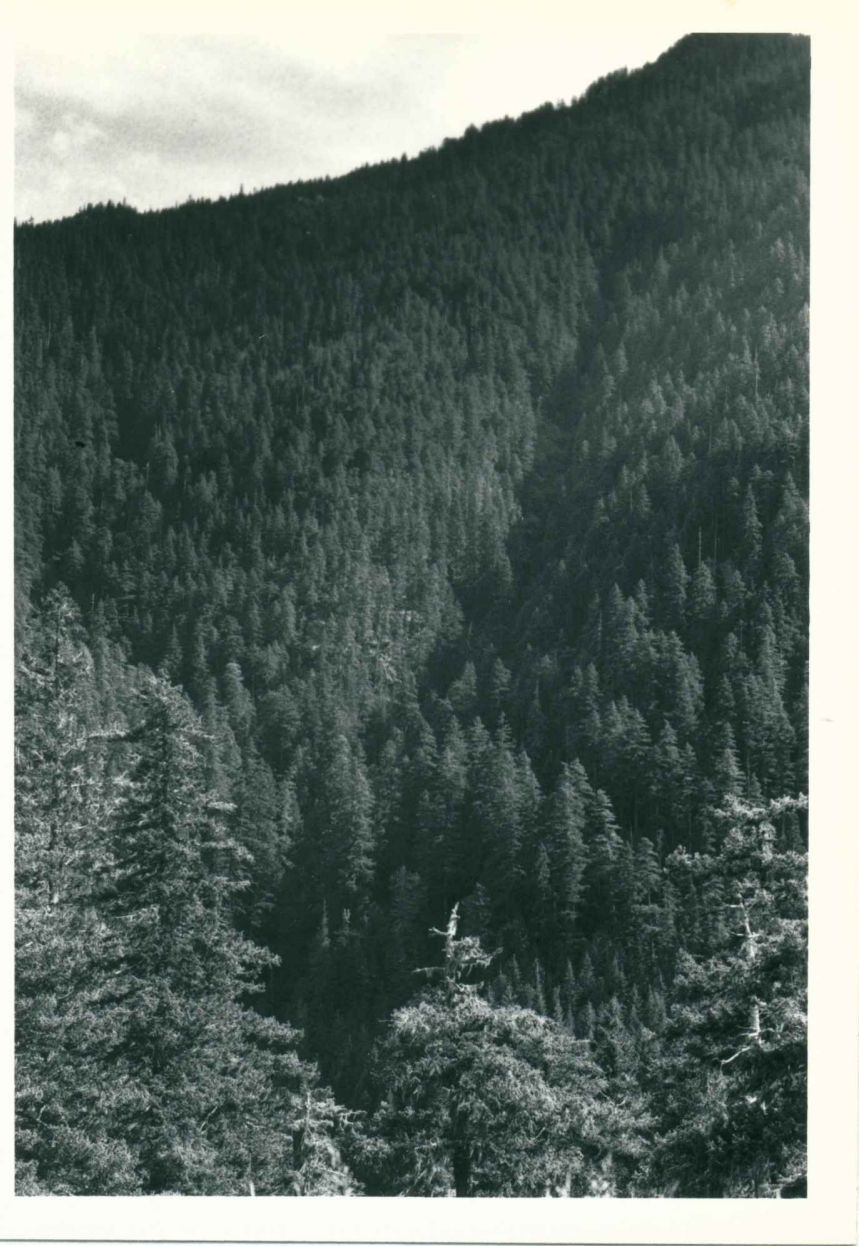

Figure 15. Photograph of main fork of Henness Creek taken from the top of the quartz-feldspar porphyry intrusion on Whetstone Mountain looking southeast along the line of cross-section in Figure 14. 
CHAPTER IV

ALTERATION AND MINERALIZATION

Alteration types and general distribution

The entire study area is located within the propylitic alteration zone as defined by 01son (1978). Alteration is not, however, uniform and areas of quartz-sericite and argillic alteration are important in evaluating the hydrothermal and mineralization history of the area. In general, alteration is most intense at lower elevations in the western part of the study area and decreases to the south and east. Alteration also decreases with increase in elevation throughout the area. Descriptions of the general nature of the alteration types and their general distribution are presented followed by description of two alteration zones examined in detail.

Propylitic alteration consisting of the replacement of primary mafic minerals by one or more of the minerals chlorite, calcite, and epidote, and plagioclase by epidote or calcite, is widespread but becomes more intense in the vicinity of northwest-trending structures and intrusions. In the least altered rocks, hornblende and fibrous amphiboles such as uralite, which formed after pyroxenes, are altered to chlorite. Rocks exhibiting this degree of alteration may contain calcite or chlorite-calcite veinlets such as those which cross-cut flows of Unit D on Whetstone Mountain (Figure 16). 


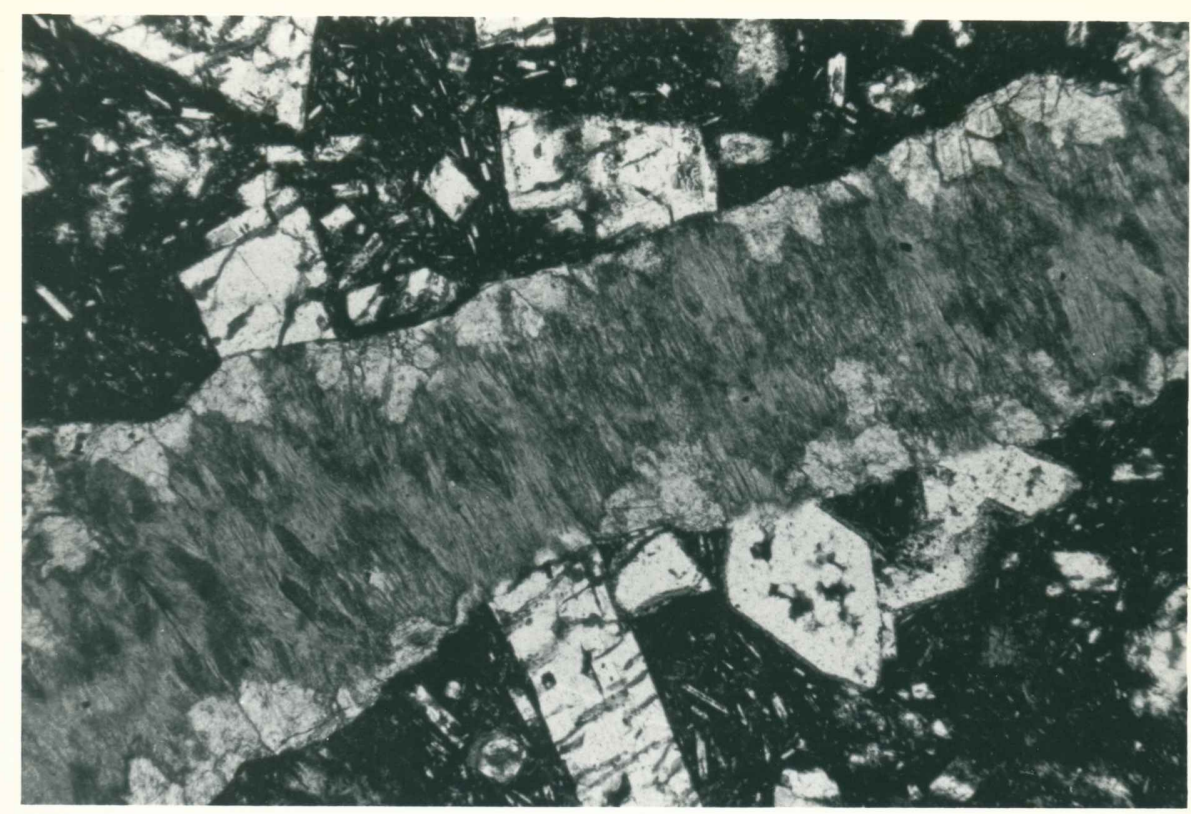

Figure 16. Calcite-chlorite veinlet in flow of Unit D. Calcite grown along the walls and fibrous chlorite grown perpendicular to the walls completely fill this vein. Silicification of vesicles in this sample is not shown in the photomicrograph. (Sample WM-14)

Epidote appears as a replacement of first mafic phenocrysts, and then mafic and plagioclase phenocrysts, with increasing depth in the stratigraphic section and in the vicinity of intrusions. Where the development of replacement epidote is extensive, epidote and quartz is precipitated in veinlets and as vesicle fillings. Larger veinlets are accompanied by halos, extending up to $3 \mathrm{~cm}$ into the walls of veins and vesicles, in which epidote replaces groundmass minerals. This is well illustrated by the alteration of the equigranular diorite dikes near the confluence of McCarver and Battle Ax Creeks. Quartz in these epidote-quartz veinlets contains abundant fluid inclusions.

Phyllic or quartz-sericite alteration is defined as the replacement of groundmass and phenocrysts by fine grained high 
birefringent clays or micas and fine grained quartz. Where these fine grained minerals have been analyzed by $x$-ray diffraction, they $y$ ield patterns of $10 \mathrm{~A}$ sheet silicates which may be either illites or fine grained muscovite. Since these minerals are indistinguishable by the methods of analysis used, they are referred to by the imprecise petrographic term sericite. Phyllic alteration is recognized in the field by a loss of primary textures and a progressive bleaching of the samples in halos around veins, faults, and larger fractures. Bleaching is caused by the destruction of primary mafic phases and secondary phases such as chlorite. Iron removed in the alteration of these phases is retained in disseminated pyrite.

Phyllic alteration is best developed in the tuffs near faults and within the open breccia of the quartz-feldspar porphyry intrusions. Argillic alteration is defined as the moderate to total replacement of the rock by kaolinite. Zones of argillic alteration are best developed along N. $30^{\circ}-40^{\circ} \mathrm{W}$. and N. $80^{\circ}$ E. faults. The extent of argillic alteration is generally limited to the breccia zones along the faults and hence occurs in the hanging wall of mineralized veins. Clay zones range in thickness from a few centimeters up to 3-4 neters at places in the Ruth Mine. Clasts of partially altered host rock breccia fragments are found within the clay veins. X-ray analysis of clay zones in the Ruth Mine confirms the presence of kaolinite and also reveals the presence of $10 \mathrm{~A}$ clays and chlorite. Samples containing chlorite display a greenish color with an intensity related to the concentration of the chlorite. Swelling clays are absent from all analyzed samples of vein clay. 
Precipitated stilbite and laumontite have been identified as vein materials at lower elevations in the McCarver, Hennesse, and Third Creek drainages. Near the confluence of McCarver and Battle Ax Creeks, a multiple zeolite vein with fibrous laumontite near the vein walls and 3-5 $\mathrm{mm}$ euhedral stilbite in the core of the veins cuts the equigranular diorite along a N. $45^{\circ} \mathrm{W}$. fracture. Within the Ruth Mine, minor veining of laumontite and stilbite is found (Plate III). This veining has not been observed to be directly associated with base metal veins and, in those cases where they intersect, the zeolites are localized on trends of approximately N. $80^{\circ} \mathrm{E}$. and cross-cut the northwest-trending mineralized veins.

\section{Alteration of tuffs of Unit $\underline{A}$}

Alteration of the tuff which immediately overlies the polymictic breccia in unit $A$ has been studied in detail. Propylitically altered samples of this tuff collected near the Ruth Mine (section 27) and in Opal Creek (section 33) show primary textures of a lapilli-tuff. With increasing phyllic alteration, the rock loses its primary fragmental textures. The relatively uniform distribution of feldspar crystals within fragments and groundmass results in an appearance easily mistaken for a porphyritic flow. However, the tuff may be identified by the following features: 1) relative stratigraphic position above the polymictic breccia, 2) the occurrence of the parallel steeply dipping zones within its base, 3) ghosts of fragmental textures on wet, stream-polished surfaces, and 4) the alignment of broken phenocrysts along relict clast boundaries in thin section. 
Clast boundaries are distinct in the photomicrograph of a sample of relatively unaltered tuff (Figure 17a). Samples identified as BA-28-2 (Figures 17 and 18) were collected from a single outcrop along Battle Ax Creek 100 to 150 m northwest of Jawbone Flats (Plate II). All samples are intensely altered. Lighter colored or "bleached" zones occur throughout the outcrop as halos along the larger fractures. The darker color in sample BA-28-2 $\mathrm{j}$ is related to chlorite or chloritic clays within the matrix and the groundmass of contained lithic fragments. As the samples become increasingly "bleached", the percentage of chlorite and calcite decreases and the percentage of quartz, sericite, and pyrite within the matrix and groundmass increases. Kaolinite may be present in some of the most highly bleached samples. Plagioclase is altered to epidote, calcite, and sericite. Plagioclase is present in all sections examined, even those which are most strongly bleached. No original mafic minerals remain. Lath-shaped phenocrysts, believed to have been pyroxenes have been completely altered to chlorite. Epidote, calcite, chlorite, and sericite replace other phenocrysts which may have been mafic minerals. Pyrite, unidentified opaque minerals, sphene, and weakly pleochroic apatite are present within or adjacent to many relict mafic phenocrysts but are generally absent from plagioclase phenocrysts. In the most highly altered samples the presence of these minerals is often the only clue to the identity of the phenocryst. 


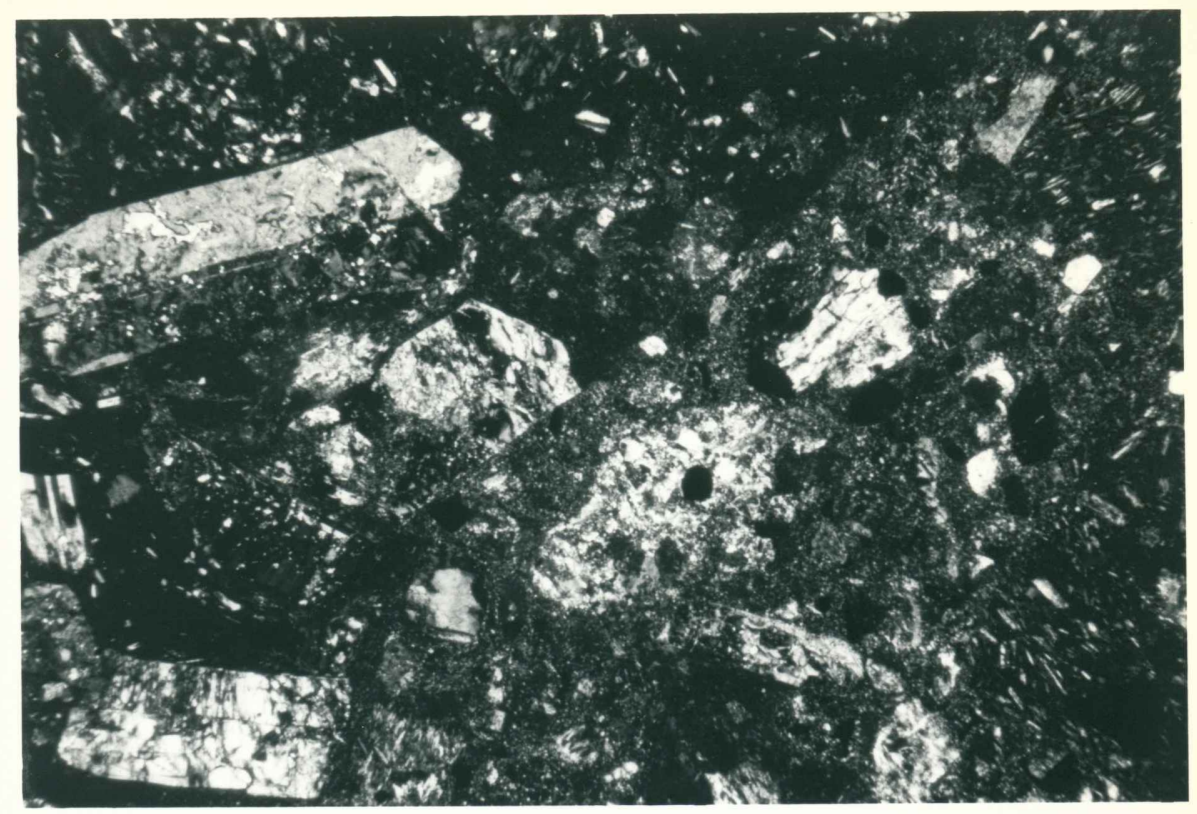

17 .

$17 \mathrm{~b}$.

Polars crossed. $1 \mathrm{~cm}$

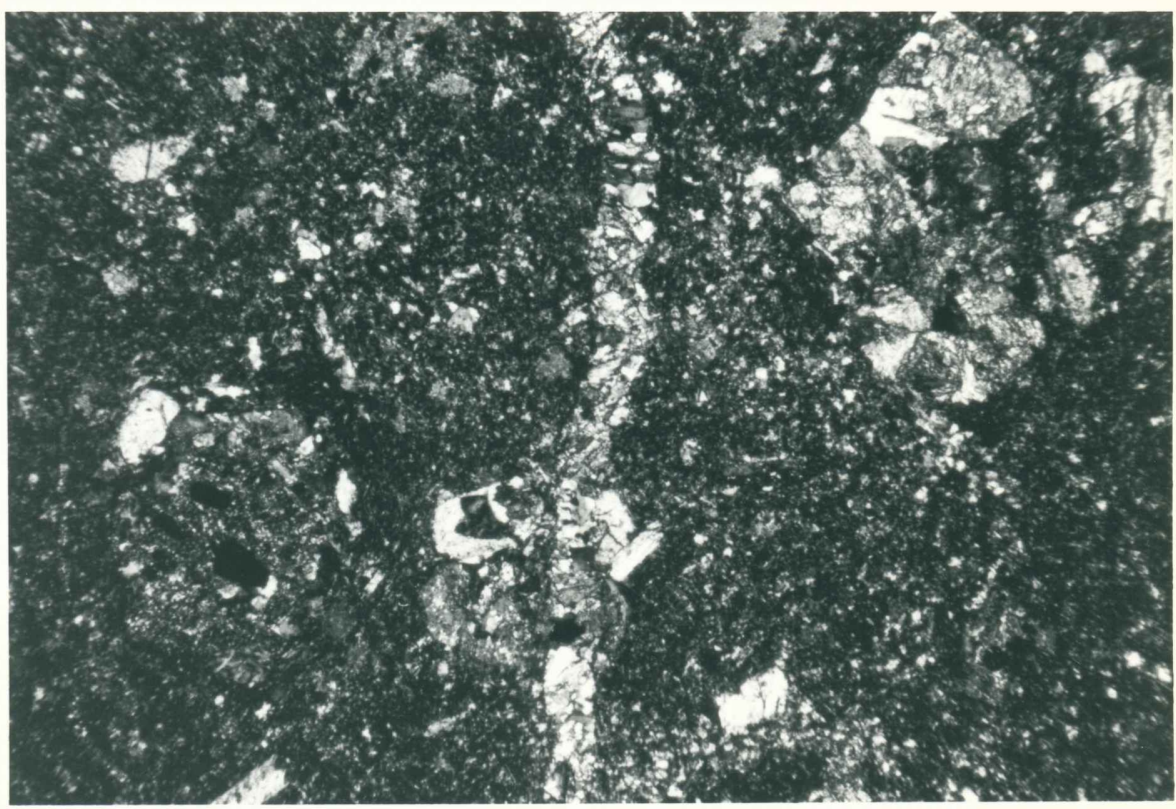

Figure 17. Photomicrographs of altered tuffs from Unit A. Figure 17 a illustrates a relatively fresh sample (RD-27-10). A clast boundary crosses diagonally. Note the broken phenocrysts along this boundary. Note the fine epidote veinlet in the propylitically altered tuff in $17 \mathrm{~b}$ (BA-28-2j). 


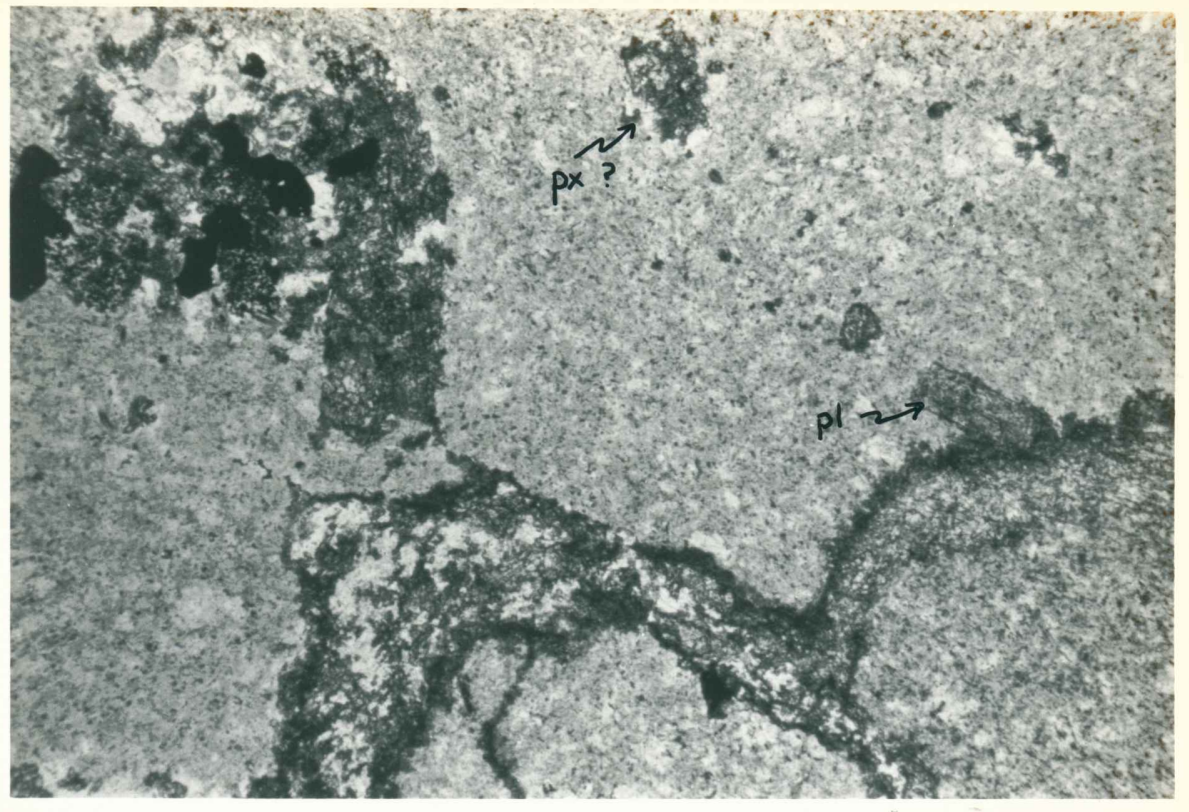

17c.

$17 d$.

$$
\text { Polars uncrossed. } 1 \mathrm{~cm}
$$

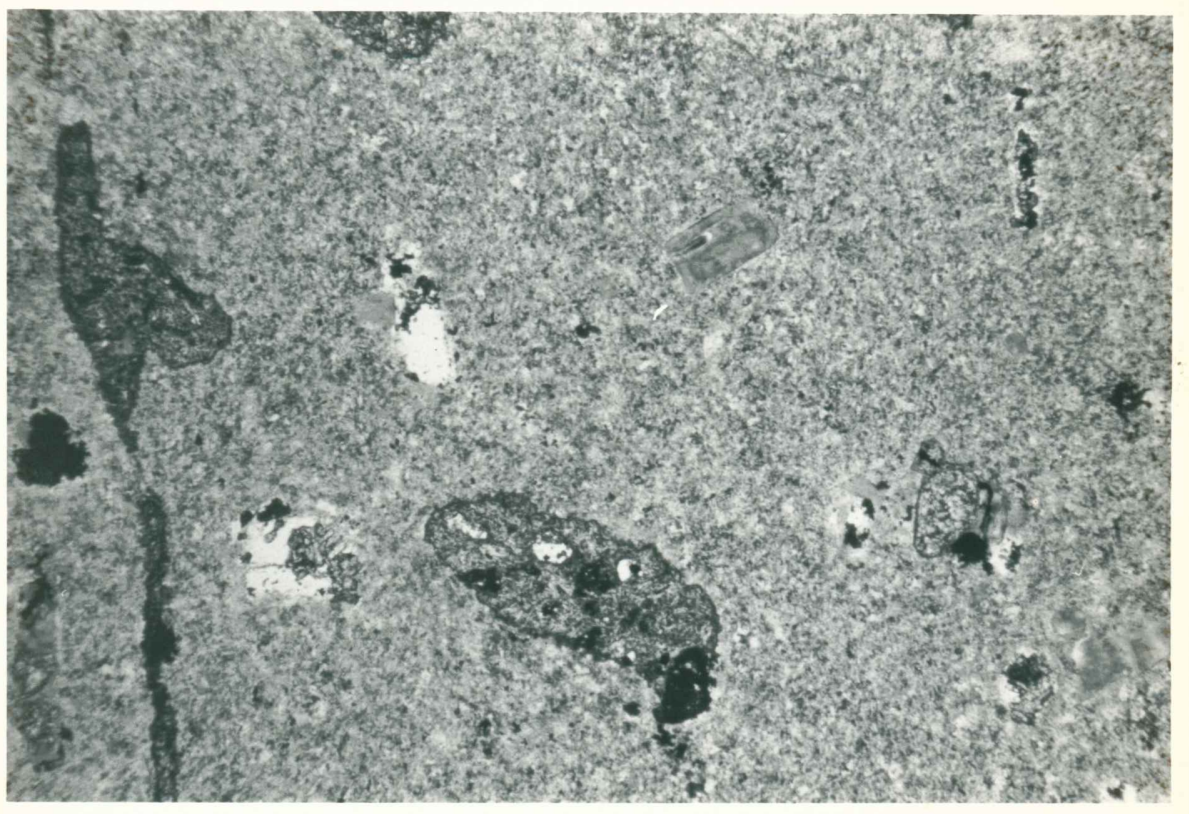

Figure 17 (continued). In 17c, quartz-epidote veining is shown in a thoroughly altered tuff (BA-28-2g). Pyroxene (?) phenocryst in upper center is altered to epidote, chlorite, quartz, kaolinite, and pyrite. Plagioclase adjacent to vein is altered to epidote. The intense bleaching of phy1lic alteration zones is shown in $17 \mathrm{~d}$ from sample BA-28-2d. 


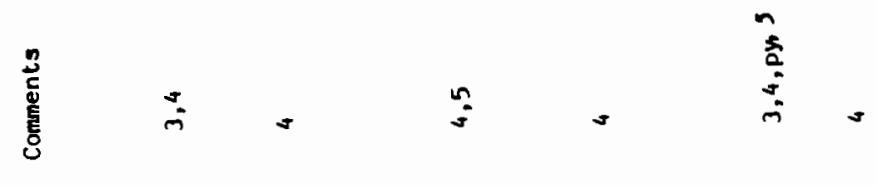

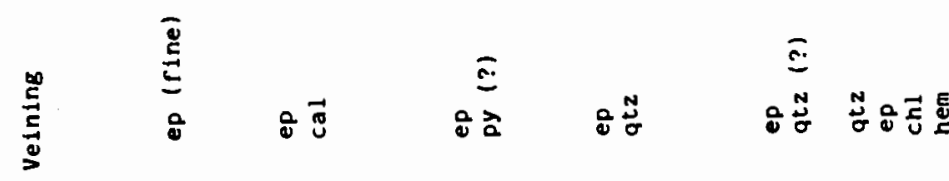

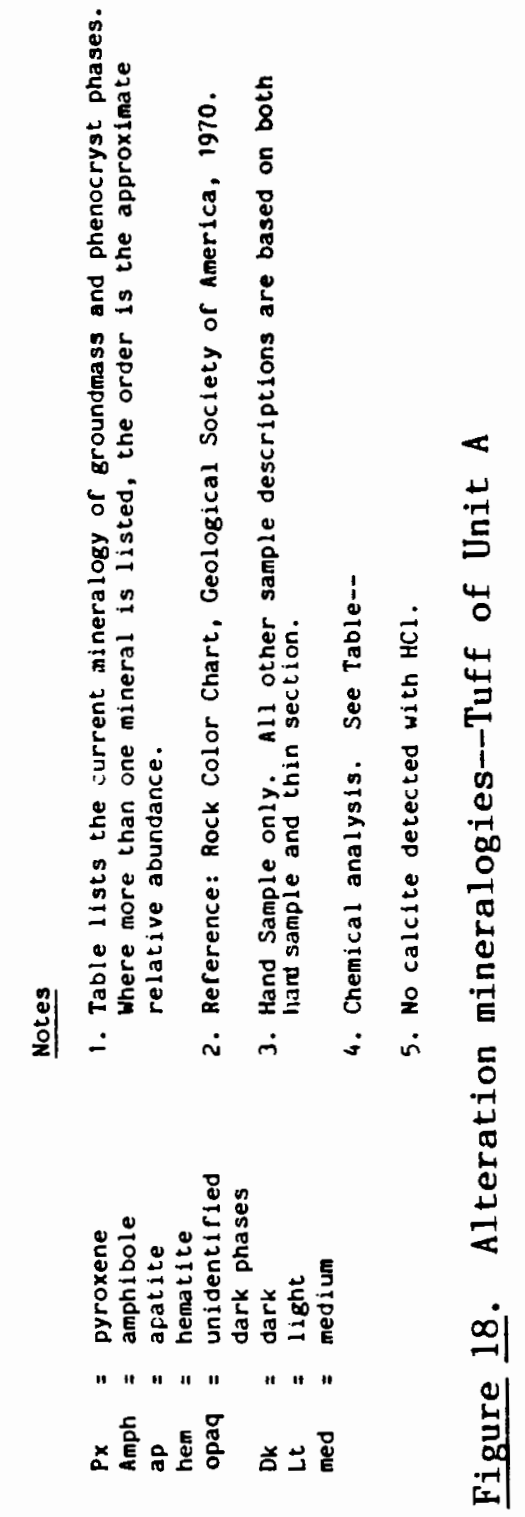

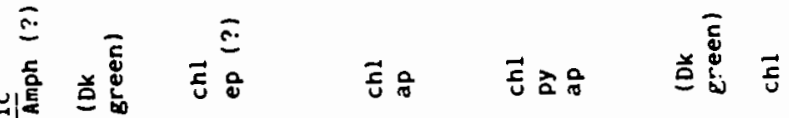

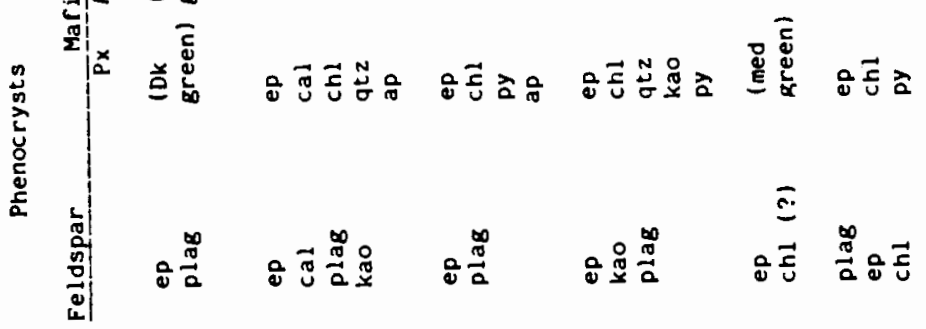

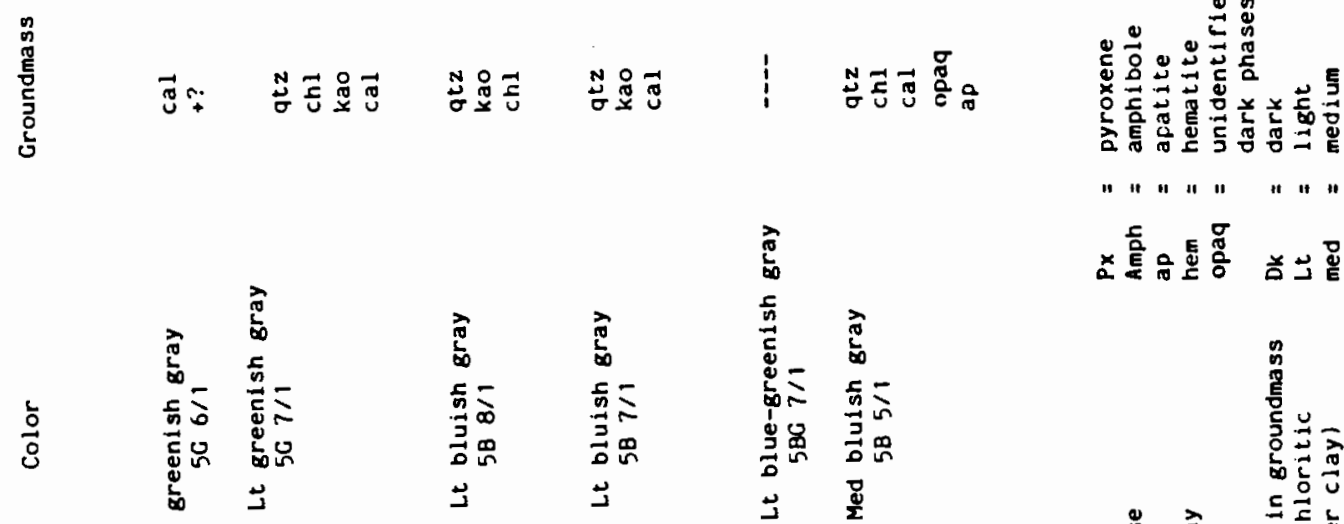

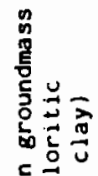

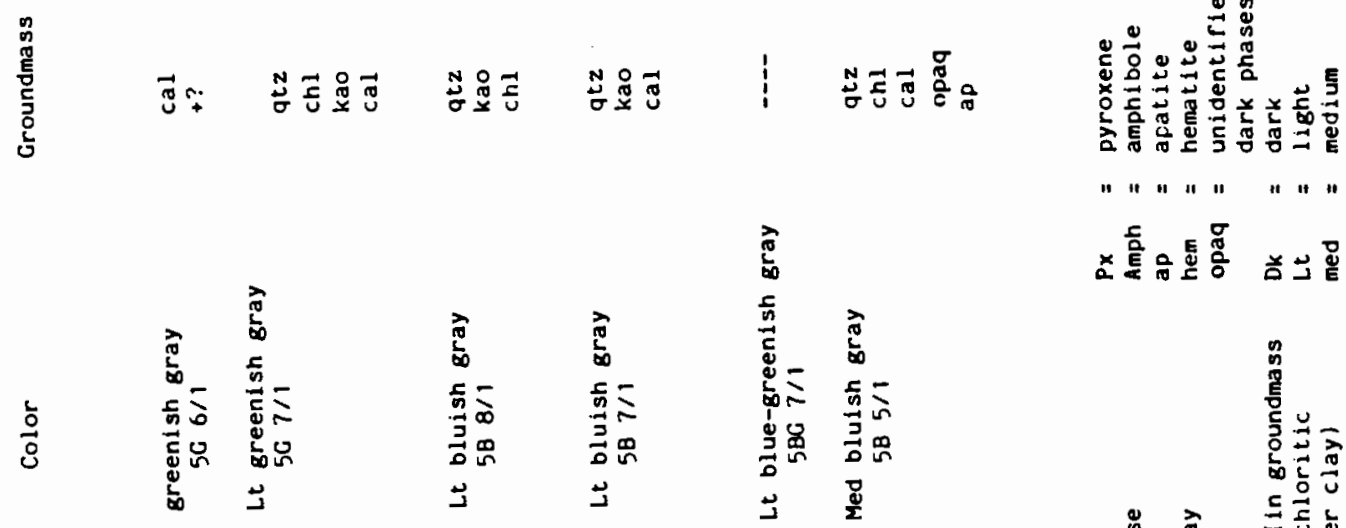

剂

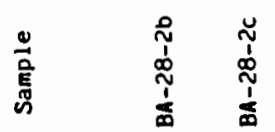

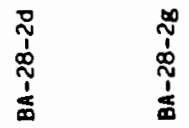

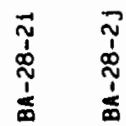

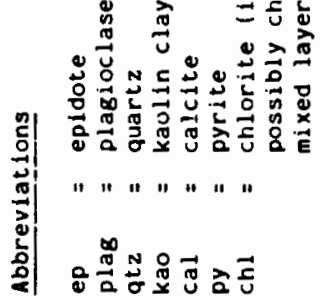


Alteration of quartz-feldspar porphyry

Exposures of the quartz-feldspar porphyry exhibit moderate to intense quartz-sericite alteration. The groundmass consists of very fine grained quartz which has grown in optical continuity with quartz phenocrysts to a distance of up to $0.1 \mathrm{~mm}$ from the original grain boundaries. Original grain boundaries of the quartz phenocrysts are preserved by sericite rims and the quartz of the overgrowth is intergrown with sericite (Figure 19a). Feldspars are partially to completely sericitized (Figure 19b). Rare mafic phenocrysts which appear to have been hornblendes are chloritized in one sample from Whetstone Mountain or are silicified with the location of the primary grain boundaries indicated by the distribution of fine grained opaque minerals.

Description of base-metal veins

Quartz veins, with or without calcite, serve as hosts for sulfide mineralization. A general paragenetic sequence as illustrated by the mineralized veins in the Morning Star Mine is shown in the photograph of an ore sample from the mine (Figure 20) and summarized in Figure 21. The host andesite tuff of unit A was propylitically altered and then brecciated. Growth of early quartz crystals in open space resulted in euhedral quartz attached to the breccia fragments and vein walls. Zonation in the growth of the quartz crystals began with a core of relatively inclusion-free quartz followed by one or more zones of abundant fine (typically $0.005 \mathrm{~mm}$ ) fluid inclusions parallel to growth surfaces. Zones of included fine grained solid phases are also common. 


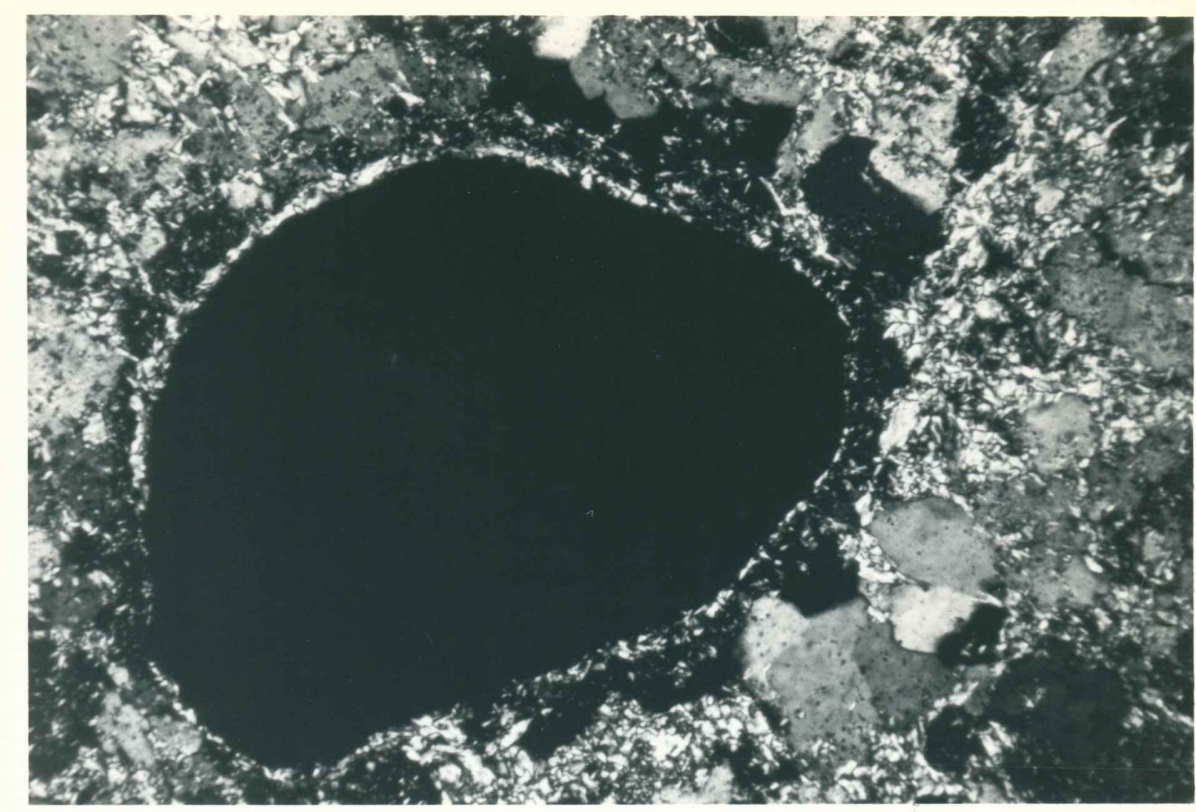

$19 \mathrm{a}$

$19 b$
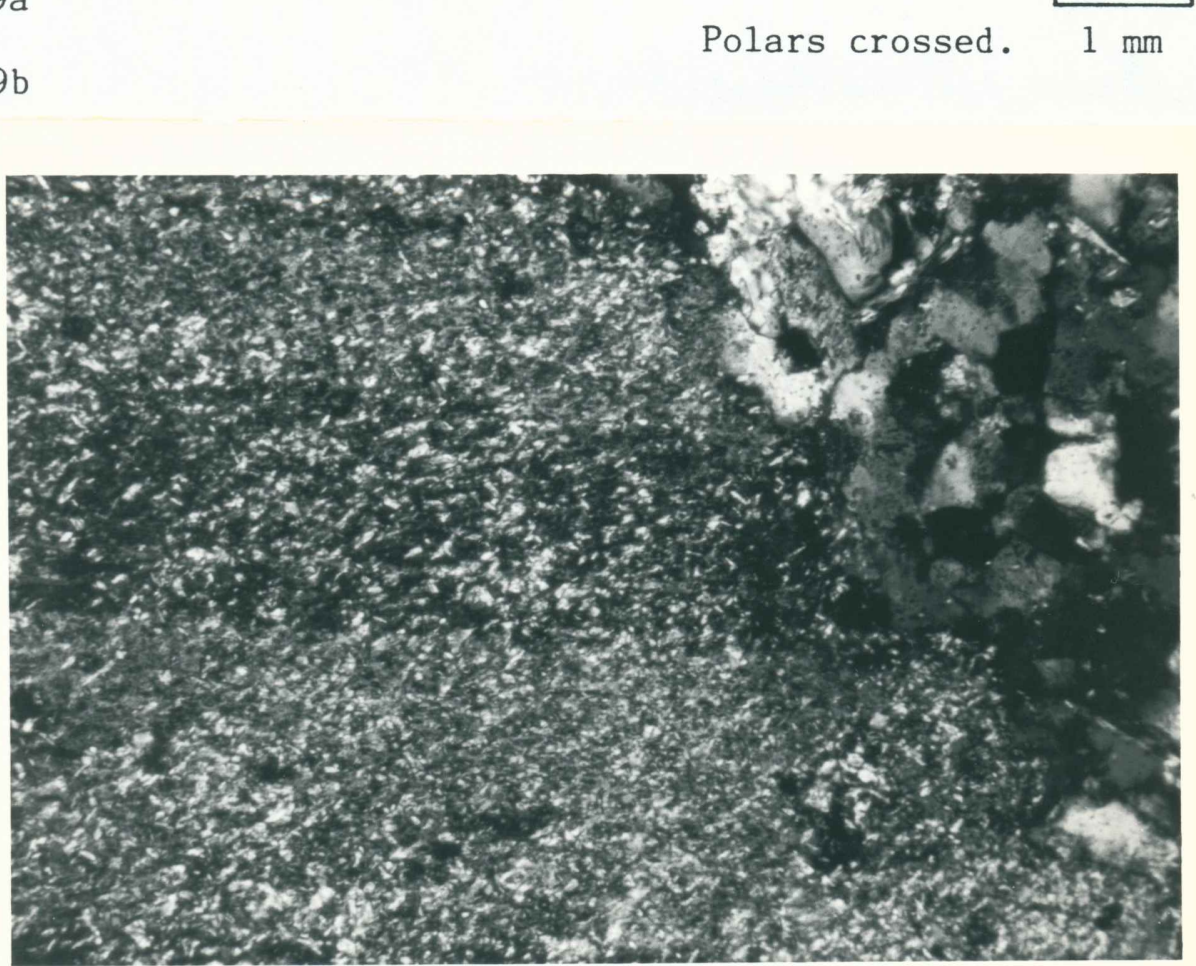

Figure 19. Photomicrographs of quartz-feldspar porphyry.

The boundary of a quartz phenocryst (at extinction in 19a) is preserved by a concentration of sericite in this phyllically altered sample (R5-1250a). Replacement quartz in groundmass is grown in optical continuity with phenocryst. Sericite in a twinned plagioclase phenocryst is visible in 19b (R-16). 


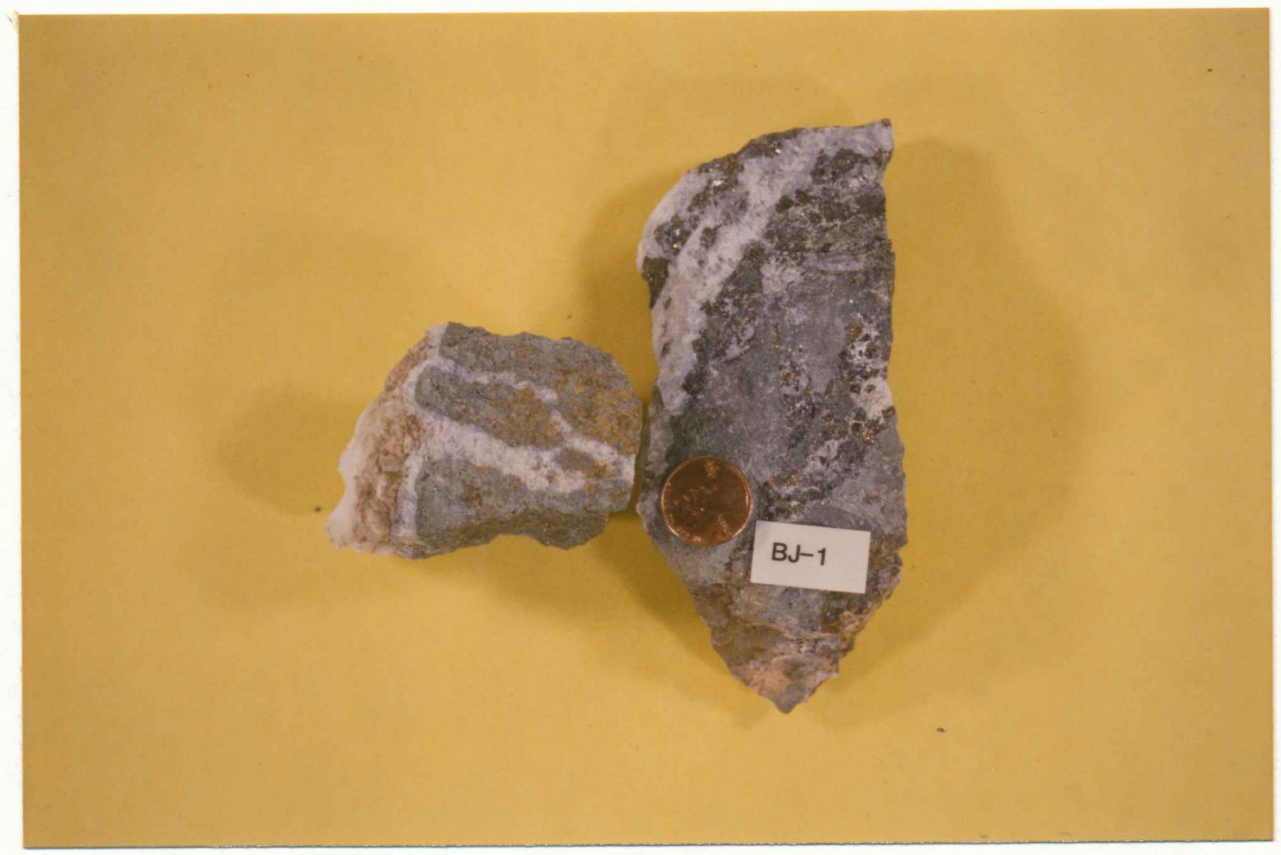

Figure 20. Photograph of vein sample from the Morning Star Mine.

1) Propylitic alteration of host andesite tuff 2a) Quartz, sericite, pyrite alteration

b) Euhedral quartz veining

3) Precipitation of base metal sulfides

4) Continued quartz veining

5) Brecciation

6) Calcite veining

Figure 21. Paragenetic sequence for mineralization of the vein sample illustrated in Figure 20 above. 
Sulfide minerals seldom grew in contact with the vein walls but may be surrounded by early quartz or may be grown in the open space between vein walls. Brecciation which followed quartz deposition apparently opened additional fracture surfaces and coarse grained calcite crystals completely or partially filled some of the open space.

A sample from a small vein located in Battle Ax Creek near the Morning Star Mine displays overgrowths of chalcedonic quartz following a second zone of fluid inclusions as shown in the photomicrograph in Figure 22. In this vein, sulfide deposition preceeded the precipitation of the chalcedony and is in contact with it in several

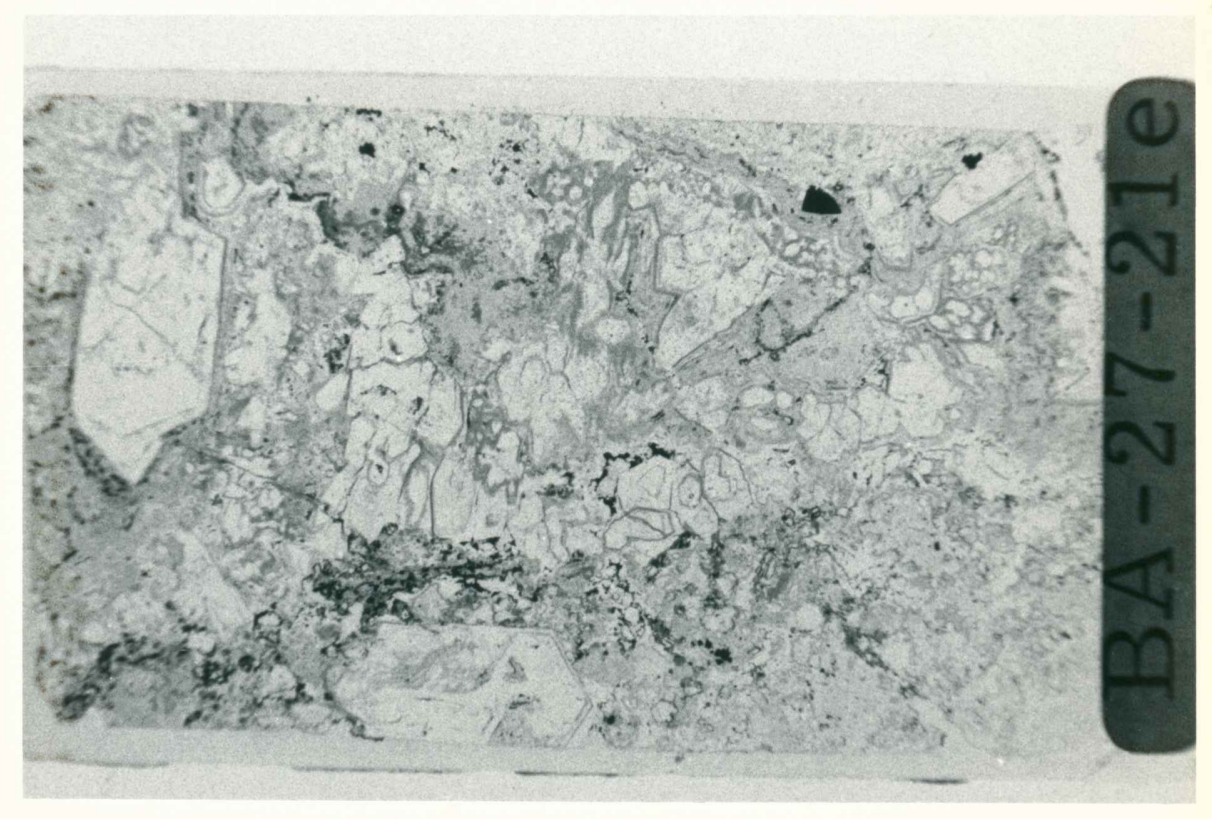

Figure 22. Photograph of thin section from quartz-chalcedony vein near the Morning Star mine. Note the development of chalcedonic silica on the faces of the large euhedral quartz crystal on left. 
places. Many veins show a second stage of fine euhedral quartz growth on the faces of the first stage and growing perpendicular to those faces resulting in a "porcupine" appearance.

Distribution of base-metal veins

The distribution of known mineralization is shown on Plates I, II, and III. Highest base-metal concentrations are found in veins of the Beuche Group, the Ruth Mine, and the Morning Star Mine. These three mineralized veins are localized along the $\mathrm{N} .40^{\circ}-50^{\circ} \mathrm{W}$. structural trend. They are the most abundant and contain the highest quantities of ore minerals in the vicinity of contacts between intrusions and the tuffs of unit A. In these three mineralized areas, sphalerite is the main ore mineral and galena is present in lower abundance. Pyrite is present in the veins, but is also found in other veins in which base-metal sulfides have not been detected. Chalcopyrite forms solitary grains and occurs as minute blebs commonly $0.05 \mathrm{~mm}$ in size within sphalerite grains (Figure 23 ).

Clay zones are common surrounding many quartz-calcite veins and reach thicknesses of $3 \mathrm{~m}$ or more in the Ruth Vein. They are thickest on the hanging-wall side of veins and may be totally absent in the foot walls. Many contain clasts of intensely altered wall rocks.

Mineralization in the Ruth Mine

The distribution of alteration zones and mineralization in the fifth level of the Ruth Mine is shown on Plate III. Base-metal sulfide mineralization dominated by sphalerite is located along northwesttrending faults, and the margins of the quartz-feldspar porphyry 


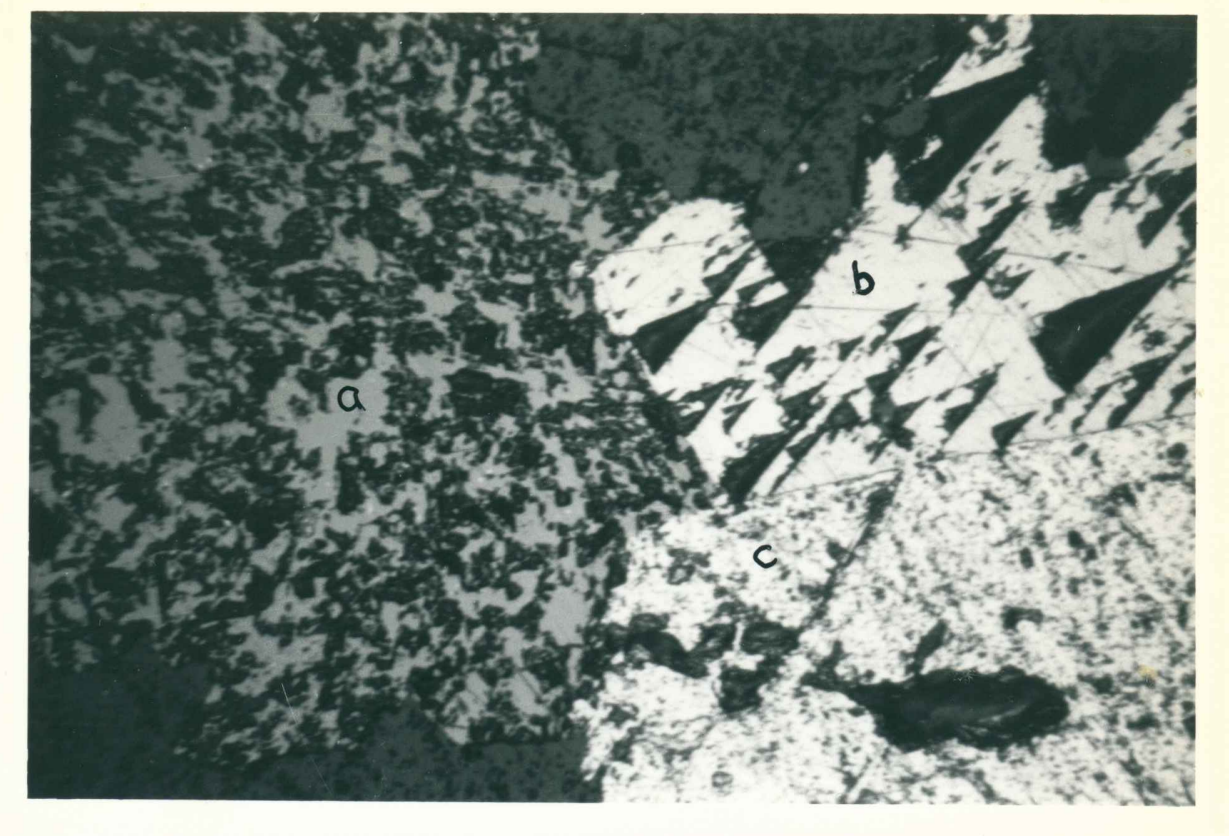

$23 a$

$23 b$

$$
\text { Reflected light. } 1 \mathrm{~mm}
$$

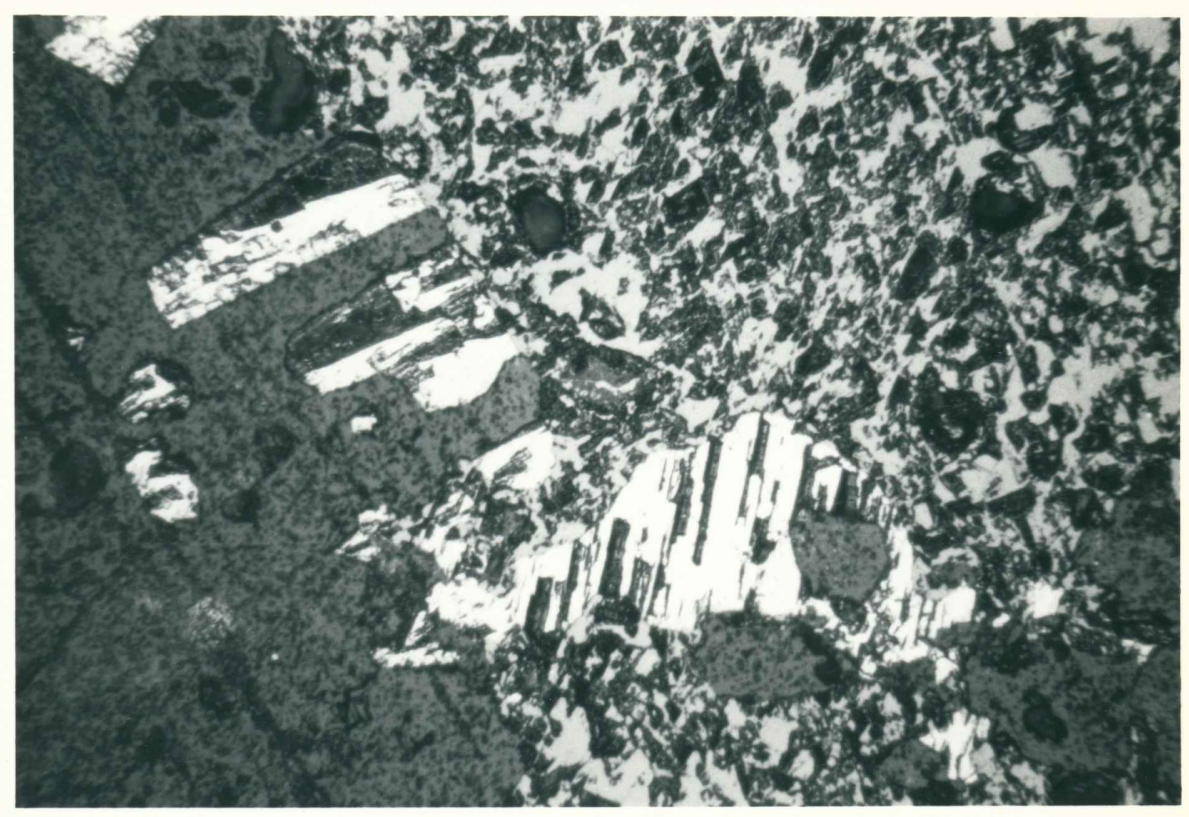

Figure 23. Ore texures from base-metal veins. Sphalerite (a), galena (b), and pyrite (c) are illustrated in this sample (R5-1050ST) from the Ruth Mine. Note the very fine light colored blebs of chalcopyrite intergrown with the sphalerite. Sample R2-4 (23b) contains less chalcopyrite. 
intrusion. Veins widen near the intersections of northwest structures and east-west structures. Sphalerite and galena are found with euhedral quartz in the open space "crackle" breccia developed in the intrusion, especially near the $1250 \mathrm{ft}$ point (Plate III).

The geometry of the quartz-feldspar porphyry in the mine is irregular with west-northwest margins tending to be low angle and southern margins, high angle. The hanging wall margin of the quartzfeldspar porphyry intrusion is interpreted as an intrusive breccia at three locations in the mine (640 ft, $860 \mathrm{ft}$, and $1030 \mathrm{ft}$ ) based on the large abundance of included host rock clasts (greater than $75 \%$ ). These intrusive breccias are tightly sealed and unmineralized.

The northwest-trending porphyritic diorite dike near the portal is sheared along a N. $10^{\circ} \mathrm{W}$. trend on its western margin and lacks distinctive alteration halos. Two northeast-trending andesite dikes are distinguished from the host fragmental rocks of Unit A based only on the presence of intense quartz-sericite alteration of the fragmental rocks along the margins. These alteration zones contain pyrite as the only identified sulfide mineral.

The mineralogy of one low-angle vein in the Ruth Mine was examined (Figure 24). Host rocks for the vein are a fragmental andesitic rock of Unit A. Crude color zoning in the clays is noted with a greenish-gray clay forming an envelope of 5 to $10 \mathrm{~cm}$ thick on the quartz-calcitesulfide vein. Higher in the hanging- wall, the clay is very light gray to white for 30 to $40 \mathrm{~cm}$. The hanging-wall contact of the clay zone and the andesite is sharp. The white clay is composed of kaolinite and sericite; the greenish clay, chlorite, kaolinite and sericite. Clays 


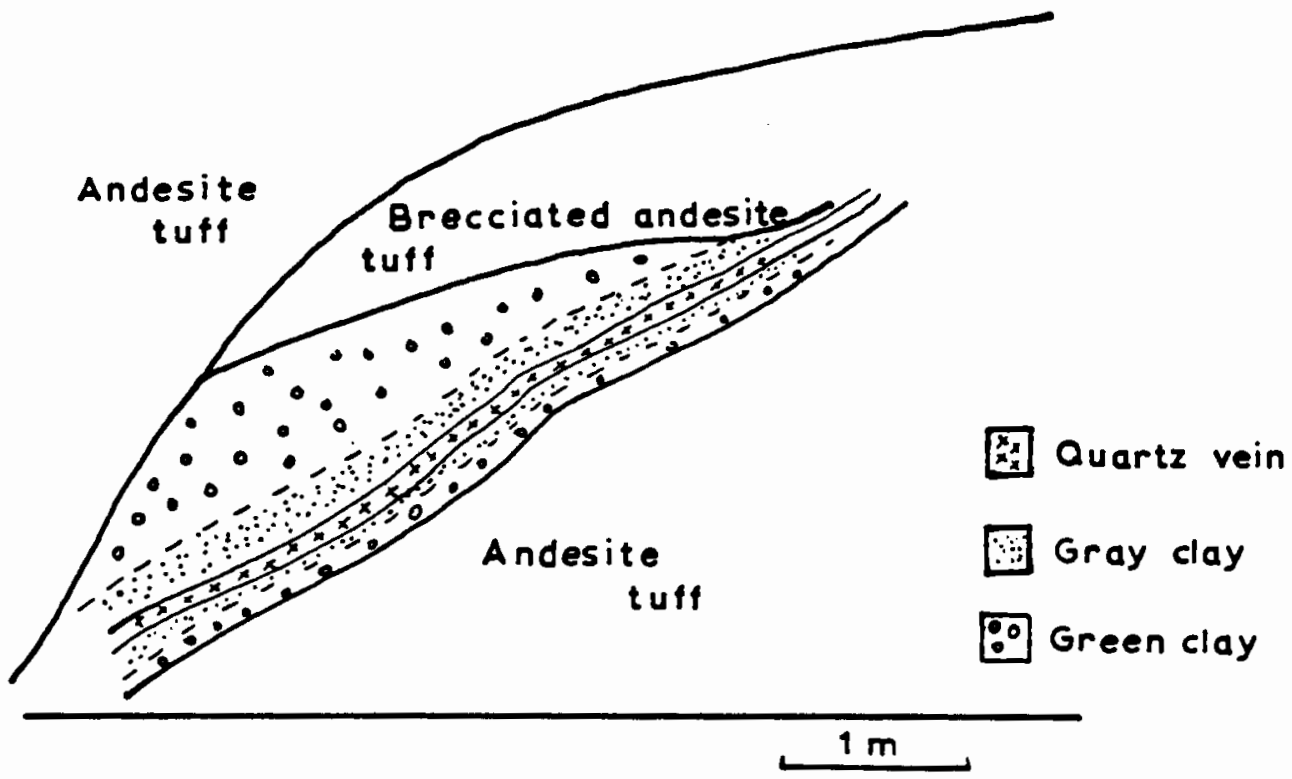

Figure 24. Sketch of a low angle vein in the fifth level of the Ruth Mine (R5-1290).

are well crystallized as evidenced by the ease in sample preparation and the sharpness of $x$-ray peaks. Swelling clays are not present in these samples. Greenish clay samples close to the vein contain numerous small (1-3 mm), euhedral gypsum crystals which were not detected in the whiter colored clay samples.

Fine needles of qypsum are found growing from the ceiling and walls of the adit along many veins in the Ruth Mine suggesting that they are forming from circulation of cold groundwater.

Samples of clays from several other locations in the mine have been $x$-rayed and contain varying percentages of the three clay minerals described above. 
Fluid inclusion data

Fluid inclusion data (Figure 25) has been obtained for quartz from 3 veins which display a phyllic alteration halo including, a small vein of the Morning Star group, a small vein on the western end of the Beuche group of claims, and a small prospect on the road in the NE1/4, SW $1 / 4$, Sec 28. Salinities are low with a freezing point depression range of $-0.8^{\circ}$ to $3.8^{\circ}$ which corresponds to 1 to $6 \mathrm{wt}$. \% $\mathrm{NaC} 1$ equivalent (Roedder, 1984). No daughter salts or other solid phases have been identified within the fluid inclusions. Homogenization temperatures are shown in Figure 25. Of these three veins only the Beuche sample site contains significant sulfide mineralization other than pyrite.

In addition, fluid inclusion data from euhedral quartz crystals collected from quartz-epidote veins cutting the equigranular diorite at the confluence of McCarver and Battle Ax Creeks are shown in Figure 25. Salinities of these inclusions are below 2 wt. \% $\mathrm{NaCl}$ equivalent. Homogenization temperatures are found to belong to several populations ranging in temperature from $250-310^{\circ} \mathrm{C}$. Base-metal sulfide mineralization is absent in these veins and pyrite is sparse. 


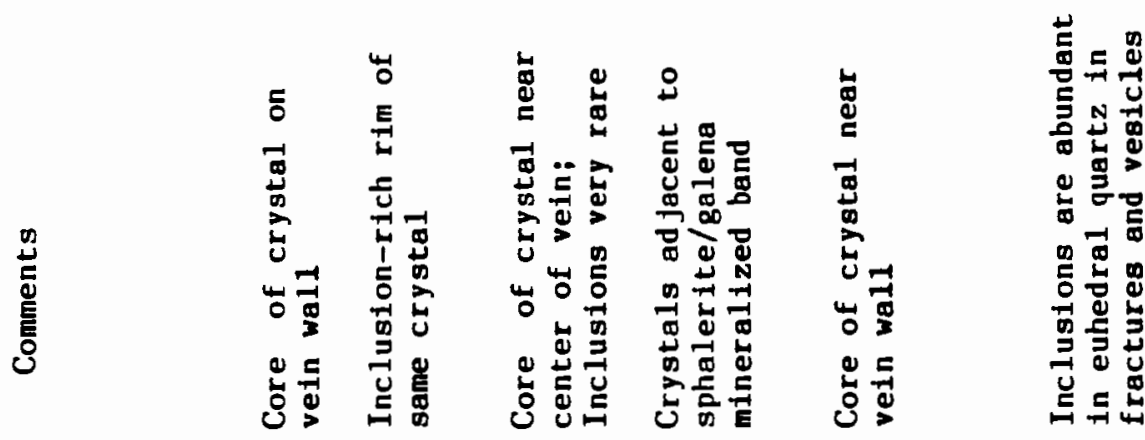

高

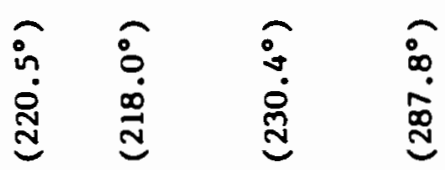

产

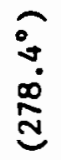

号

in $\stackrel{0}{\text { i }}$ i̊

กั้

\& 8 \&

ส

సิ

오

iิ

离

吝

$\stackrel{i}{i} \quad \stackrel{0}{i} \quad \frac{0}{i}$

$\therefore 28$

$\begin{array}{llll}0 & 0 & 0 & 0 \\ i & i & 0 & i\end{array}$

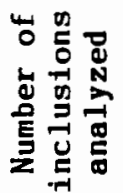

$\dot{\infty}$
$\dot{p}$
$\dot{1}$
0
0

ঙ্ণ

E

우

in

ปัّ

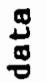

$\exists$

䢘

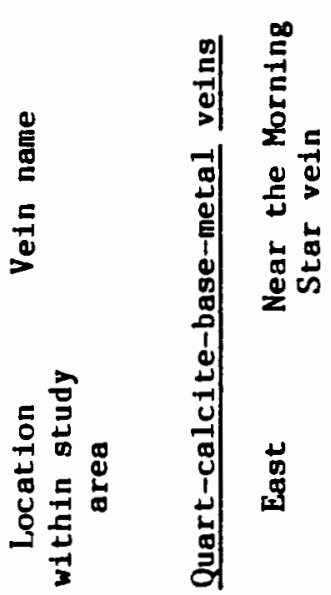

방

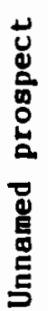

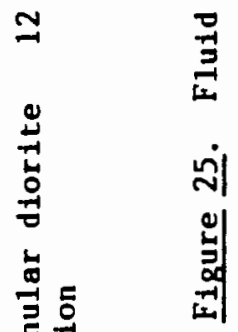

造

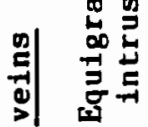

点

$\simeq$

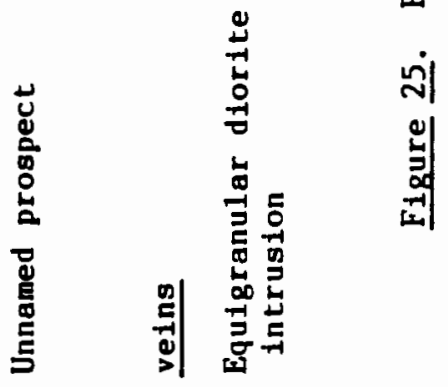

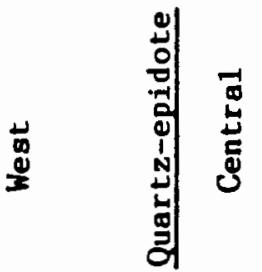




\section{CHAPTER V}

\section{GEOCHEMISTRY}

Instrumental neutron activation analysis (INAA) has been performed on selected samples of flows and tuffs from the stratigraphic sequence, intrusions, and alteration zones within the study area to assist in the correlation and characterization of rock units and alteration types. Irradiation of 1 gram samples was performed in the Reed College TRIGA Mark I research reactor at a nominal neutron flux of

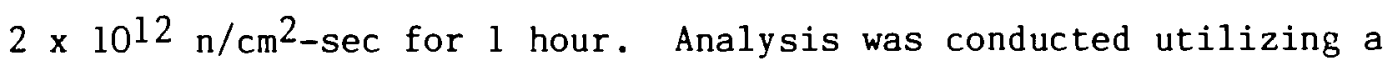
Tracor Northern TN4000 gamma spectrometry system. Decay times of 5 days and 30 days allowed determination of 20-24 elements. Concentrations of these elements in the samples were determined by comparison to USGS Standard rock samples. The complete data collected appear as Appendix C.

Rare Earth Elements (REE) were normalized to an average $\mathrm{Cl}$ chondrite (Ekambaram and others, 1984) the values of which are included with the data tables in Appendix C.

\section{"Unaltered" stratigraphic units}

Although an attempt was made to select the least altered samples for analysis, all samples collected had been subjected to weak to moderate alteration. Details on the alteration of specific samples appear in appendix $B$. 
Plots of $\mathrm{Na}$ relative to $\mathrm{Fe}$, and $\mathrm{Na}$ relative to $\mathrm{Sc}$ appear as Figure 26. In both cases, distinct groupings separate the flows of Unit B from the flows of Unit D with those of Unit D showing relatively lower $\mathrm{Na}, \mathrm{Fe}$, and Sc concentrations. Tuffs of Unit A plot with the flows of Unit B; the tuffs of Unit $C$ plot with the flows of Unit $D$. Samples of the quartz-bearing felsic (dacite) tuffs of questionable stratigraphic affinity (W-28-16a and WM-3) do not plot with either group. In addition, one tuff assigned to Unit C (B-35-8a) contains about twice the concentration of sodium as other Unit C and D samples. The incompatable elements Hf and La are plotted against Th (Figure 27). Again the flows of Units B and D plot within distinguishable fields. The nature of these fields suggests that there is a linear relationship between $\mathrm{La} / \mathrm{Th}$ and $\mathrm{Hf} / \mathrm{Th}$ in these samples. Samples of quartz-bearing tuffs (W-28-16a and WM-3) included as units of uncertain stratigraphic relationship do not plot within either field. In addition, two of the flows of Unit $D$ on Whetstone Mountain (WM-6 and WM-7) are separated from both groups although they plot very close to each other. The high concentration of La in one flow of Unit B (sample MR-35-8) is a function of the overall enrichment of REE in this flow.

Rare-earth element concentrations are plotted relative to chondrite for selected samples of flows of Units B and D (Figure 28). All flows fall within the ranges indicated by dashed lines except MR-35-8 which is significantly enriched in light rare-earth elements. 

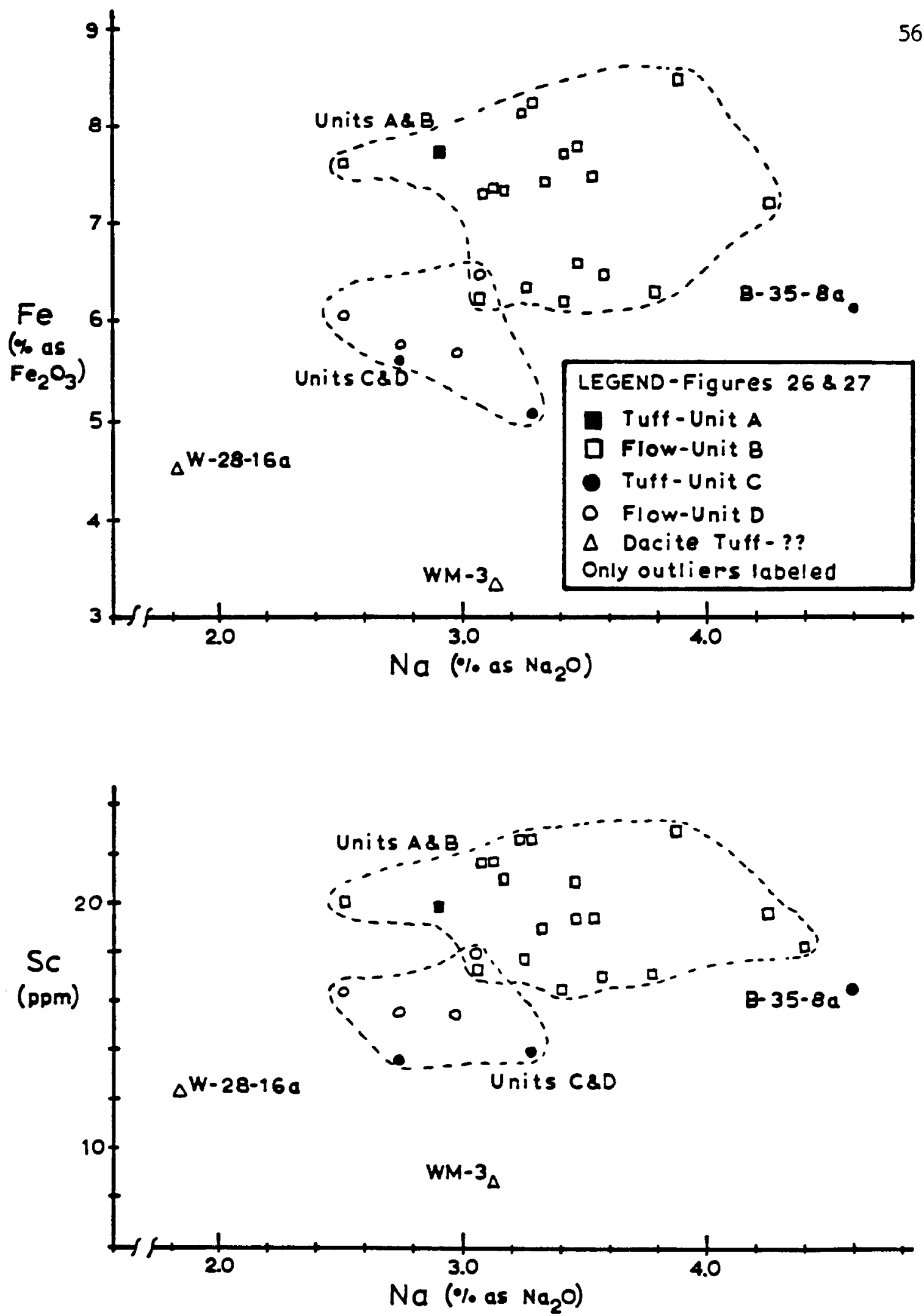

Figure 26 . Plots of iron (Fe) and scandium ( $\mathrm{Sc}$ ) against sodium $(\mathrm{Na})$ for rocks in the stratigraphic sequence. 

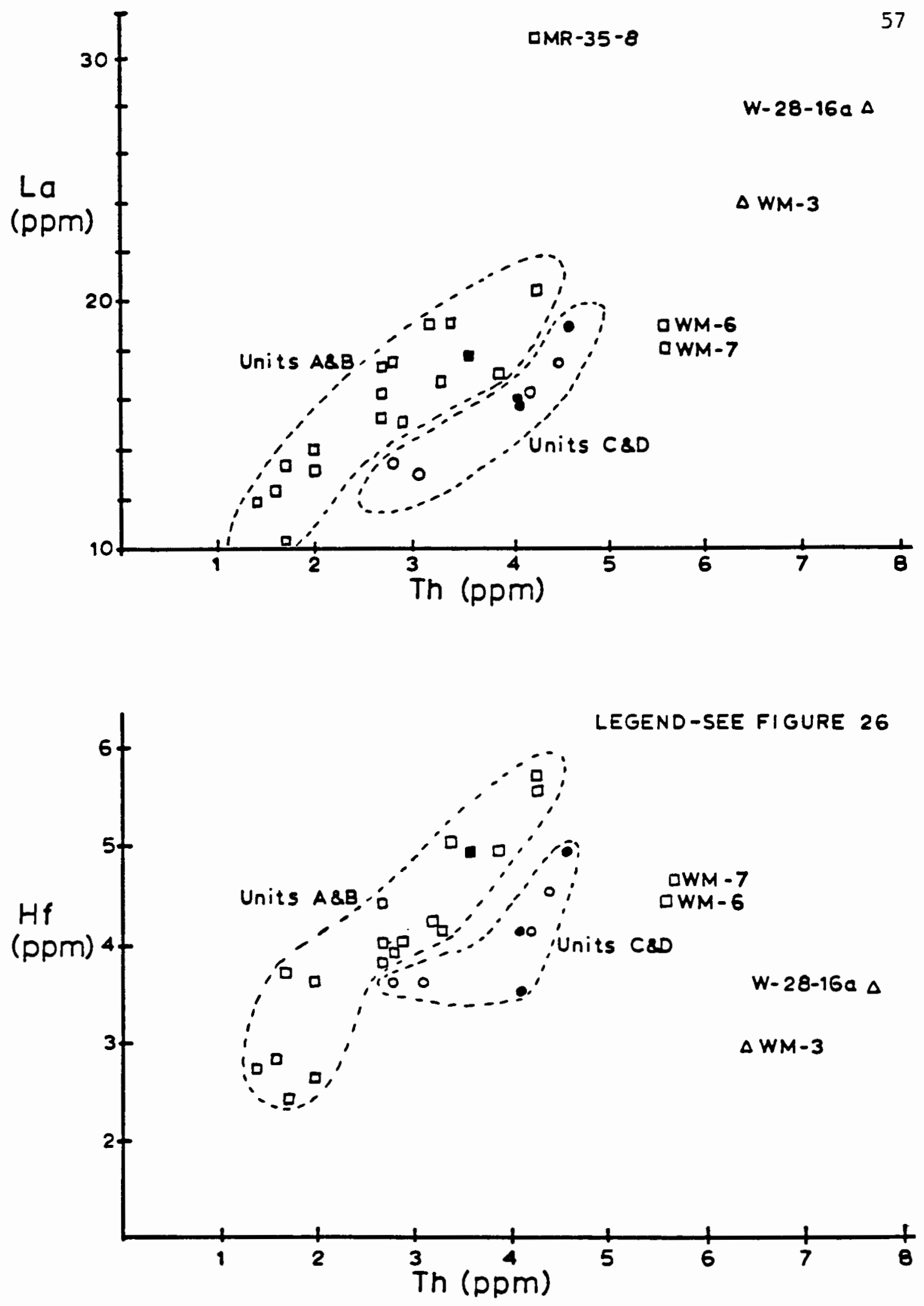

Figure 27. Plots of the incompatable elements lanthanum (La) and hafnium (Hf) against thorium (Th). 


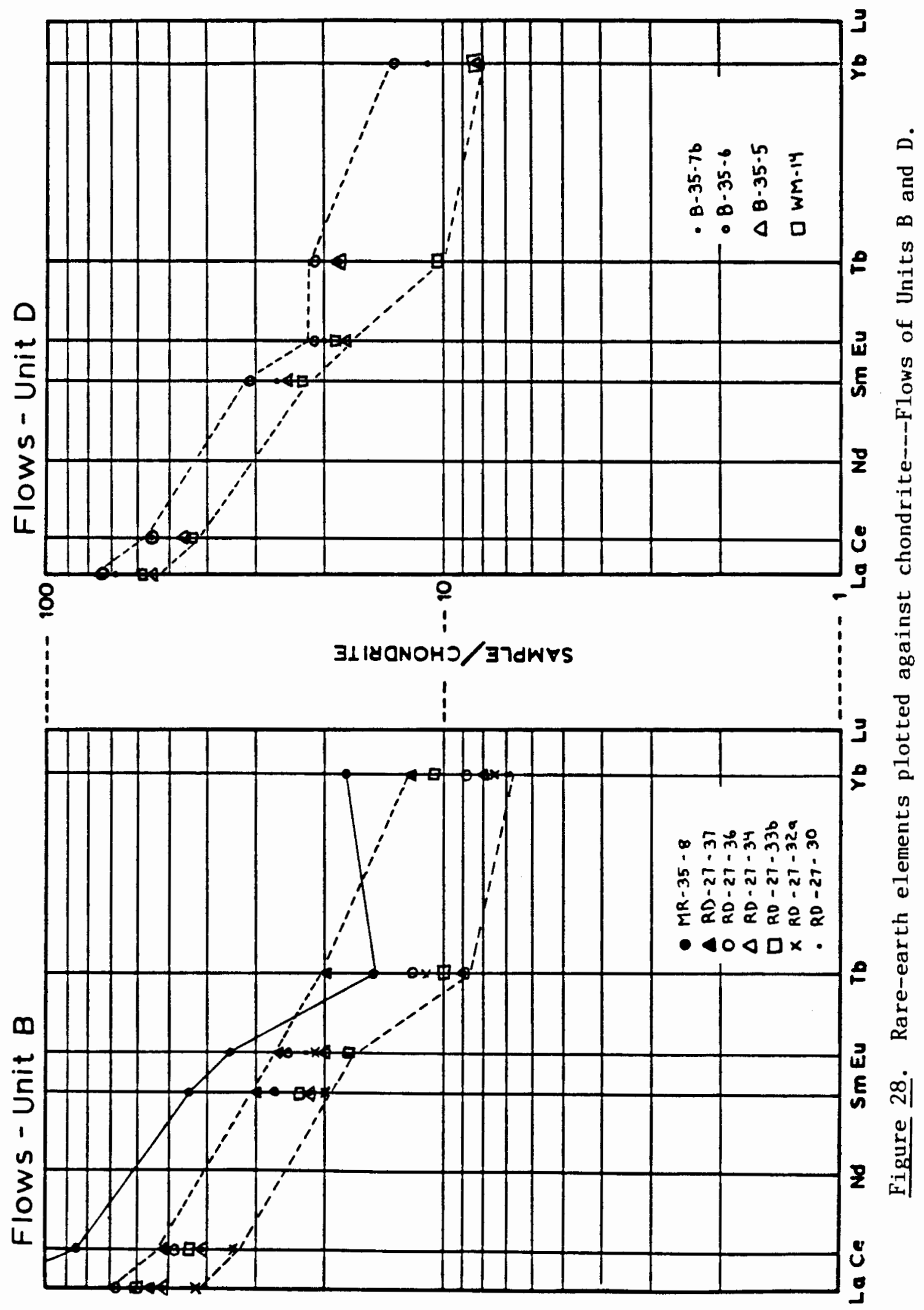


The tuffs of Unit A along with rocks of uncertain stratigraphic relationship are plotted on Figure 29a. All plots display moderate, light rare-earth element (LREE) enrichments typical of calc-alkaline andesites. Ratios of normalized concentrations of La to $\mathrm{Yb}$ range from 3.2-5.3 in Unit B and from 3.1-4.8 in Unit D. Europium displays either no anomaly relative to the rare earth element trends or has a small anomaly which may be either positive or negative. Ratios of normalized Sm to Eu range from $0.92-1.3$ in Unit $B$ and $1.2-1.3$ in Unit $D$.

\section{Intrusions}

Intrusions sampled are all moderately to intensely altered and interpretation of the REE patterns must be considered in that light.

\section{Quartz-feldspar porphyry}

All samples of the quartz-feldspar porphyry intrusion display significant LREE enrichments and strong negative europium anomalies (Figure 29b), enrichment in uranium, and depletion in iron relative to other rocks in the mining area. Europium anomalies show normalized $\mathrm{Sm} /$ Eu ratios of $4.1-6.2$.

\section{Porphyritic diorite}

Samples of propylitically and phyllically altered porphyritic diorite intrusions were also run for trace elements. Rare-earth element plots (Figure 30a) show moderate LREE enrichments similar to those for the andesitic extrusive rocks. The LREE enrichment in the porphyritic diorites is slightly greater than that in the equigranular diorites and neither show negative Eu anomalies. Upon alteration, 


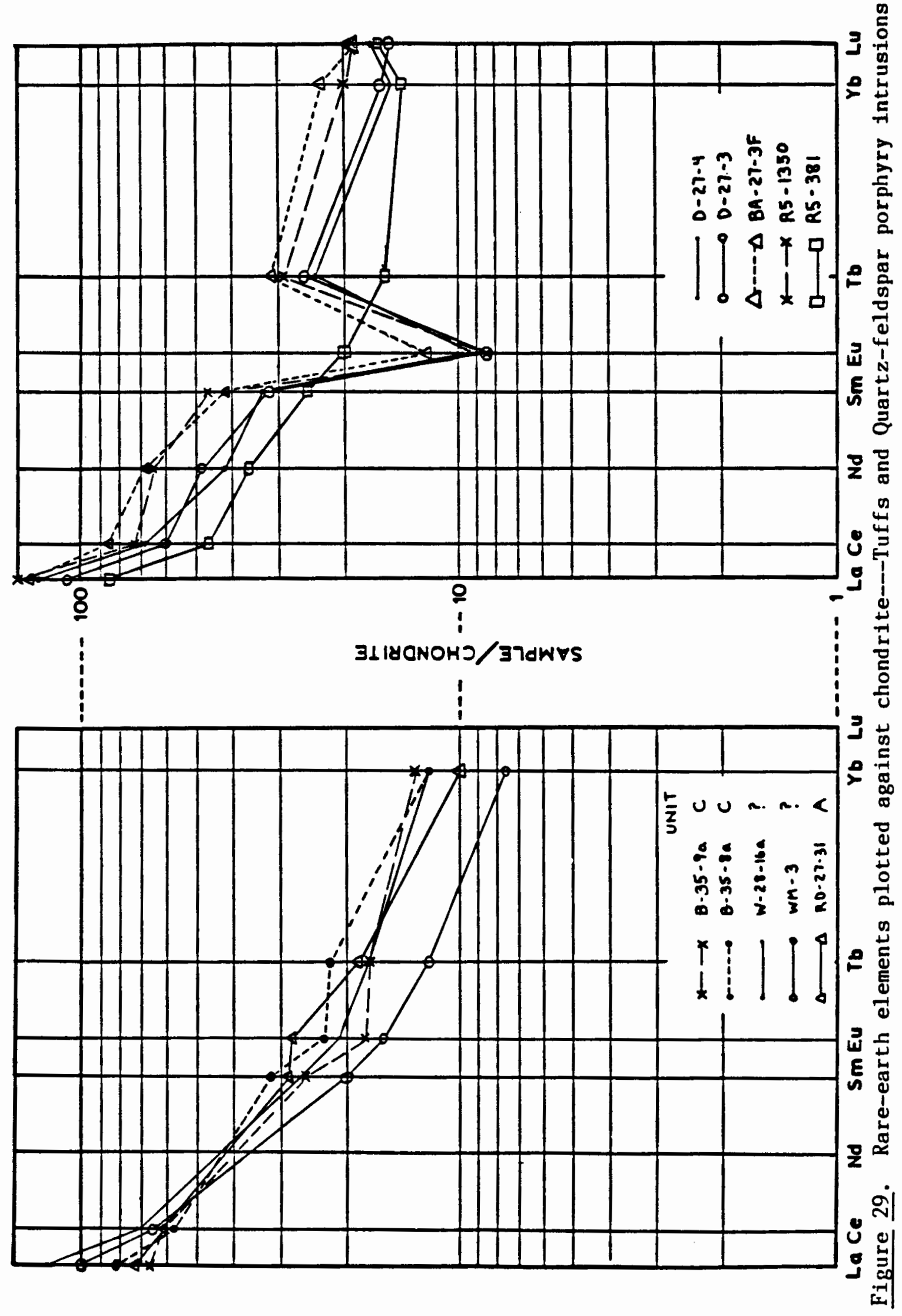




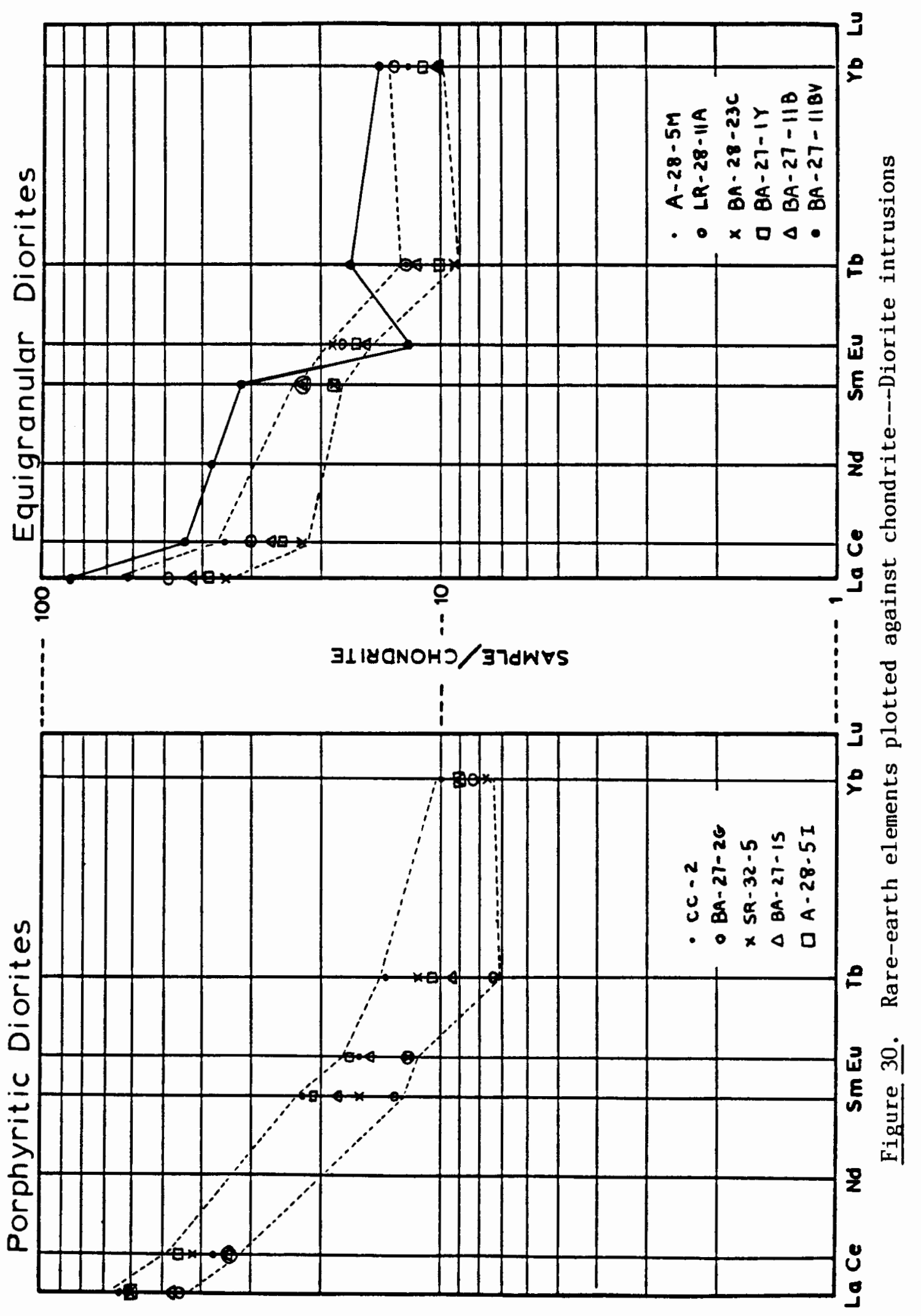


these rocks appear to faithfully preserve the REE patterns of the original rock with differences within the error of the analyses.

\section{Equigranular diorite}

Samples of the equigranular diorite have been subjected to minor to intense propylitic alteration and the developement of quartz-epidote veining is present in all intrusions analyzed. REE plots (Figure 30b) are consistant with other intrusion types discussed above. Sample BA-27-11BV is from an aplite vein cutting an equigranular diorite intrusion near the confluence of Henness and Battle Ax Creeks. This sample displays strong LREE enrichment and negative europium anomaly characteristic of the quartz-feldspar porphyry intrusions.

Geochemistry of alteration of a tuff of Unit $A$

The REE geochemistry of samples of the tuffs of Unit A have been examined in each of the three alteration types. It is believed that all analyzed samples are from the same unit immediately over-1ying the polymictic breccia. Descriptions of the samples appear in Figure 18. Analytical results appear in Appendix $C$ and are plotted on Figure 31 a.

Chondrite normalized REE patterns do not change significantly in samples displaying propylitic and phyllic alteration. They remain paralle1 to the unaltered rock. Sample $B A-28-2 e$ is from one of the breccia dikes in the base of the tuff and is intensely altered to clay. This sample displays REE patterns similar to argillically altered vein clays believed to be derived from the same tuff in the Ruth Mine (Figure 31b) which are significantly depleted in LREE relative to fresh or propylitically altered rock while the HREE are not depleted. 
63

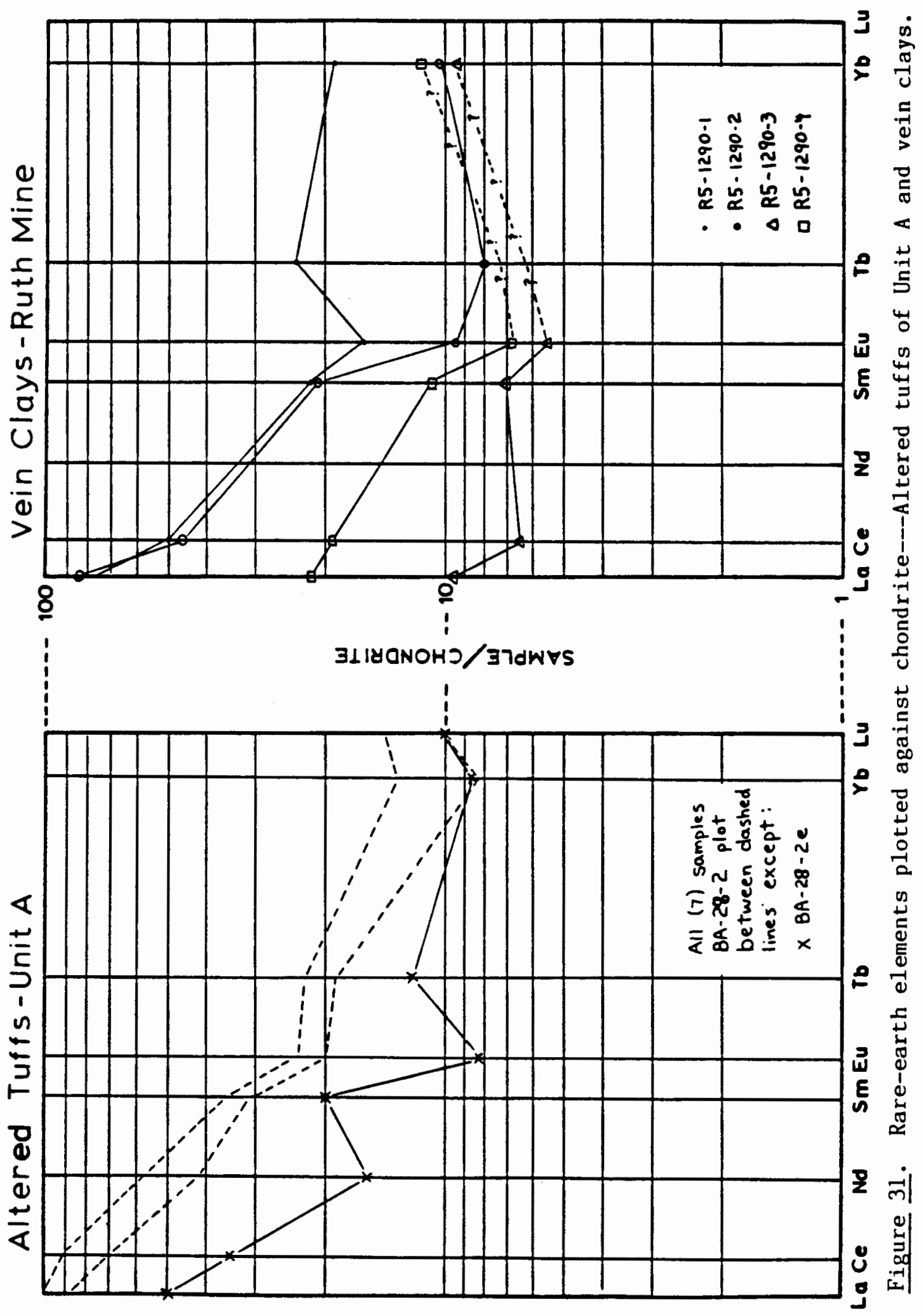




\section{CHAPTER VI}

\section{DISCUSSION}

Developing a model to describe the nature of those portions of a porphyry copper system between the magmatically dominated core and the paleosurface based on the data collected in the North Santiam requires: 1) examination of stratigraphic relationships and correlations with reported age dates; 2) examination of the intrusive history and its relationship to the mineralization and alteration; 3 ) analysis of the structural development relative to volcanism and mineralization; and 4) determination of the chemistry of the solutions responsible for alteration and mineralization at different times in the development of the system.

\section{Stratigraphic relationships}

Stratigraphic units in the area consist of gently dipping lava flows and tuffs. All of these units were originally assigned to the Sardine Formation by Peck and others (1964). As used by Peck and others (1964), the Sardine Formation contains a wide range of lithologies and covers a large geographic area. Subsequent workers (White, 1980a, 1980b; Dyhrman, 1976; Hammond and others, 1982; and Priest and others, 1983) in the Western Cascades in northern Oregon have recognized the need for defining smaller units. While the thrust of the present study has not been the resolution of stratigraphic 
problems and the application of unit names has been avoided, several observations and suggested correlations with previous small scale mapping in the region are valuable and are summarized on figure 32 .

Olson (1978) divided the stratigraphic sequence found in the mining area into an upper and lower member and assigned both to the Sardine Formation of Peck and others (1964). Since 0lson (1978) described his lower member of the Sardine Formation as being composed primarily of lava flows, it is assumed that it includes both Unit $A$ and Unit $B$ of the present study. This agrees with his mapping of the contact south of Battle Ax Creek in sections 27 and 28. Olson did not recognize the presence of tuffs described herein in Unit A. This is understandable due to the alteration of these tuffs including the destruction of primary textures prevalent especially in areas near large intrusions.

The lowest member of Unit A was postulated by 01son (1978) to have been a breccia of mudflow origin. He believed that it corresponded to a mudflow with a thickness of greater than $100 \mathrm{~m}$ (300 ft) reported by Callaghan and Buddington (1938). Statistical evaluation of clast sizes by Olson (1978) suggested a source to the southeast. No attempt was made in the present study to confirm this postulation. The presence of parallel sided, steeply dipping zones of sorted breccia material which cross-cut both this unit and the overlying fine-grained tuff unit has not been previously reported. It is suggested that this evidence requires essentially simultaneous deposition of both units. If the polymictic breccia were a lahar, these disruptions could be clastic dikes resulting from the loading of 

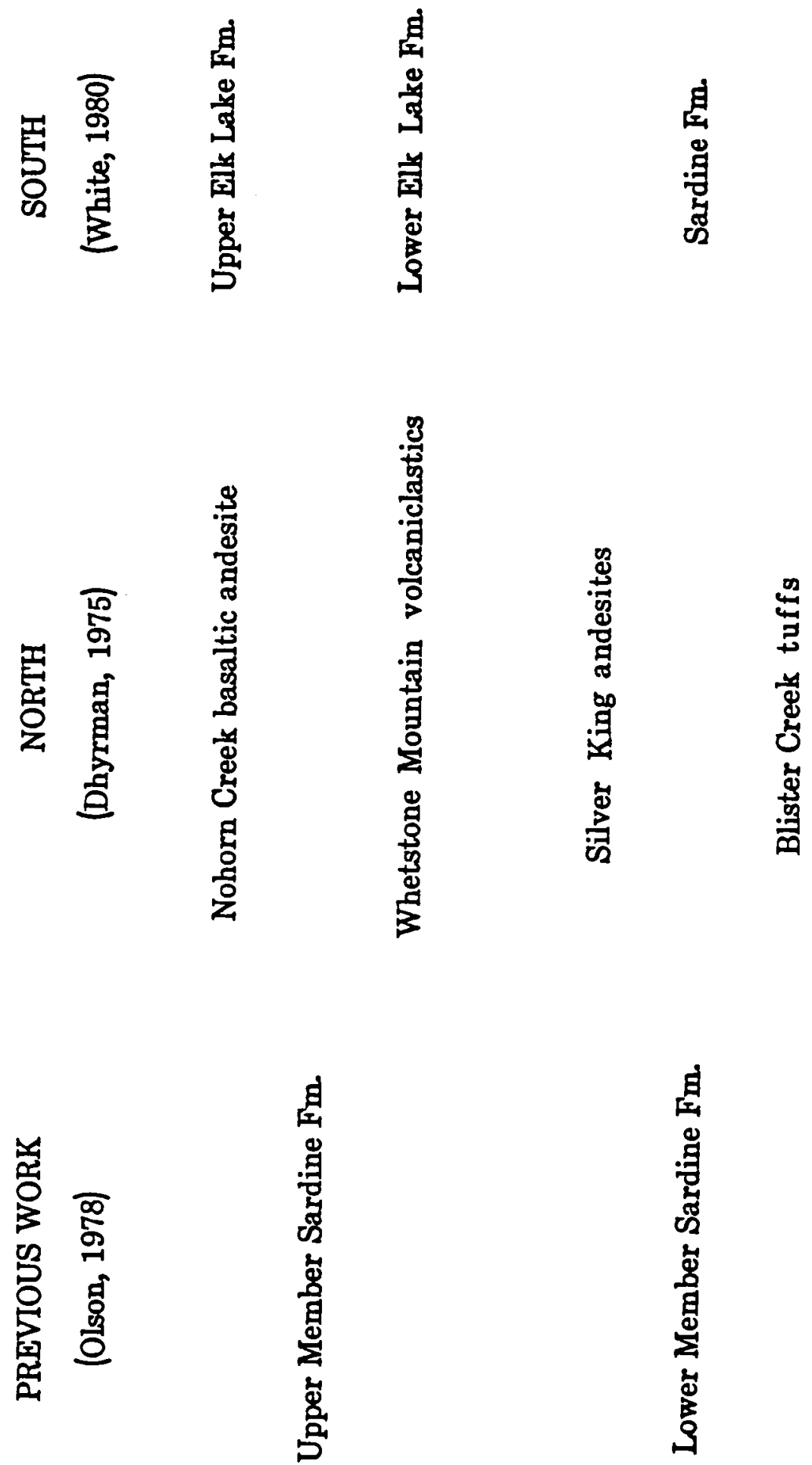

芒

范

$\underset{-1}{-1}$

告

悬

लें|

点 疍

A

0

m

4 
a wet mudflow by the tuff which was at least $35 \mathrm{~m}$ thick. The favored hypothesis is that the breccia is not a lahar but rather the central, block breccia portion of a thick block and ash flow deposit while the overlying finer grained fragmental rock is the upper portion of the same cooling unit. Gas escape structures are reported to occur in this setting from modern deposits at Mt. Pelee (Fischer and Schminke, 1984) where they have dimensions ranging from $10 \mathrm{~cm}$ to $10 \mathrm{~m}$ in length and 1 $\mathrm{cm}$ to $30 \mathrm{~cm}$ in width. Modern deposits lack matrix and the resulting open vertical permeability could explain the locally intense alteration along these fractures. If this latter postulation is correct, this cooling unit may be in excess of $125 \mathrm{~m}$ in thickness. In either case, 01son's (1978) postulation of a source to the southeast would seem to be valid.

Dyhrman (1976) mapped the north side of Whetstone Mountain as high as the fragmental rocks of unit $\mathrm{C}$ and direct correlation of units is therefore possible. He assigned to the fragmental rocks of unit $\mathrm{C}$ the name of Whetstone Mountain volcaniclastic rocks. They are reported to be underlain on Whetstone Mountain successively by the Thunder Mountain andesite, the Silver King andesite, and the Blister Creek tuff. The flows assigned by Dyhrman to the Thunder Mountain andesite and the Silver King andesite are described as being similar porphyritic andesites and basaltic andesites. The Thunder Mountain andesite is a single flow distinguished by Dyhrman (1976) on the basis of characteristic columnar jointing. Otherwise the two units are similar in composition and are described as displaying a red platy appearance. Based on the similarity of appearance, mineralogy, and chemistry among 
these flows, they are included together as unit $B$ in this study and correlate directly along the northern boundary of the current study area.

Blister Creek tuffs (Dyhrman, 1976), which underly the flow sequence of the Silver King andesite, are pumice-lapilli tuffs with plagioclase crystals in the matrix. In the upper Clackamas River drainage they are found in stream beds where they commonly develop "chutes" and "pot-holes" (Dyhrman, 1976) similar in appearance to those seen in the breccia member of Unit A in this study. Dyhrman (1976) did not map the top of Whetstone Mountain, however, north of this point 6.4 and $8.0 \mathrm{~km}$ he mapped two outcrops of a very dark colored porphyritic basaltic andesite which he reported was deposited as an intracanyon flow into the Silver King andesite (Dyhrman, 1976). The name assigned to this unit was the Nohorn Creek basaltic andesite. 01son (1978) also did not map the dark lavas on top of Whetstone Mountain separately from his upper member, however, two ridge top outcrops of dark basaltic andesite were mapped along the southern boundary of sections 31 and 32 . These were interpreted by Olson (1978) to be intrusions based on the steep dip of their contacts with a tuff. Whether these are intrusions or intracanyon flows needs to be further investigated. Based on the extensive nature of the dark lavas identified in the present study, it is postulated that Unit $D$ was deposited on a relatively mature topography with the first flow or flows filling existing canyons and subsequent flows developing a wider lateral extent. 
White (1980b) mapped in the area of French Creek Ridge about 6.4 $\mathrm{km}$ to the south of the current study area. In that area, the E1k Lake Formation was defined as consisting of a lower member of hornblende dacite and rhyodacite tuffs and flows and an upper member consisting of andesite to basaltic andesite flows. Age dates on rocks of the E1k Lake Formation range from 11.8 to $11.0 \mathrm{~m} . \mathrm{y}$. B.P. A vent complex for this formation was identified on French Creek Ridge. White (1980a) reported that the Elk Lake Formation overlies rocks of the Sardine Formation and the Breitenbush Tuff. To the southeast of French Creek Ridge, the E1k Lake Formation is reported to overly the other units at a "profound angular unconformity". Flows of the upper Elk Lake Formation are described as being very dark, somewhat glassy lavas similar to the flows of Unit $D$ in the present study.

In an unmapped area west of French Creek Ridge, is a bedded pyroclastic deposit of probable rhyodacitic composition (Cummings and Pollock, 1984). Individual beds are from 5 to $10 \mathrm{~cm}$ thick and are distinguished by alternating light and dark layers. Based on the elevation and apparent stratigraphic position, this is believed to be a member of White's (1980a, 1980b) lower E1k Lake Formation. In addition, it is suggested that this may be the proximal facies of a surge deposit, the distal facies of which is exposed as the finely laminated member of Unit $C$ in the present study. If this postulation is supported by further mapping, this deposit would serve as a valuable time-stratigraphic marker. 
Intrusive History

Age relationships among the intrusions in the mapped area are not clear. Olson (1978) postulated that the quartz-feldspar porphyry intrusion was the oldest intrusion in the area based on a reported cross-cutting relationship in the vicinity of the Ruth Mine. No crosscutting relationship was observed in the present study and 01son's conclusion is believed to be incorrect.

Equigranular and porphyritic diorite intrusions always occur as northwest-trending dikes and have not been observed to cross-cut one another. Although the contacts between the quartz-feldspar porphyry and the other intrusions are poorly exposed, the general geometry of these intrusions shown on Plate II, suggests that it is the youngest of the intrusive types. This hypothesis is supported by the presence of aplite veins which cross-cut the equigranular diorite near the confluence of Henness and Battle Ax Creeks. Aplite veins and quartzfeldspar porphyry intrusions display similar trace element signatures including large negative europium anomalies. Although no extrusive rocks have been identified which display similar trace elements the nature of the columnar jointing on Whetstone Mountain suggests that the quartz-feldspar porphyry intrusion may have vented at a paleosurface close to that of the other silicic tuffs of Unit C.

All identified intrusive contacts in the current study area are against tuffs of Unit A. To the west, both 0lson (1978) and Dyhrman (1976) show porphyritic diorite intrusions penetrating the flows correlative with Unit B. In no case is there evidence that any of these intrusions penetrate Units $C$ or $D$. 
Structural development

Dips decrease with increasing stratigraphic position suggesting the development of northeast-trendjing folding beginning prior to the development of the Unit A/Unit B contact and continuing through initial deposition of Unit D. Dates obtained by White (1980b) on correlative units in the vicinity of French Creek Ridge place the time of folding in the range of $17-11 \mathrm{~m} . \mathrm{y}$. B.P. Thinning of units to the northwest may have been the result of: 1) deposition against a developing topographic and structural high, or 2) increasing distance from a volcanic source or sources to the southeast. Findings of the current study do not support the presence of a pronounced angular unconformity in the study area such as that reported by White (1980b) in the area to the southeast.

Faulting along a N. $30-40^{\circ} \mathrm{W}$. trend preceeded and controlled the emplacement of the diorite intrusions including those believed to be genetically related to that for which a date of $13.4 \mathrm{~m} . \mathrm{y}$. B.P. has been reported (Power and others, 1981a). Movement on these faults continued through the time of mineralization as evidenced by the brecciation of veined samples in the Morning Star Mine.

Faulting on the N. $80^{\circ}$ E. structural trend may have begun while northwest faulting was still active, however, it clearly continued afterwards as evidenced by the lateral offset noted on many veins and structures in the area.

North-south to $\mathrm{N} .10^{\circ} \mathrm{W}$. faulting is the youngest major structural feature in the area and crosscuts all volcanic units. It is postulated that this faulting is related to the uplift of the Western 
Cascades and the development of the Cascade graben which is reported to have occurred about 5 M.Y. (Priest and others, 1983).

\section{A1teration and mineralization}

Development of a propylitic alteration assemblage can occur at either high or low water to rock ratios. At low ratios, the assemblage albite, epidote, and chlorite with or without quartz may be produced by isochemical recrystallization of the original rock forming minerals. This process occurs in the greenschist facies of regional metamorphism and is discussed in numerous metamorphic petrology texts (eg. Turner, 1981). At higher water to rock ratios, Giggenbach (1984) argues that $\mathrm{Na}^{+}, \mathrm{Mg}^{+}$, and $\mathrm{Ca}^{++}$metasomatism produces propylitic alteration assemblages as the result of the interaction between host rock and descending, heating hydrothermal fluids.

The nature and distribution of the propylitic alteration in the North Santiam suggests that both processes were involved. Development of chlorite and epidote after primary minerals is pervasive through the rock fabric of flows, tuffs, and intrusions in the study area irrespective of expected primary permeability. It decreases in intensity with increasing elevation and is absent in the upper flows of Unit D. Lower in the section, it is present throughout the area, except where phyllic or argillic alteration is noted, and is believed to extend well beyond the study area in those units. This pervasive propylitic alteration is postulated to be the result of isochemical recrystalization and hence is essentially metamorphic in character. It results from a combination of burial depth and elevated geothermal 
gradients during periods of active intrusion and volcanism.

Locally, calcite-chlorite veinlets high in the system and quartzepidote veinlets and vesicle fillings lower in the system are accompanied by halos of chlorite with or without epidote. This suggests alteration resulting from the movement of significant water volumes through fractures, faults, and vesicles. Based on the conclusions of Giggenbach (1984), it is postulated that these areas represent recharge zones for the hydrothermal system. They are best developed in the equigranular diorite intrusions where fracture permeability and an abundance of vesicles apparently provided a channel for the vertical transport of solutions.

The development of phyllic alteration assemblages requires the addition of potassium to the rock from hydrothermal solutions. Conversion of plagioclase to sericite occurs by hydrogen and potassium metasomatism. Giggenbach (1984) calculated that potassium metasomatism results as hydrothermal fluids are cooling and that as a consequence phyllic and more importantly potassic alteration occur in upflow zones of geothermal systems. Potassic alteration, represented by the development of secondary potassium feldspars and biotite, has not been identified in the current study area but is reported in the area immediately to the west (01son, 1978; Dodd and Schmidt, 1982). Areas of phyllic alteration developed as alteration halos along northwesttrending structures, at margins of intrusions, and within the quartzfeldspar porphyry, are numerous in the study area and are associated with the deposition of quartz and base-metal sulfides in veins. Phyllic alteration halos are significantly larger within tuffs than 
they are in flows suggesting that the tuffs had greater porosity. Since metalization does not occur in the alteration halos within the tuffs, it is suggested that the early alteration lowered their porosity and confined subsequent vertical fluid movement to faults, major fractures, and within brecciated intrusions.

Quartz is found to be present and to be the stable silica form throughout most alteration zones associated with medium to high temperature hydrothermal ore deposits. Arnorsson (1978) reported that in the active geothermal fields of Iceland all solutions are saturated with respect to one of the silica polymorphs. Quartz solubility controls fluid silica concentrations at temperatures above $180^{\circ} \mathrm{C}$ whereas chalcedony controls concentrations below $110^{\circ} \mathrm{C}$. Between these temperatures either form may be stable and the controlling factors are not well defined. Where thermal fluids exceed $150^{\circ} \mathrm{C}$, dilution with cold groundwater may result in the supersaturation of the solutions with respect to chalcedony and hence its precipitation (Arnorsson, 1978). Fluid inclusions from the quartz-chalcedony vein in the Morning Star group reveal quartz formation temperatures prior to precipitation of chalcedony in the range of $205-240^{\circ} \mathrm{C}$. This suggests that this vein near the eastern edge of the mining area represents a site in the mixing zone of the hydrothermal fluids with cold ground water.

Development of mineralization in base-metal veins postdated the development of $\mathrm{N} .40^{\circ}-50^{\circ} \mathrm{W}$. faults and the emplacement of the northwest-trending diorite intrusions. It was concurrent with or followed development of $\mathrm{N} .80^{\circ} \mathrm{E}$. faults and intrusion of the quartzfeldspar porphyry and preceeded the N. $10^{\circ} \mathrm{W}$. to north-south faulting. 
Pervasive propylitic alteration resulting from isochemical recrystalization preceeded, at least in part, the development of phyllic alteration and quartz-base-metal veining as evidenced by the brecciation of propylitically altered volcanic host rocks prior to mineralization of some samples.

The temperature conditions under which alteration associated with the quartz-epidote veins occurred are in the same range as those at similar statigraphic positions in veins associated with phyllic alteration and base-metal mineralization. This suggests that these downflow zones may have been active at the same time as the base-metal mineralization.

Argillic alteration, characterized by kaolinite and gypsum, suggests that a period of alteration by more oxidizing solutions occurred after base-metal mineralization and phyllic alteration had ceased. This may have resulted from a lowering in the relative stratigraphic position at which boiling was occurring either as a result of erosional unroofing or a change in the groundwater hydrologic system.

\section{$\underline{\text { Mode1 }}$}

Figure 33 contains a summary of the postulated chronological development of the mining area. Correlation of Units $C$ and D with extrusive rocks from a volcanic center located on French Creek Ridge along with the similarity in age dates for these units (11.8-11.0 m.y. B.P.; White, 1980b) and alteration in the mining district (11.0 m.y. B P.; Power and others, 1981a) suggests the development of a model 


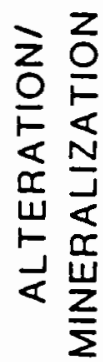

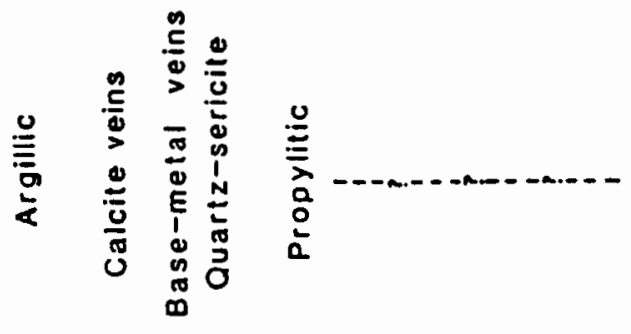

言

米

$\bar{z}$
0
0
$\bar{y}$
$\bar{s}$
0
0
0
0
$w$
0
0

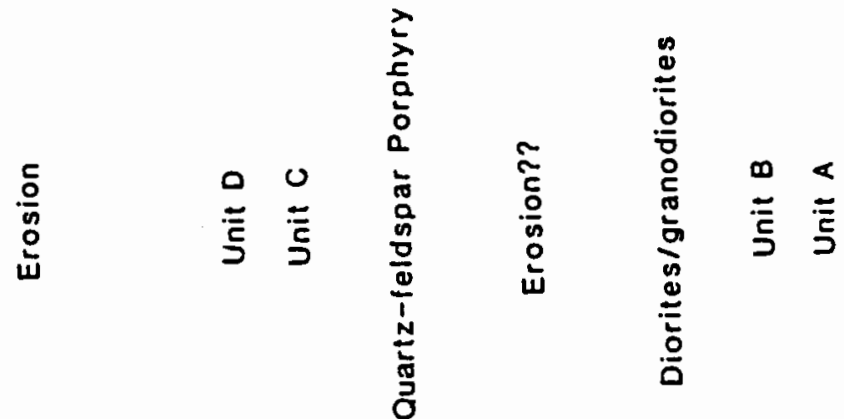

3
$\frac{2}{5}$
$\frac{1}{2}$
$\frac{1}{2}$

$\frac{\mathscr{L}}{2}$

드

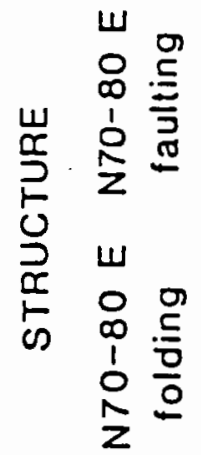

$\stackrel{0}{2}$

름

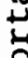

官

$\stackrel{0}{5}$

岁

3

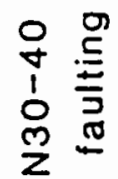

疍 
based on a modern Cascade composite volcano.

In order to illustrate the scale involved, Figure 34 shows a scale map of the outline of the Holocene deposits from Mt. Hood superimposed on the mining area with the peak of Mt. Hood centered on French Creek Ridge. The overlay has been rotated in order to superimpose Swim Warm Springs, located on the south flank of Mt. Hood, into a common position with the mineralization in the North Santiam. The flows of Unit D and correlative deposits mapped by Dhyrman (1976) and White (1980b) are shown. The flow identified on the top of Whetstone Mountain, the isolated outcrops to the north, and the lower flows south of Battle Ax Creek were deposited as intracanyon flows.

Fluid inclusion data supports this model. Figure 35 repeats the cross-section of the Ruth Mine area on which the temperature-depth to boiling curve as calculated using the procedure of Henley and others (1984) has been superimposed. On Figure 35, each temperature is given at the position of a paleosurface required to produce sufficient pressure to just prevent boiling. Evidence for boiling has not been noted during the analysis of fluid inclusions in the present study, thus these depths represent minimum distances to the paleosurface. As can be seen on this cross-section, the paleosurfaces projected from fluid inclusions are at elevations consistant with Units C or D.

This model locates only the paleosurface but does not address the possible sources of heat driving the hydrothermal system in the North Santiam at $11 \mathrm{~m} . \mathrm{y}$. B.P. Possible heat sources include late cooling of the diorite intrusions, the quartz-feldspar porphyry intrusion, or intrusions on French Creek Ridge. 


\section{MODEL}

\section{Legend}

x:yt Hood andesite flows

(on overlay)

Unit $D$ flows and

equivalents

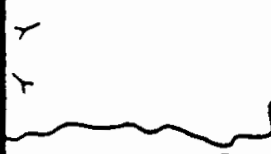

Little Nor in Sontiom $\mathrm{T} 8 \mathrm{~S}+\mathrm{Cu}$

T 95
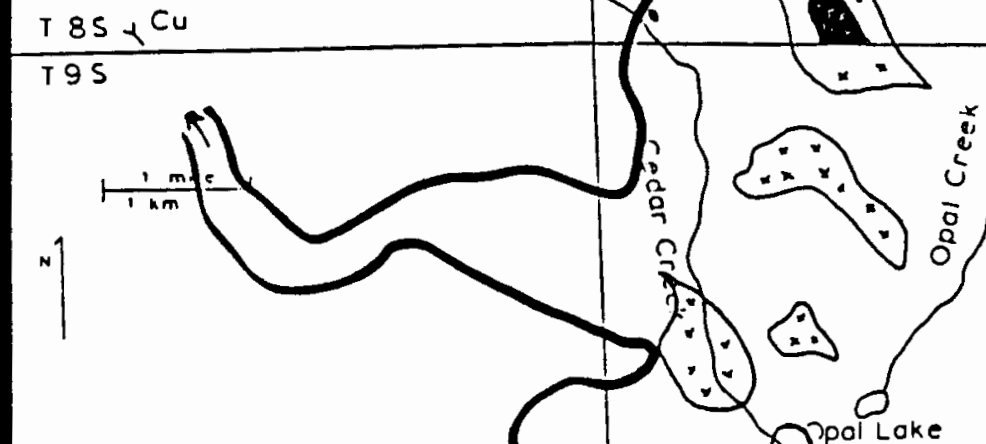

WHETSTONE MTN

8
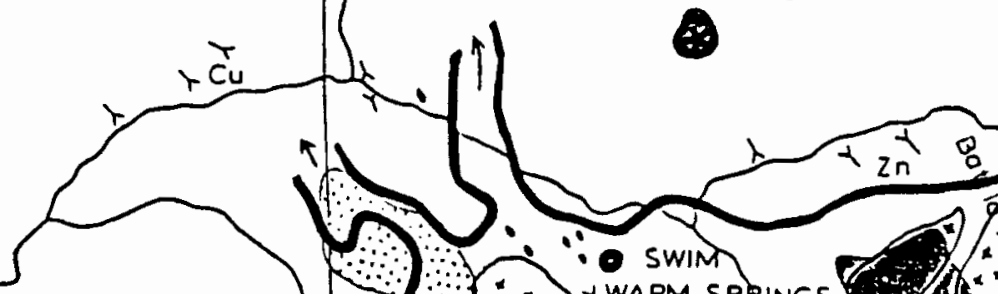

* * WARM SPRINGS
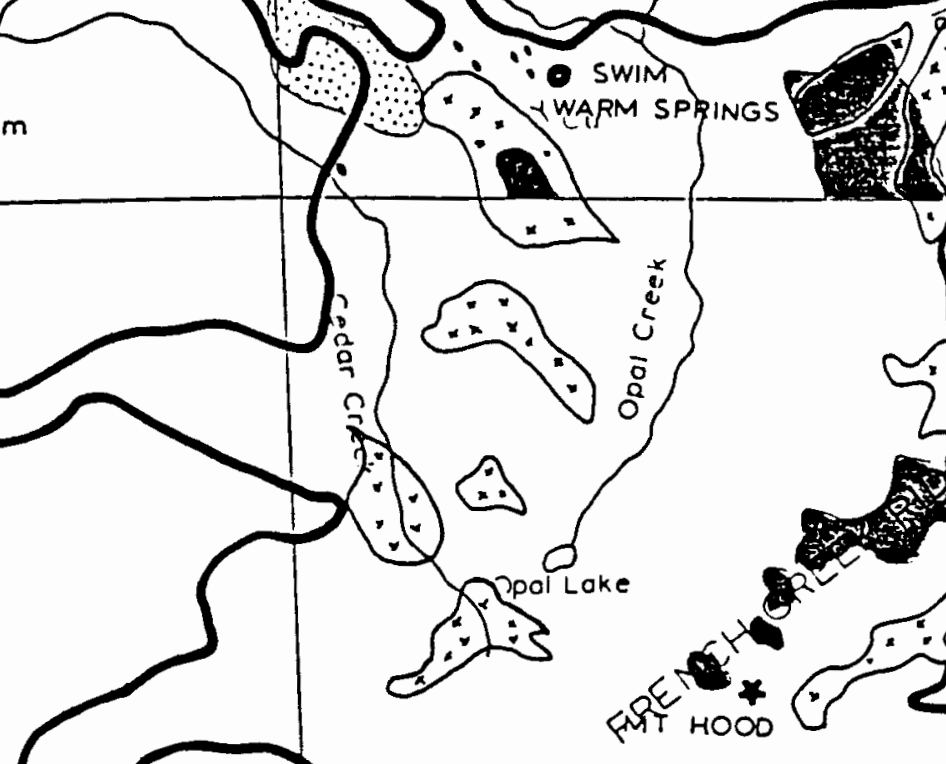

\section{ke}
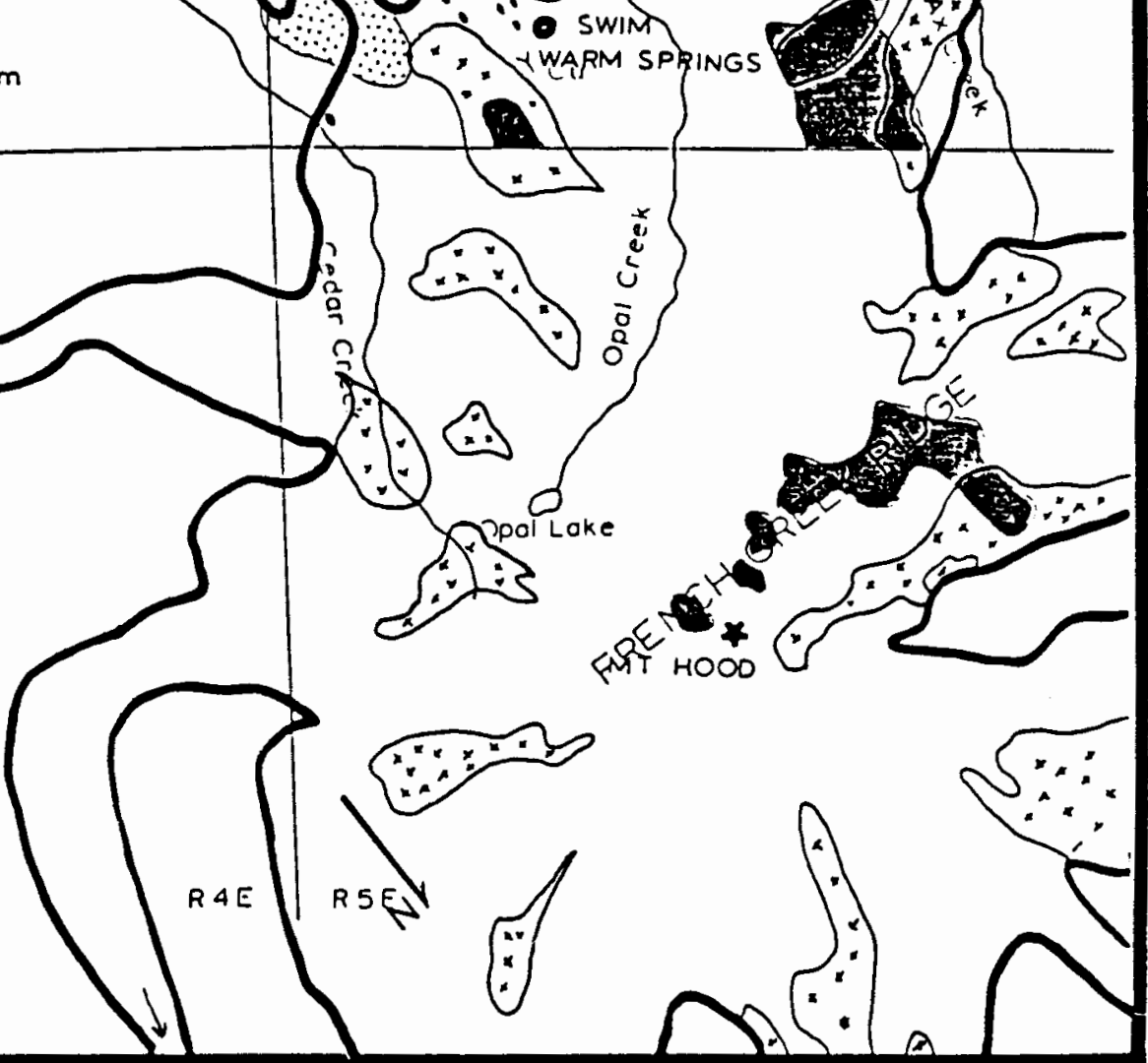

Figure 34. Model for the paleosurface at the time of mineralization. Dark line outlines Holocene deposits of Mt. Hood overlain on a map of the North Santiam mining area. 


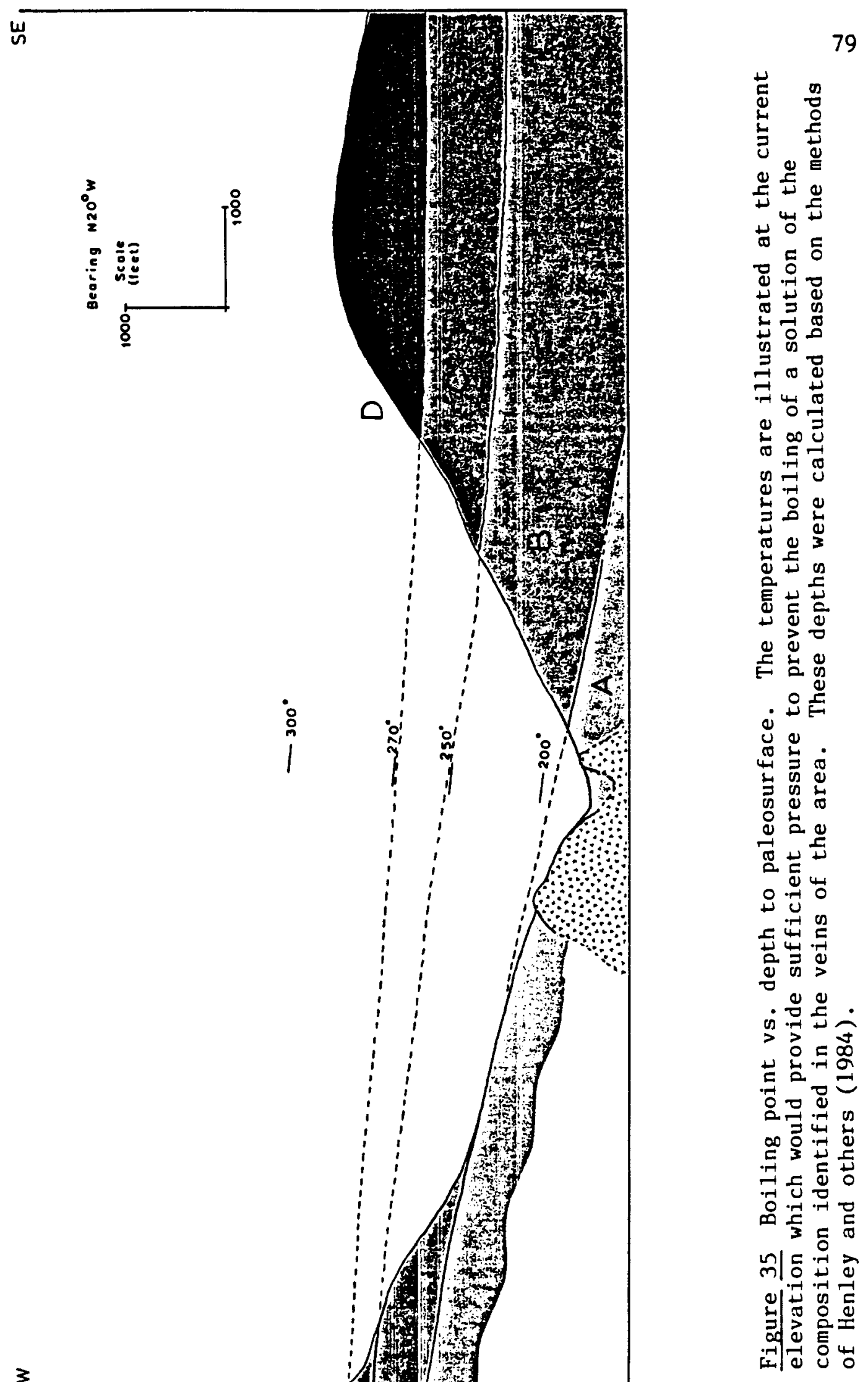




\section{CHAPTER VII}

\section{SUMMARY AND CONCLUSIONS}

Mineralization in the eastern portion of the North Santiam mining area consists of base-metal vein deposits similar to those found near the margins of porphyry-style copper deposits. Mineralization and the associated alteration in the area developed in response to the movement of geothermal fluids within and beneath a stratovolcano of a size similar to those in the modern Cascades. Due to uplift of the Western Cascade Range, more than a kilometer of that portion of the hydrothermal system between the magmatically dominated porphyry-style mineralization and the surface which existed at the time of mineralization are preserved and exposed.

The stratigraphy has been divided into four units which were assigned arbitrary letter designations beginning with the oldest (Unit A) through the youngest (Unit D). Unit A composed primarily of andesitic tuffs and Unit B composed primarily of flows served as hosts for the base-metal veins. Unit $C$, which is composed of andesitic to dacitic tuffs, and Unit $D$, which is composed of dark basaltic andesite to andesite flows, are postulated to have been erupted, at least in part, from a volcanic center on or near French Creek Ridge contemporaneous with mineralization.

Equigranular and porphyritic diorite intrusions crop out as 
northwest-trending dikes. The last intrusions emplaced consisted of a set of quartz-feldspar porphyry sills and dikes. Emplacement of these felsic intrusions was not controlled strongly by structure. Although they have not been dated, these intrusions may have vented as part of the early stages of activity related to the volcanic center on French Creek Ridge.

Propylitic alteration is widespread in the area and is of two types. 1) Pervasive replacement of groundmass and phenocryst phases by chlorite, epidote, calcite and albite is intense low in the section and decreases with increasing stratigraphic postion. This alteration reflects isochemical recrystallization resulting from burial and elevated geothermal gradients during volcanic activity. It preceeded, at least in part, the base-metal veins. 2) Quartz-epidote veinlets low and chlorite-calcite veinlets high in the section were precipitated from descending, warming fluids in a geothermal system. These veins are best developed on fractures, within vesicles and along the margins of equigranular diorite intrusions.

Phyllic alteration developed in conjunction with the base-metal veins was produced by ascending, cooling solutions. It is well developed within open-space "crackle" breccias in the quartz-feldspar porphyry intrusions. Calcite depostion in veins terminated or followed main-stage mineralization. Argillic alteration, characterized by kaolinization of hanging-wall breccias and accompanied by the precipitation of fine grained gypsum is the last major alteration noted. It may have developed in response to changes in the groundwater hydrologic system late in or following volcanic activity. 
Base-metal veins were deposited from ascending hydrothermal fluids which took advantage of major zones of vertical permeability along northwest-trending faults, major fractures, and the margins of existing intrusions. This mineralization post-dates all intrusions in the area, however, its relationship to open-space "crackle" breccias in the Ruth Mine suggests that it may have followed rather closely the emplacement of these felsic intrusions.

Fluid inclusions in the base-metal veins exhibit low salinities suggestive of a meteoric origin for the fluids. Homogenization temperatures of $220-295^{\circ} \mathrm{C}$ require a depth of formation exceeding $900 \mathrm{~m}$. Fluid salinities, homogenization temperatures, and the geometric relationships of quartz-epidote veins to the base-metal veins suggest that descending fluids providing recharge to the system, as well as ascending fluids, utilized the vertical porosity provided by the margins of existing diorite intrusions. The major vertical zones provided by faults were utilized exclusively by ascending solutions. 


\section{REFERENCES CITED}

Arnorsson S., 1978, Applications of the silica geothermometer in low temperature hydrothermal areas in Iceland: Am. J. Sci., v. 275, 763-784.

Avramenko, W., 1981, Volcanism and structure in the vicinity of Echo Mountain, central Oregon Cascade Range: Eugene, OR, University of Oregon masters thesis, $156 \mathrm{p}$.

Brooks, H. C., and Ramp, L., 1968, Gold and silver in Oregon: Oregon Department of Geology and Mineral Industries Bulletin 61, 337 p.

Callaghan, E., and Buddington, A. F., 1938, Metalliferous mineral deposits of the Cascade Range in Oregon: U. S. Geological Survey Bulletin $893,141 \mathrm{p}$.

Cummings, M. L., and Pollock, J. M., 1984, Field guide to the Northern Cascade Range from Zigzag to Jawbone Flats, Oregon with overviews of Poop Creek, Sisi Butte, and Pinhead Buttes: Portland State University, $59 \mathrm{p}$.

Decker, D. J., and Jones, M. B., 1977, North Santiam porphyry copper prospect, Marion County, Oregon, Summary Report: unpublished report to Freeport Mining Company, 24 p.

Dodd, S. P., and Schmidt, E. A. 1982, Termination report, Shiny Rock Project (D-80-65B), Marion County, Oregon: unpublished report to Amoco Minerals Company, $70 \mathrm{p}$.

Dyhrman, R. F., 1976, Geology of the Bagby Hot Springs area, Clackamas and Marion Counties, Oregon: Corvallis, OR, Oregon State University masters thesis, $78 \mathrm{p}$.

Ekambaram, V., Kawabe, I., Tanaka, T., Davis, A. M., and Grossman, L., 1984, Chemical compositions of refractory inclusions in Murchison C2 chondrite: Geochim. Cosmochim. Acta, v.48, p. 2089-2105.

Flaherty, G. M., 1981, The Western Cascade-High Cascade transition in the McKenzie Bridge area, central Oregon Cascade Range: Eugene, OR, University of Oregon masters thesis, $178 \mathrm{p}$.

George, A. J., 1985, The North Santiam mining district of the Oregon Cascades: A cultural inventory and historical survey: Lyons, OR, Shiny Rock Mining Corporation, 336 p. 
Giggenbach, W. F., 1984, Mass transfer in hydrothermal alteration systems--a conceptual approach: Geochim. Cosmochim. Acta, v. 48, p. 2693-2712.

Gray, J. J., 1977, A geological field trip guide from Sweet Home, Oregon, to the Quartzville Mining District: Oregon Department of Geology and Mineral Industries The Ore Bin, v. 39, no. 6, p. 93108.

Gray, J. J., 1978, Overview of the Bohemia Mining District: Oregon Department of Geology and Mineral Industries The Ore Bin, v. 40, no. 5, p. 77-91.

Gray, J. J., and Berri, D. A., 1983, Mineral potential of the Fall Creek mining district: a geological-geochemical survey: Oregon Department of Geology and Mineral Industries Open-File Report $0-83-5,32 \mathrm{p}$.

Gray, J. J., and Vogt, B. F., 1978, A geological field trip guide from Cottage Grove, Oregon to the Bohemia Mining District: Oregon Department of Geology and Mineral Industries The Ore Bin, v. 40, no. 6, p. 93-116.

Hales, P. 0., 1975, Geology of the Green Ridge area, Whitewater River quadrangle, Oregon: Corvallis, OR, Oregon State University masters thesis, $90 \mathrm{p}$.

Hammond, P. E., 1979, A tectonic model for evolution of the Cascade Range, in Armentrout, J. M. Cole, M. R., and Terbest, H., Jr., eds., Cenozoic paleogeography of the Western United States: Pacific Coast Paleogeography Symposium No. 3, Anaheim, CA, Society of Economic Paleontologists and Mineralogists, Pacific Section, p. 219-237.

Hammond, P. E., Anderson, J. L., and Manning, K. J., 1980, Guide to the geology of the upper Clackamas and North Santiam Rivers area, northern Oregon Cascade Range, in Oles, K. F., Johnson, J. G., Niem, A. R., and Niem, W. A., eds., Geologic field trips in western Oregon and southwestern Washington: Oregon Department of Geology and Mineral Industries Bulletin 101, p. 133-167.

Hammond, P. E., Manning-Geyer, K., and Anderson, J. L., 1982, Preliminary geologic map and cross sections of the upper Clackamas and North Santiam Rivers area, Northern Oregon Cascade Range: Available from Department of Geology, Portland State University, P. 0. Box 751, Portland, Oregon 97207.

Henley, R. W., and Ellis, A. J., 1983, Geothermal systems ancient and modern: a geochemical review: Earth Science Reviews, v. 19, p. $1-50$. 
Henley, R.W., Truesdell, A. H., and Barton, P. B., 1984, Fluid-mineral equilibria in hydrothermal systems: Reviews in Economic Geology, v. 1,267 p.

Istas, L. S., 1982, Trace elements in veins of the Bohemia Mining District, Oregon: Seattle, WA, University of Washington doctoral dissertation, $127 \mathrm{p}$.

Lutton, R. J., 1962, Geology of the Bohemia Mining District, Lane County, Oregon: Tucson, AZ, University of Arizona doctoral dissertation, $171 \mathrm{p}$.

Mason, R. S., Gray, J. J., and Vogt, B. F., 1977, Mineralization in the north-central Western Cascades: Oregon Department of Geology and Mineral Industries The Ore Bin, v. 39, no. 12, p. 185-205.

Munts, S. R., 1978, Geology and mineral deposits of the Quartzville mining district, Linn County, Oregon: Eugene, OR, University of Oregon masters thesis, $213 \mathrm{p}$.

01son, J. P., 1978, Geology and mineralization of the North Santiam Mining District, Marion County, Oregon: Corvallis, OR, Oregon State University masters thesis, $135 \mathrm{p}$.

Oregon Department of Geology and Mineral Industries, 1951, Oregon metal mines handbook: Oregon Department of Geology and Mineral Industries Bulletin No. 14-D, $166 \mathrm{p}$.

Peck, D. L., Griggs, A. B., Schlicker, H. G., Wells, F. G., and Dole, H. M., 1964, Geology of the central and northern parts of the Western Cascade Range in Oregon: U. S. Geological Survey Professional Paper 449, $56 \mathrm{p}$.

Power, S. G., Field, C. W., Armstrong, R. L., and Harakal, J. E., $1981 \mathrm{a}, \mathrm{K}-\mathrm{Ar}$ ages of plutonism and mineralization, Western Cascades, Oregon and Southern Washington: Isochron/West, no. 31, p. $27-29$.

Power, S. G., Field, C. W., Armstrong, R. L., and Harakal, J. E., $1981 \mathrm{~b}, \mathrm{~K}-\mathrm{Ar}$ ages of plutonism and mineralization, Western Cascades, Oregon and Southern Washington, Additional information: Isochron/West, no. 32 , p. 3.

Priest, G. R., Woller, N. M., Black, G. L., and Evans, S. H., 1983, Overview of the geology of the central Oregon Cascade Range, in Priest, G. R., and Vogt, B. F., eds., Geology and Geothermal Resources of the central Oregon Cascade Range: Oregon Department of Geology and Mineral Industries Special Paper 15, p. 3-28.

Roedder, E., 1984, Fluid Inclusions: Reviews in Mineralogy, v. 12., $644 \mathrm{p}$. 
Sillitoe, R. H., 1973, The tops and bottoms of porphyry copper deposits: Econ. Geol., v. 68, p. 799-815.

Storch, S. G. P., 1978, Geology of the Blue River mining district, Linn and Lane Counties, Oregon: Corvallis, OR, Oregon State University masters thesis, $70 \mathrm{p}$.

Taylor, E. M., 1980, Volcanic and volcaniclastic rocks on the east flank of the central Cascade Range to the Deschutes River, Oregon, in Oles, K. F., Johnson, J. G., Niem, A. R., and Niem, W. A., eds., Geologic field trips in western Oregon and southwestern Washington: Oregon Department of Geology and Mineral Industries Bulletin 101, p. 1-7.

Taylor, H. P., Jr., 1971, Oxygen isotope evidence for large-scale interaction between meteoric ground waters and Tertiary granodiorite intrusions, Western Cascade Range, Oregon: Journal of Geophysical Research, v. 76, no. 32, p. 7855-7874.

Thayer, T. P., 1936, Structure of the North Santiam River section of the Cascade Mountains in Oregon: Journal of Geology, v. 44, no. 6, p. 701-716.

Thayer, T. P., 1939, Geology of the Salem Hills and the North Santiam River Basin Oregon: Oregon Department of Geology and Mineral Industries Bulletin No. $15,40 \mathrm{p}$.

Turner, F. J., 1981, Metamorphic petrology: Mineralogical, field, and tectonic aspects, 2nd. ed.: New York, McGraw-Hill, 524 p.

Wells, F. G., and Peck, D. L., 1961, Geologic map of Oregon west of the 121 st meridian: U.S. Geological Survey Miscellaneous Investigations Series Map I-315, scale 1:500,000.

White, C., 1980a, Geology of the Breitenbush Hot Springs quadrangle, Oregon: Oregon Department of Geology and Mineral Industries Special Paper 9, 26 pp.

White, C., 1980b, Geology and geochemistry of volcanic rocks in the Detroit area, Western Cascade Range, Oregon: Eugene, OR, University of Oregon doctoral dissertation, $178 \mathrm{p}$.

White, C. M., and McBirney, A. R., 1979, Some quantitative aspects of orogenic volcanism in the Oregon Cascades, in Smith, R. B., and Eaton, G. P., eds., Cenozoic tectonics and regional geophysics of the Western Cordillera: Geological Society of America Memoir 152, p. 369-388. 


\section{APPENDIX A \\ MEASURED SECTIONS AND TRAVERSES}

Measured sections on the next page were used for defining the stratigraphy and were generated during the traverses described below. Locations for these samples appear in Appendix B and are shown on Plate I. Unit designations are those discussed in Chapter III of the text. Elevations appearing in this appendix and in the text were determined with a pocket altimeter which was set in Jawbone Flats (elev. $2100 \mathrm{ft}$ ) before each traverse and checked at the end. Adjustments were made for changes in the barometric pressure. The accuracy of reported elevations is about $+/-100 \mathrm{ft}$.

Traverse designations represented by the first portion of each sample number are as follow:

MR-35 Main road, Sect. 35, beginning at south section boundary

B-35 South boundary, Sect. 35, beginning at main road

A-35 Unnamed drainage, north half, Sect 35

RD-27 Henness $\mathrm{Cr}$. (Ruth drainage), Sect. 27

W-28 McCarver Cr. drainage, Sect. $27 \& 28$

ML-28 Road past new mill, Sect. 28, beginning at Jawbone Flats

OC-28 Opal Cr., Sect. 28, beginning at Jawbone Flats

OC-33 Opal Cr., Sect. 33, beginning at north section boundary

B-33 Ridge south of Flume Ck. (Opal Cr. tributary), Sect. 33

A-28 West boundary, Sect. 28; Jawbone Flats towards Whetstone

WM- Whetstone Mtn trail, Battle Ax Creek (Sect. 26) to top (Sect. 21) 


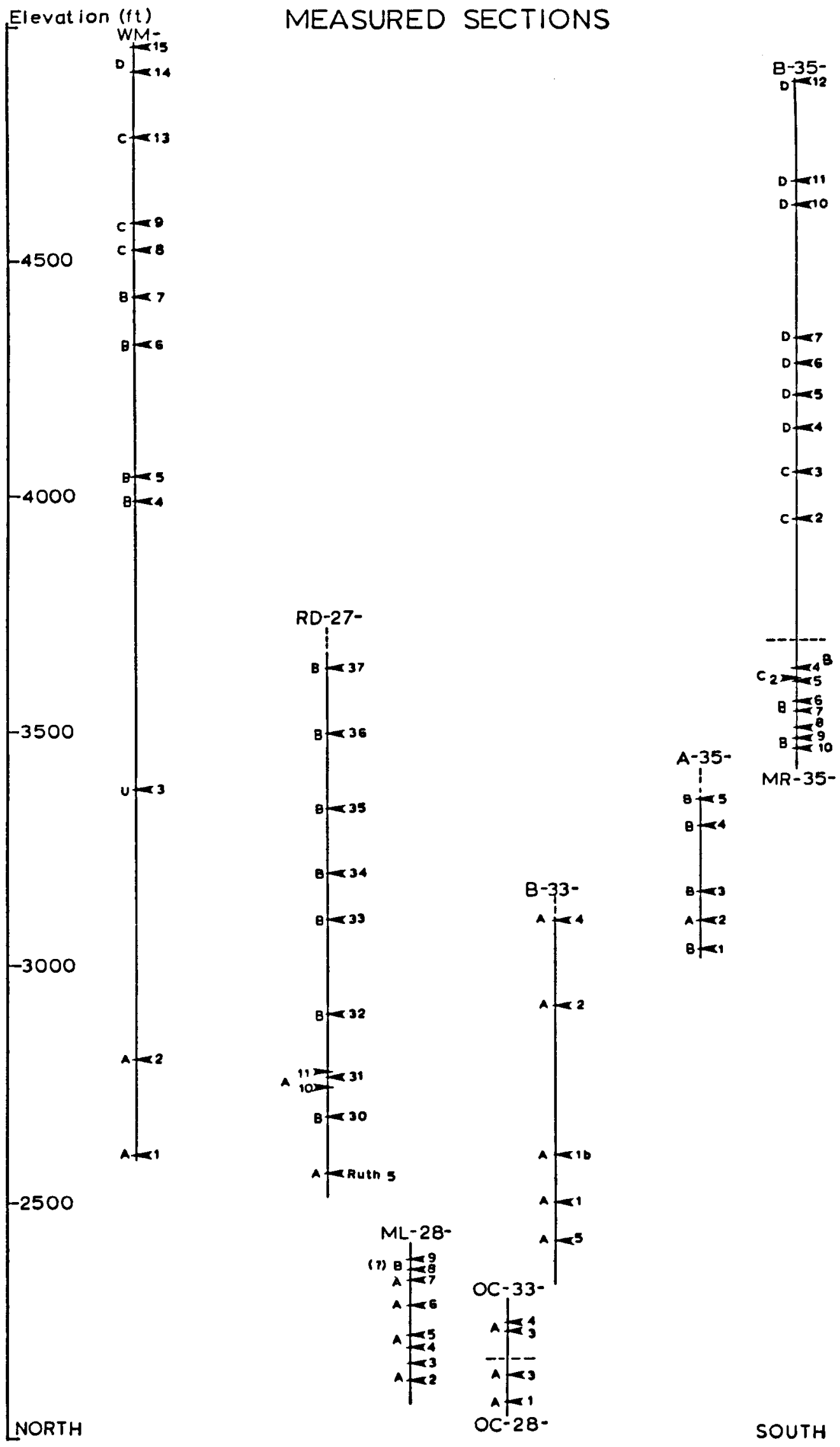




\section{APPENDIX B}

LOCATIONS AND DESCRIPTIONS OF ANALYZED AND DESCRIBED SAMPLES

Sample $1 / 41 / 41 / 4$ SECT. ELEV. DESCRIPTION AND COMENTS (see footnotes)

(*) (ft)

\section{SAMPLES USED FOR DEFINING STRATIGRAPHY}

$\begin{array}{llllll}\text { MR-35-1 } & \text { SW } & \text { SW } & \text { SE } & 35 & \text { XXXX } \\ \text { MR-35-2 } & \text { SW } & \text { SW } & \text { SE } & 35 & 3620 \\ \text { MR-35-3 } & \text { SW } & \text { SW } & \text { SE } & 35 & 3625 \\ \text { MR-35-4 } & \text { SW } & \text { SW } & \text { SE } & 35 & 3620 \\ \text { MR-35-5 } & \text { NW } & \text { SW } & \text { SE } & 35 & 3640 \\ \text { MR-35-6 } & \text { NW } & \text { SW } & \text { SE } & 35 & 3570 \\ \text { MR-35-7 } & \text { SW } & \text { NW } & \text { SE } & 35 & 3560\end{array}$

$\begin{array}{llllll}\text { MR-35-8 NE } & \text { SW } & \text { SE } & 35 & 3505\end{array}$

MR-35-9 NE SW SE $35 \quad 3490$

MR-35-10 NE SW SE $35 \quad 3480$

B-35-1 SW SW SE $35 \quad 3820$

B-35-2 SE SE SW $35 \quad 3970$

B-35-3 SE SE SW $35 \quad 4030$

B-35-4 SE SE SW $35 \quad 4140$

B-35-5 NW NE NH $2 \quad 4210$

B-35-6 NW NE NW *2 4280

B-35-7 NH NE NH 24320

B-35-8 NW NE NW $* 2 \quad 4330$

B-35-9 NE NW NW *2 4520

B-35-10 NW NW NW *2 4620

B-35-11 NW NW NW *2 4680

B-35-12 *2, *3,34,35 4885

A-34-1 SE SE SE $34 \quad 4860$

A-34-2 SE SE SE $34 \quad 4800$

A-35-1 SH NH NE $35 \quad 3040$

A-35-2 SW NW NE $35 \quad 3100$

A-35-3 SW NW NE $35 \quad 3160$

A-35-4 SW NW NE $35 \quad 3300$
Sample number reserved for float along road in section 35

Hornblende andesite flow; hornblende, unaltered, to 1 cm; plagioclase, augite, minor alteration of chlorite after mafics (1)

Highly friable material; appears to be deep baked zone in flow top

Oxidized porphyritic andesite flowtop, red platy fracture

Porphyritic andesite flow; red, platy fracture surfaces (2)

Porphyritic andesite flow; red groundmass with disseminated hematite

Porphyritic andesite flow; hematite staining on fracture surfaces and dissemineted hematite throughout; Plagloclase glomeocrysts to 6 m; minor alteration $(1,2)$

Porphyritic andesite flow; feldspar phenocrysts and glomerocrysts; medium gray, lacks distinct red hematite (2)

Porphyritic andesite flow: (2)

Porphyritic andesite flowtop breccia; nearly dictytaxitic, no red hematite fracture surfaces, ortentation of plagioclase microlites $(1,2)$

(float)

Crysta1-1ithic tuff; xstls: plagioclase (35\%), augite; orthopyroxene (?), relict hornblende; Alteration: plag to cley, opx to chlorite/clay. $(1,2)$

Mudflow or tuff breccia, clasts to $10 \mathrm{~cm}$., matrix supported

Porphyritic basaltic andesite flow; Dk. brown-black

Porphyritic besaltic andesite flow; Dk. brown-black (2)

Porphyritic basaltic andesite flow: Dk. brown-black; plag. An=60, augite, opx (?) altered to uralite $+/$ - silica, unidentified zeolite veinlet $(1,2)$

Porphyritic basaltic andesite flow; Dk. brown-black (2)

Crystal vitric tuff; similiar to B-35-9 but lacks calcedony: samples B35-8 and -9 were collected south of a fault which trends $N$. $80^{\circ} \mathrm{E}$. (2)

Crystal-vitric tuff; light yellow-brown; plag. to 6 man, pyroxene, pumice to $10 \mathrm{~mm}$; Alteration: quartz (calcedony ?) after??, plag. to clay, px to chlorite, zeolite on fracture surface. (2)

Porphyritic basaltic andesite flow; Dk. brown

Porphyritic basaltic andesite flow: DK. brown

Porphyritic basaltic andesite; Dk. brown; collected at USGS surveyed corner marker.

Porphyritic basaltic andesite flow; Dk. brown

Porphyritic basaltic andesite flow: Dk, brown

Porphyritic andesite flow; red platy fracture surfaces; underlying paleosol or otream sediment deeply baked. (2)

Crystal lithic tuff; plag (25\%) to $5 \mathrm{~mm}$, glomeroporphyritic; extensive Alteration: mafics to chlorite; plag. to calcite, clay, and silica; silicification of groundmass; clast boundaries defined by changes in groundmass opaques (1)

Porphyritic andesite flow; red platy fracture surfaces; plas. phenocrysts and glomerocrysts. (2)

Porphyritic andesite flow (?): Same rock as A-35-5, zeolite veining. 


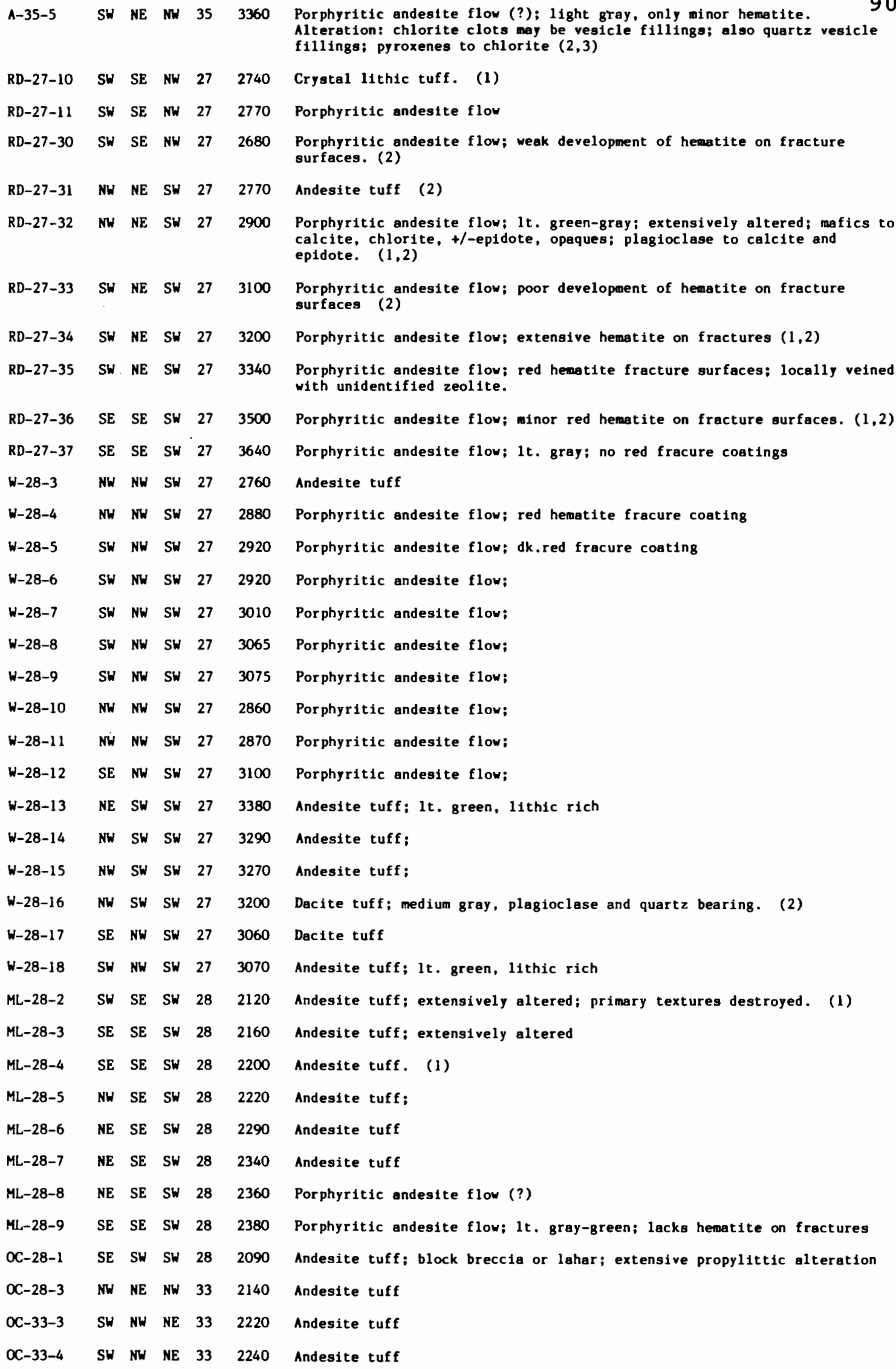

RD-27-10 SW SE NW $27 \quad 2740$

RD-27-11 SW $\quad$ SE $\quad$ NW $\quad 27 \quad 2770$

RD-27-30 SW SE NW $27 \quad 2680$

RD-27-31 NW NE $\quad$ SW $27 \quad 2770$

RD-27-32 NW NE $\quad$ SW $27 \quad 2900$

RD-27-33 SW NE $\quad$ SW $\quad 27 \quad 3100$

RD-27-34 SW NE SW $27 \quad 3200$

RD-27-35 SW. NE SW $27 \quad 3340$

RD-27-36 SE $\quad$ SE $\quad$ SW $27 \quad 3500$

$\begin{array}{llllll}\text { RD-27-37 } & \text { SE } & \text { SE } & \text { SW } & 27 & 3640\end{array}$

W-28-3 NW NW SW $27 \quad 2760$

$\begin{array}{llllll}W-28-4 & \text { NW } & \text { NW } & \text { SW } & 27 & 2880\end{array}$

$\begin{array}{llllll}W-28-5 & \text { SW NW } & \text { SW } & 27 & 2920\end{array}$

W-28-6 SW NW SW $27 \quad 2920$

W-28-7 SW NW SW $27 \quad 3010$

$\begin{array}{llllll}W-28-8 & \text { SW } & \text { NW } & \text { SW } & 27 & 3065\end{array}$

$\begin{array}{llllll}W-28-9 & \text { SW NW } & \text { SW } & 27 & 3075\end{array}$

W-28-10 NW NW SW $27 \quad 2860$

W-28-11 NW NW SW $27 \quad 2870$

W-28-12 SE NW $\quad$ SW $27 \quad 3100$

W-28-13 NE SW SW $27 \quad 3380$

W-28-14 NW SW SW $27 \quad 3290$

W-28-15 NW SW SW $27 \quad 3270$

$\begin{array}{llllll}\text { W-28-16 } & \text { NW } & \text { SW } & \text { SW } & 27 & 3200\end{array}$

W-28-17 SE NW SW $27 \quad 3060$

$\begin{array}{llllll}W-28-18 & \text { SW } & \text { NW } & \text { SW } & 27 & 3070\end{array}$

$\begin{array}{llllll}M L-28-2 & \text { SW } & \text { SE } & \text { SW } & 28 & 2120\end{array}$

ML-28-3 SE $\quad$ SE $\quad$ SW $28 \quad 2160$

$\begin{array}{llllll}M L-28-4 & \text { SE } & \text { SE } & \text { SW } & 28 & 2200\end{array}$

ML-28-5 NW SE $\quad$ SW $28 \quad 2220$

ML-28-6 NE SE SW $28 \quad 2290$

ML-28-7 NE $\quad$ SE $\quad$ SW $28 \quad 2340$

$\begin{array}{llllll}M L-28-8 & \text { NE } & \text { SE } & \text { SW } & 28 & 2360\end{array}$

$\begin{array}{llllll}M L-28-9 & \text { SE } & \text { SE } & \text { SW } & 28 & 2380\end{array}$

$\begin{array}{llllll}\text { OC-28-1 } & \text { SE } & \text { SW } & \text { SW } & 28 & 2090\end{array}$

OC-28-3 NW HE NW $33 \quad 2140$

OC-33-3 SW NW NE $33 \quad 2220$

OC-33-4 SW NW NE $33 \quad 2240$

Crystal lithic tuff. (1)

Porphyritic andesite flow

Porphyritic andesite flow; weak development of hematite on fracture surfaces. (2)

Andesite tuff (2)

Porphyritic andesite flow: 1t. green-gray: extensively altered; mafics to calcite, chlorite, +/-epidote, opaques; plagioclase to calcite and epidote. $(1,2)$

Porphyritic andesite flow; poor development of hematite on fracture surfaces (2)

Porphyritic andesite flow; extensive hematite on fractures $(1,2)$

Porphyritic andesite flow; red hematite fracture surfaces; locally veined with unidentified zeolite.

Porphyritic andesite flow; minor red hematite on fracture surfaces. $(1,2)$

Porphyritic andesite flow; 1 t. gray; no red fracure coatings

Andesite tuff

Porphyritic andesite flow; red hematite fracure coating

Porphyritic andesite flow; dk,red fracure coating

Porphyritic andesite flow;

Porphyritic andesite flow:

Porphyritic andesite flow;

Porphyritic andesite flow;

Porphyritic andestte flow;

Porphyritic andesite flow;

Porphyritic andesite flow;

Andesite tuff; 1 t. green, 1ithic rich

Andesite tuff;

Andesite tuff;

Dacite tuff; medium gray, plagioclase and quartz bearing. (2)

Dacite tuff

Andesite tuff; 1 t. green, lithic rich

Andesite tuff; extensively altered; primary textures destroyed. (1)

Andesite tuff; extensively altered

Andesite tuff. (1)

Andesite tuf $;$

Andesite tuff

Andesite tuff

Porphyritic andesite flow (?)

Porphyritic andesite flow; 1t. gray-green; lacks hematite on fractures

Andesite tuff; block breccia or lahar; extensive propylittic alteration

Andesite tuff

Andesite tuff

Andesite tuf $f$ 


\begin{tabular}{|c|c|c|c|c|c|c|}
\hline B-33-1 & SW & NW & NE & 33 & 2500 & Andesite tuff \\
\hline B-33-2 & NW & SE & NE & 33 & 2920 & Andesite tuff \\
\hline B-33-3 & NW & SE & NE & 33 & 3040 & Andesite tuff \\
\hline B-33-4 & SE & SE & NE & 33 & 3260 & Andesite tuff \\
\hline B-33-5 & NE & SW & NE & 33 & 2420 & Andesite tuff \\
\hline WM-1 & NW & NW & NW & 26 & 2600 & $\begin{array}{l}\text { Andesitic crystal lithic tuff; pumice stretched to } 3 \mathrm{~cm} \text {; lathe shaped } \\
\text { plagioclase crystals to } 2 \mathrm{~mm} \text { in matrix and clasts. }\end{array}$ \\
\hline$W M-2$ & NW & NW & NW & 26 & 2800 & $\begin{array}{l}\text { Andesitfc crystal lithic tuff breccia; same clast types as block brecci } \\
\text { in Battle Ax Creek includes plagioclase crystals in matrix; }\end{array}$ \\
\hline$W M-3$ & NW & SW & SE & 22 & 3380 & $\begin{array}{l}\text { Dacite crystal tuff; plagioclase, quartz, hornblende, blotite (?), } \\
\text { crystals; extensive replacement by silica and calcite. }(1,2)\end{array}$ \\
\hline WM-4 & NW & NE & SW & 22 & 3990 & $\begin{array}{l}\text { Porphyritic andesite flow; red, platy jointing; glomerophyric } \\
\text { plagloclase; clinopyroxene; ( } 2)\end{array}$ \\
\hline$W M-5$ & NW & NW & SW & 22 & 4040 & Porphyritic andesite flow; hematite on fracture surfaces. \\
\hline WM-6 & NW & NW & SE & 22 & 4320 & Porphyritic andesite flow; $(1,2)$ \\
\hline WM-7 & NW & NW & SE & 22 & 4420 & Porphyritic andesite flow; Red hematite fracture coatings. (2) \\
\hline WM-8 & NE & NE & SW & 22 & 4540 & Andesite lithic tuff; $1 \mathrm{t}$. gray; clasts to $3 \mathrm{~mm}$; rare stretched punice \\
\hline WM-9 & NW & NE & SW & 22 & 4580 & $\begin{array}{l}\text { Dacite tuff; lt. pink, rare mafic phases, quartz, feldspar, pumice; } \\
\text { grades upward into fine grained, gray, bedded tuff and continues into } \\
\text { very fine grained brown, quartz bearing, laminated deposit which contai } \\
\text { orfented carbonized plant material. ( } 1 \text {, laminated deposit) }\end{array}$ \\
\hline WM-13 & SE & NW & SW & 22 & 4760 & Andesite tuff \\
\hline WM-14 & NE & NW & SW & 21 & 4800 & $\begin{array}{l}\text { Porphyritic basaltic andesite flow; dk. brown-black; calcite-chlorite } \\
\text { veinlets. }(1,2)\end{array}$ \\
\hline WM-15 & $\mathrm{NE}$ & NW & SW & 21 & 4940 & Porphyritic basaltic andesite flow; top of Whetstone Mtn. \\
\hline
\end{tabular}

QUARTZ-FELDSPAR PORPHYRY INTRUSIONS

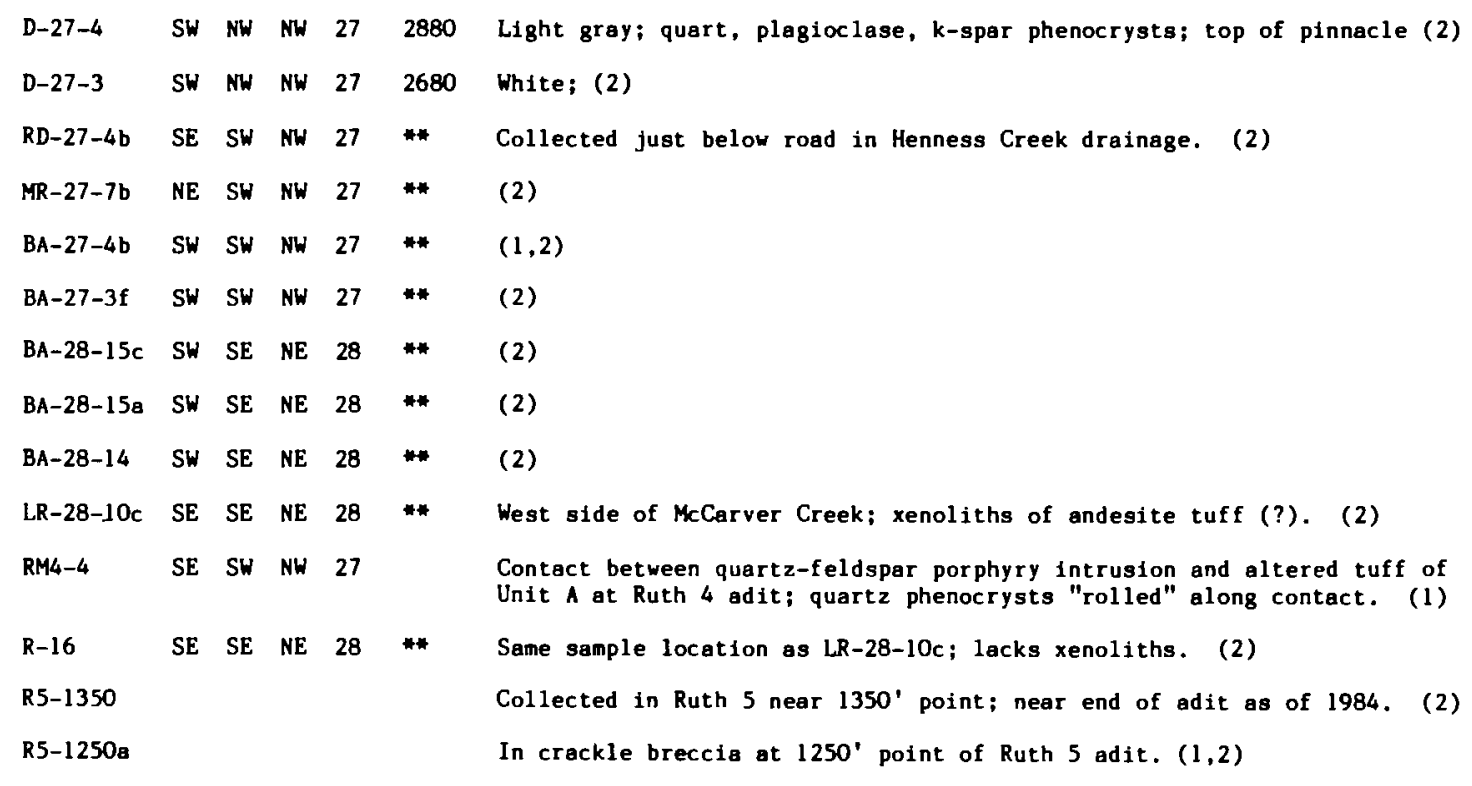

PORPHYRITIC DIORITE INTRUSIONS

$\begin{array}{lllllll}\text { BA-27-28 } & \text { SW } & \text { SW } & \text { NW } & 27 & * & (1,2) \\ \text { BA-27-3i } & \text { SW } & \text { SW } & \text { NW } & 27 & * & (1,2) \\ \text { BA-27-18 } & \text { SW } & \text { SW } & \text { NW } & 27 & * & (2) \\ \text { LR-27-48 } & \text { SW } & \text { SW } & \text { NW } & 27 & * & \end{array}$




$\begin{array}{llllll}\text { LR-27-41 } & \text { SW } & \text { SW } & \text { NW } & 27 & \\ \text { A-28-51 } & \text { NW } & \text { NW } & \text { SW } & 28 & 2460 \\ \text { MS-road } & \text { NW } & \text { SW } & \text { NE } & 27 & \\ \text { CC-2 } & \text { SW } & \text { SE } & \text { SE } & 32 & 3520\end{array}$

EQUIGRANULAR DIORITE INTRUSIONS

$\begin{array}{lllll}B A-27-12 c & \text { NE } & \text { SW } & \text { NW } & 27 \\ B A-27-11 b & \text { NE } & \text { SW } & \text { NW } & 27\end{array}$

BA-27-11 by NE SW NW 27 *

BA-27-11C NE SW NW 27 *

BA-27-1y SW SW NW 27 *

BA-28-23C SE SE NE 28 *

BA-28-23d SE SE NE 28 *

LR-27-1b SW SW NW 27 *

LR-28-11a SE SE NE 28 **

$A-28-51$ NW NW SW $28 \quad 2480$

$\begin{array}{lllll}A-28-5 m & N W & \text { NW } & 28 & 2440\end{array}$

ANDESITE DIKE

BA-28-6h NE NE SW 28

Rare resorbed quartz-phenocrysts

\section{ALTERED TUFFS}

$\begin{array}{lllll}B A-28-2 & \text { SW } & \text { NE } & \text { SW } & 28 \\ \text { BA-28-10 } & \text { NW } & \text { NW } & \text { SE } & 28\end{array}$

$\begin{array}{llllll}\text { SR-32-7 NE } & \text { SW } & \text { SW } & 33 & 3340\end{array}$

\section{VEINS AND VEIN CLAYS}

\section{R5-1050ST}

R5-1290

$B A-28-12 b$ NE NW SE 28 **

BA-27-21e SE NW NE 27 *

MR-28-6b NE NE SW 28 *

(2)

(2)

$(1,2)$

(2)

See Plate II and Figure 18. $(1,2,3)$

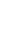

(2)

Sample collected along access road to the Morning Star Mine. (2)

Collected from location of dated intrusion (Power and others, 1981a) (2)

Sample from intrusion at confluence of Battle $A x$ and Henness Creeks; onalyzed sample avoided oplite vein; See $B A-27-11$ bv. $(1,2)$

Aplite vein separated from ane sample as BA-27-11b. $(1,2)$

"Freshest" equigranular diorite sample; Unaltered biotite. (1)

Road at McCarver Creek; quartz-epidote veining, epidote halos. $(1,2,4)$

Sequence of altered tuffa of Unit A; see Plate II. $(1,2)$ 


\section{APPENDIX C \\ INSTRUMENTAL NEUTRON ACTIVATION ANALYSIS DATA}

One gram samples were irradiated in the Reed College TRIGA Mark I research reactor at a nominal neutron flux of $2 \times 10^{12} \mathrm{n} / \mathrm{cm}^{2}-\mathrm{sec}$ for 1 hour. Analysis was conducted utilizing a Tracor Northern TN4000 gamma spectrometry system. Decay times of approximately 5 and 30 days allowed determination of up to 25 elements. Concentrations were determined by comparision to USGS Standard rock samples.

Data recorded in these table have the units of parts per million (ppm) except for $\mathrm{Na}, \mathrm{K}$, and $\mathrm{Fe}$ which are reported as a percentage of the oxide appearing in the heading. Error terms which follow each data item are in the same units and are based on one standard deviation (1 sigma) on the total count. Samples reported as non-detectable (N.D.) have calculated concentrations which do not exceed 3 times the counting error. Counting error and detection limit are dependent on half-life and for those elements with short half-lives (especially $K$ and $U$ ) the indication of a sample below detection limit may indicate that the sample was not counted as soon after irradiation as other samples and not that it necessarily contains less of the element.

Chondrite concentrations used for normalization are taken from Ekambaram and others (1984) and appear on page 100. 


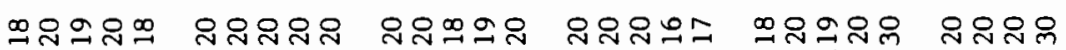

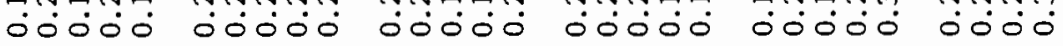

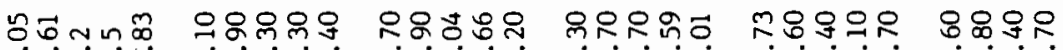

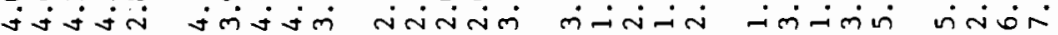

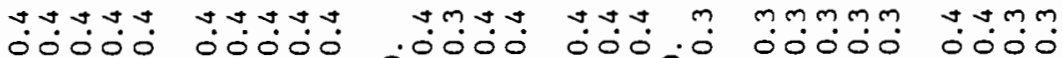

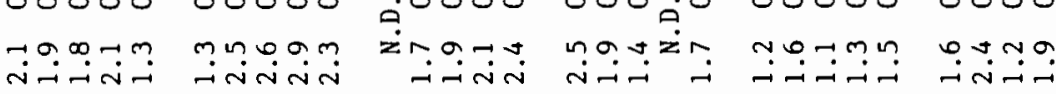

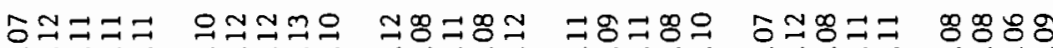

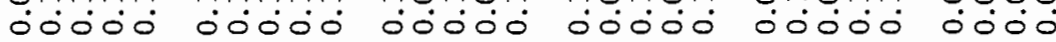

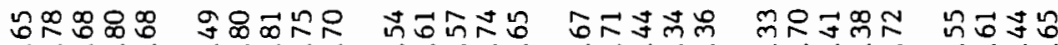

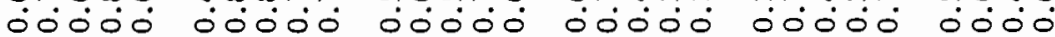

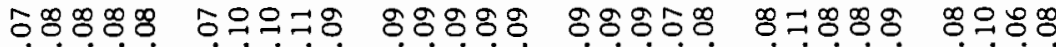

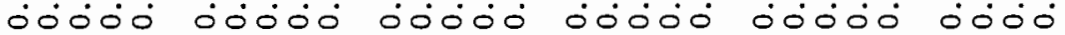

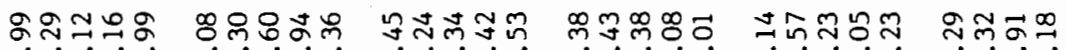

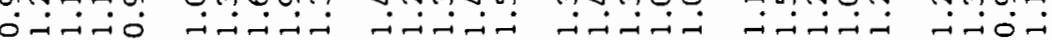

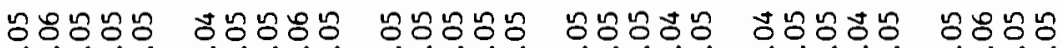

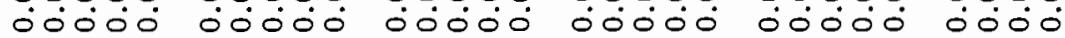

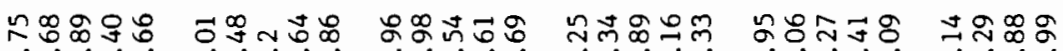

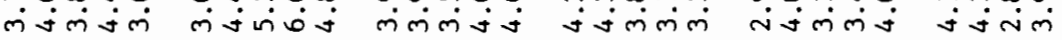

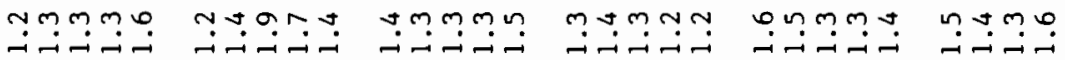

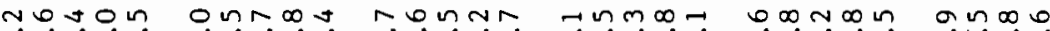

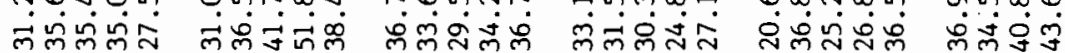

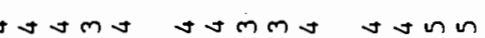

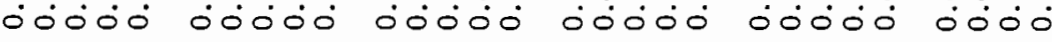
ganv? rovio notna ov-mo nvano amal

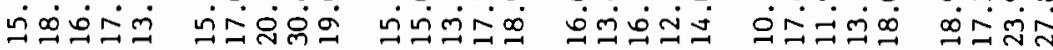




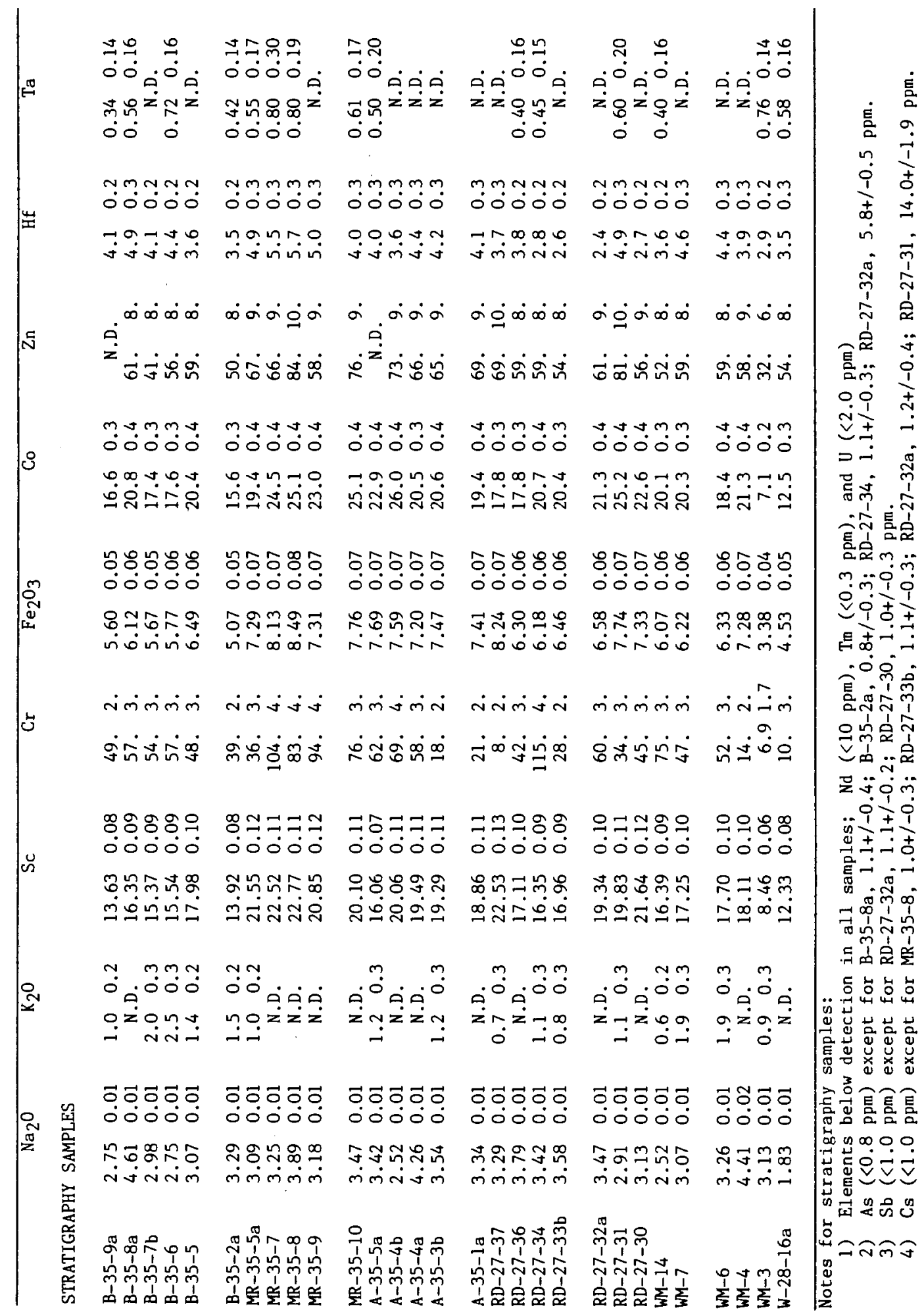




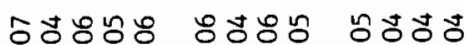
సักำ

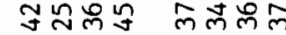
0000ல 0000 00ं0

tnoto nmino nutin

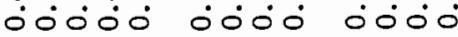

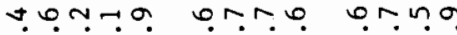

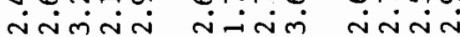

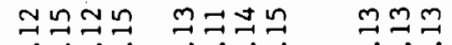
.0000 0000 .000

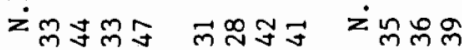
000 0ं00

ㅇํㅇํํ ㄴํㅇㅇํㅇํํ ல்0்க $\infty$ ก 00

Оं்-ं் ஸ்

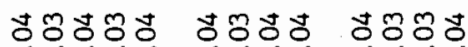
ஸ்0ல்

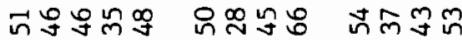

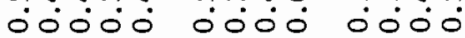

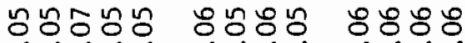
íoio 0000 0000

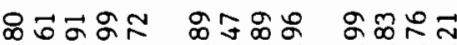

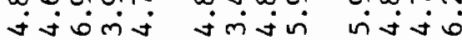

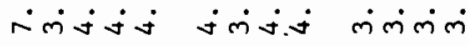

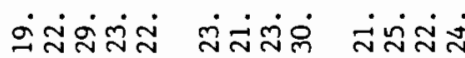

vonor rarm oodo

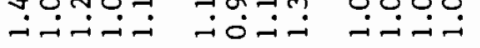

ต. $9 .-7$ n 000 n

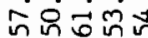
的守定

$\operatorname{lnvinvatavinnvat~}$ $0 \dot{000}$

m-ฺ.ฺ 0000 จิ่ $0 \rightarrow 0, \infty$ نेंลें

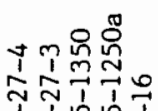
舟苦年出 ลกำล

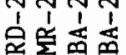

ณีळః

ஸं0்

$a \infty n \infty$ กิ่ง 0ं0்

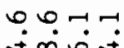
mं̊요 சீंற் த்

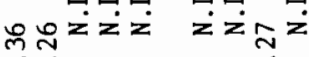
○ं $\dot{0}$

$\operatorname{tin} v+d$

t $\ln \frac{\sin }{0}$ ல்0ல் ல்0ல

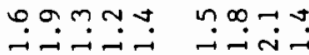

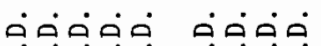
$\dot{z} z \dot{z} z \quad \dot{z} z \dot{z}$

ํํํํํํํำ ํํํํํำ ல0ं0்

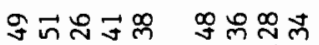
ல0்0ல

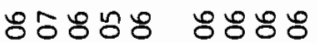
ஸ்0்0

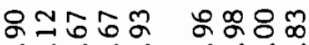
ல-í்

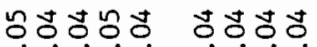

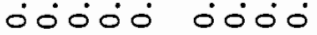

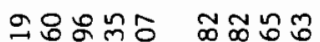
लिंतिल जivin

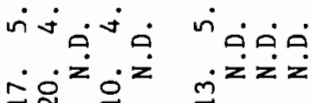
$90000 \quad 90000$

7noos avta लंল

ง.ง m.ง m. mก 00000 0000

TOONN m운.? ที่う் 은 ํำง $\begin{array}{llll}1 & 1 & 1 & 1 \\ 0 & 0 & \infty & 0 \\ 1 & 1 & 1 & 1\end{array}$

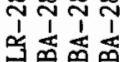

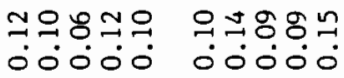
ํํ웜뀨 ०००00 ติํำ लี ○ं०்ं

o m v m m n m in un ர்0ं0 0000

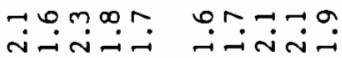

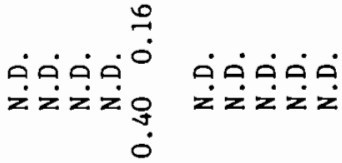

ํํํํํำ ํํํํํํํำ 0ं000 00000

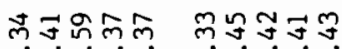
0000 00000

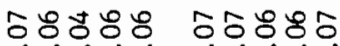

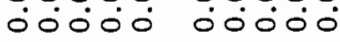

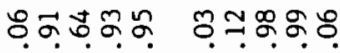

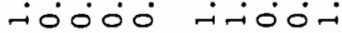

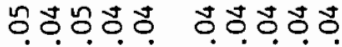
ல0ல0ல 00000

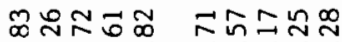

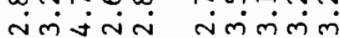

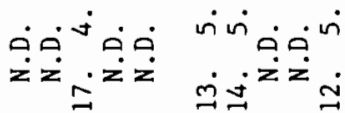

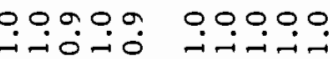

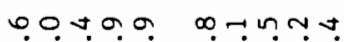

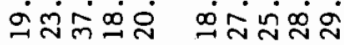

m. mm m.t. NNaOo munua ळं유

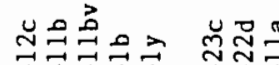
구구ำ

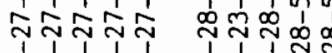

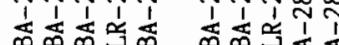




\begin{tabular}{|c|c|c|c|c|c|c|c|c|c|}
\hline \multirow[t]{2}{*}{ के } & \multirow{2}{*}{ 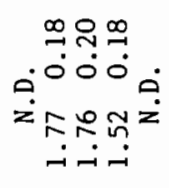 } & 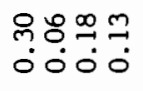 & \multirow{2}{*}{\multicolumn{2}{|c|}{ 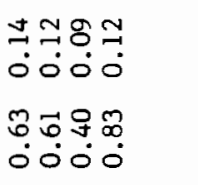 }} & 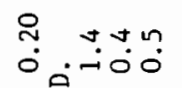 & \multirow{2}{*}{\multicolumn{2}{|c|}{ 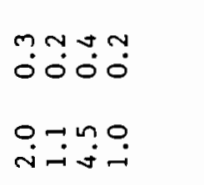 }} & \multirow{2}{*}{ 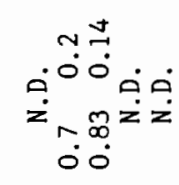 } & \multirow{2}{*}{ 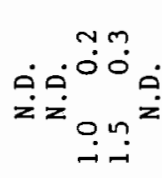 } \\
\hline & & 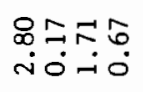 & & & 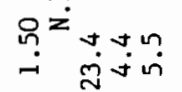 & & & & \\
\hline \multirow[t]{2}{*}{$\stackrel{n}{2}$} & $\dot{0} \dot{0} \dot{0} \dot{0}$ & $\stackrel{+}{\circ} \stackrel{+}{\circ} \dot{0} \cdot \dot{0}$ & $\ddot{0}+\ddot{0} \dot{0}$ & & 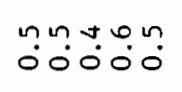 & 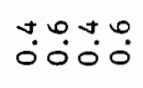 & & 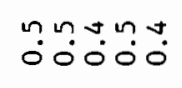 & نُ0 \\
\hline & : & $\dot{i} \hat{N}^{z} \dot{m}$ & 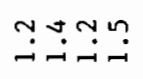 & & Mִ & 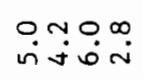 & & 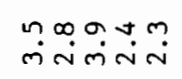 & 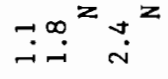 \\
\hline & $\because \stackrel{0}{\because}: 0$ & 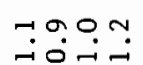 & ֻே: & & & & & $\rightarrow$ & \\
\hline & 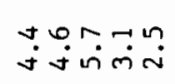 & $\ddot{g} \dot{\sigma} \dot{j} \dot{m}$ & 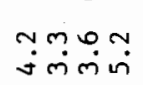 & & $\dot{z} \dot{z} \dot{z}$ & $\underset{i}{i} \dot{z}$ & & 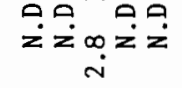 & 里是品品 \\
\hline \multirow{2}{*}{$E$} & 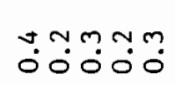 & 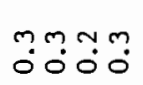 & ஸ்̃ & & 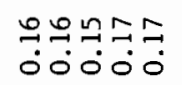 & 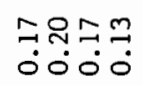 & & 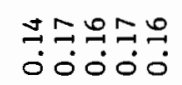 & 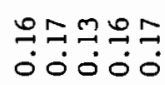 \\
\hline & نُ0்ْ & 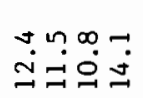 & 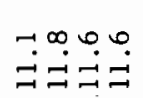 & & 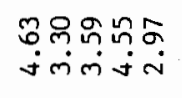 & $\begin{array}{l} \pm \& M \\
\text { miñ }\end{array}$ & & 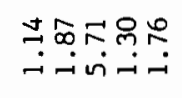 & 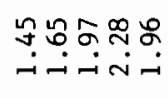 \\
\hline \multirow{2}{*}{$3^{\infty}$} & 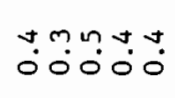 & 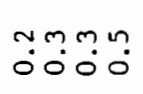 & 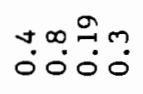 & & & ஸ் & & 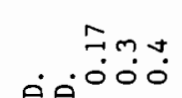 & $.0 \%$ \\
\hline & 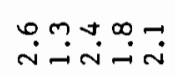 & 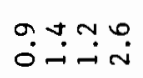 & $\vec{\sim} \dot{\sigma} \vec{\sigma}$ & & $\stackrel{\infty}{0}^{z} q \Omega^{z}$ & 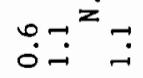 & & $\begin{array}{rl}z & =0 . \\
0 & 0 \\
0 & 0\end{array}$ & $\exists z^{z z}$ \\
\hline \multirow[t]{2}{*}{ 20 } & $\dot{\rho} \dot{0} \dot{0} \dot{\infty}$ & & & & $\dot{\sim} \cdot \dot{\infty} \dot{\infty} \dot{0}$ & $\dot{\Delta}^{\infty} \dot{\Omega^{\infty}}$ & & $\dot{\theta}^{\sim} \dot{\dot{\theta}}$ & \\
\hline & 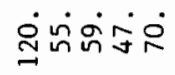 & $\dot{\sim} \dot{N} \dot{\infty} \underset{\sigma}{\sigma}$ & $\dot{\nabla} \dot{\infty} \dot{\Im} \dot{0} \dot{0}$ & & $\dot{n}^{z} \sin ^{z}$ & $\dot{z} \dot{\tilde{n}}$ & & 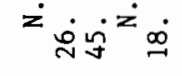 & \\
\hline \multirow{5}{*}{ 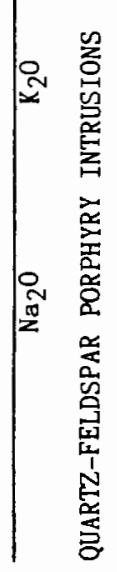 } & 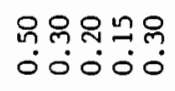 & 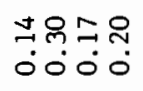 & 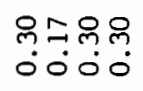 & \multirow{5}{*}{ 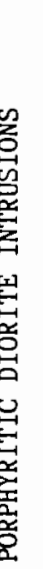 } & 유. 유. & $\stackrel{n}{\because} \cdot \stackrel{n}{0}$ & \multirow{5}{*}{ 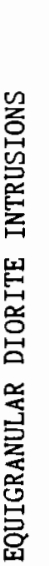 } & $\ddot{0} \ddot{0} \ddot{0} \dot{0}$ & ニmก: \\
\hline & 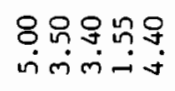 & 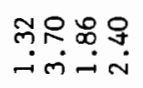 & 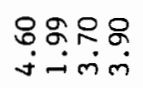 & & \begin{tabular}{c}
$8<8=$ \\
\hdashline \\
\hdashline
\end{tabular} & $\hat{\sigma}_{0}^{\dot{z}} \vec{i}$ & & 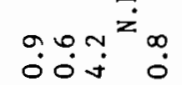 & 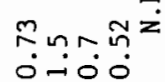 \\
\hline & $\begin{array}{l}\overrightarrow{0} \overrightarrow{0} \overrightarrow{0} 0 \overrightarrow{0} .0 \\
\dot{0} 0 \dot{0}\end{array}$ & 뭉ㅁ웅 & 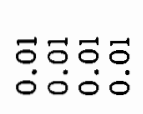 & & $\begin{array}{l}\overrightarrow{0} \sigma \overline{0} \overline{0} \\
\dot{0} \dot{0} \dot{0}\end{array}$ & 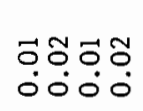 & & $\begin{array}{l}\overrightarrow{0} \overrightarrow{0} \overrightarrow{0} 0 \overrightarrow{0} \\
000 \\
0\end{array}$ & 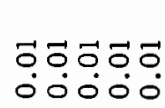 \\
\hline & 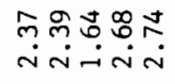 & 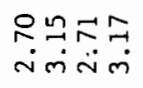 & 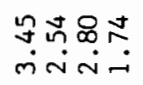 & & 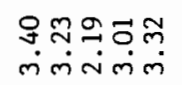 & 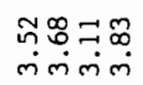 & & 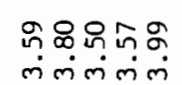 & 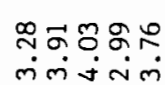 \\
\hline & 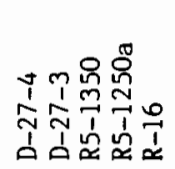 & 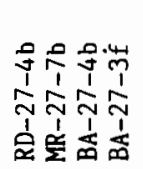 & 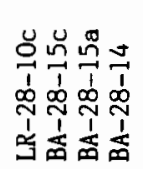 & & 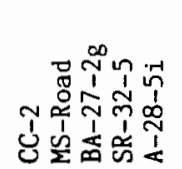 & 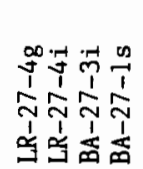 & & 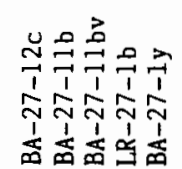 & 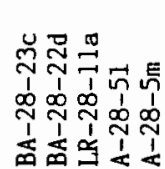 \\
\hline
\end{tabular}




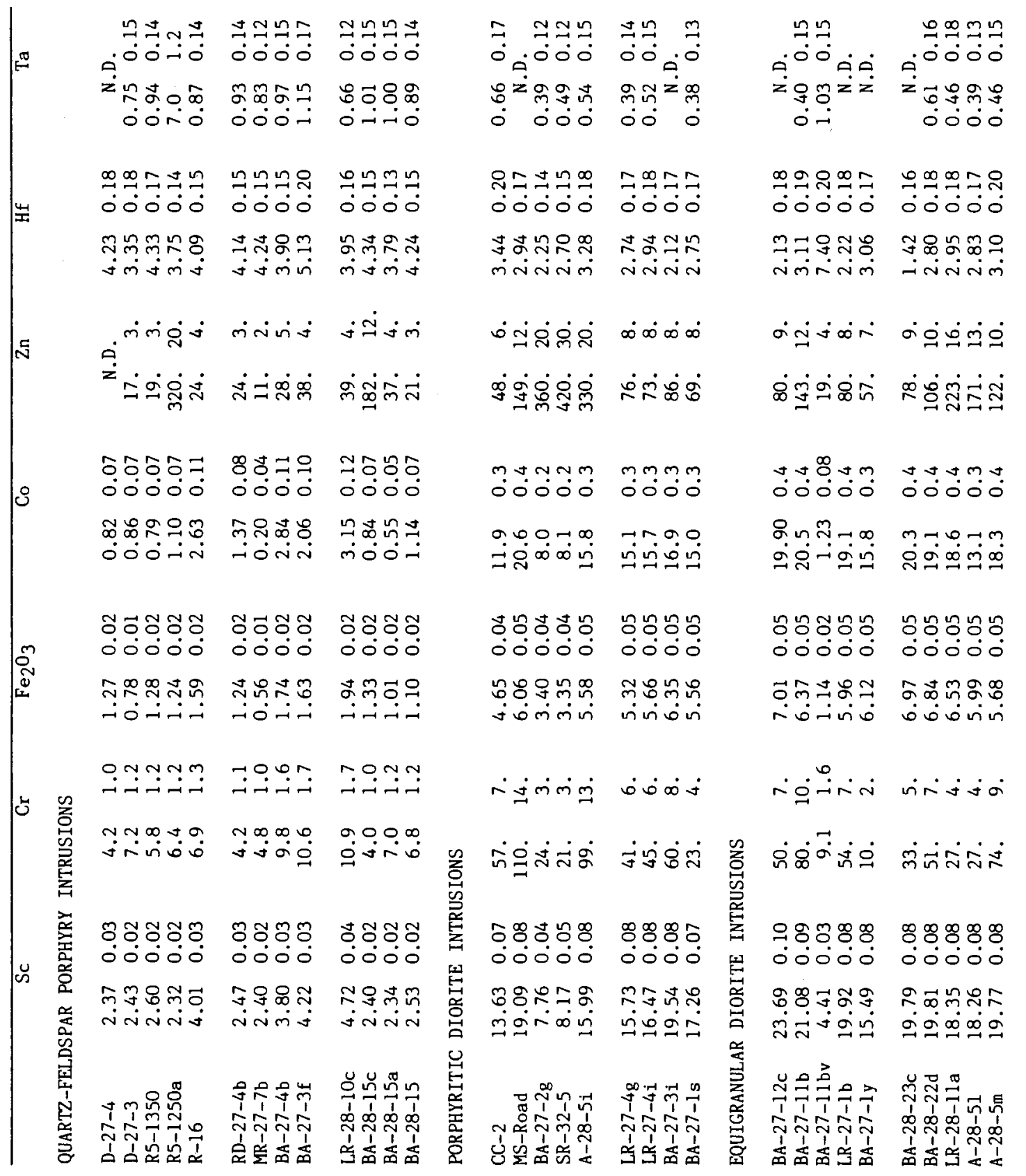




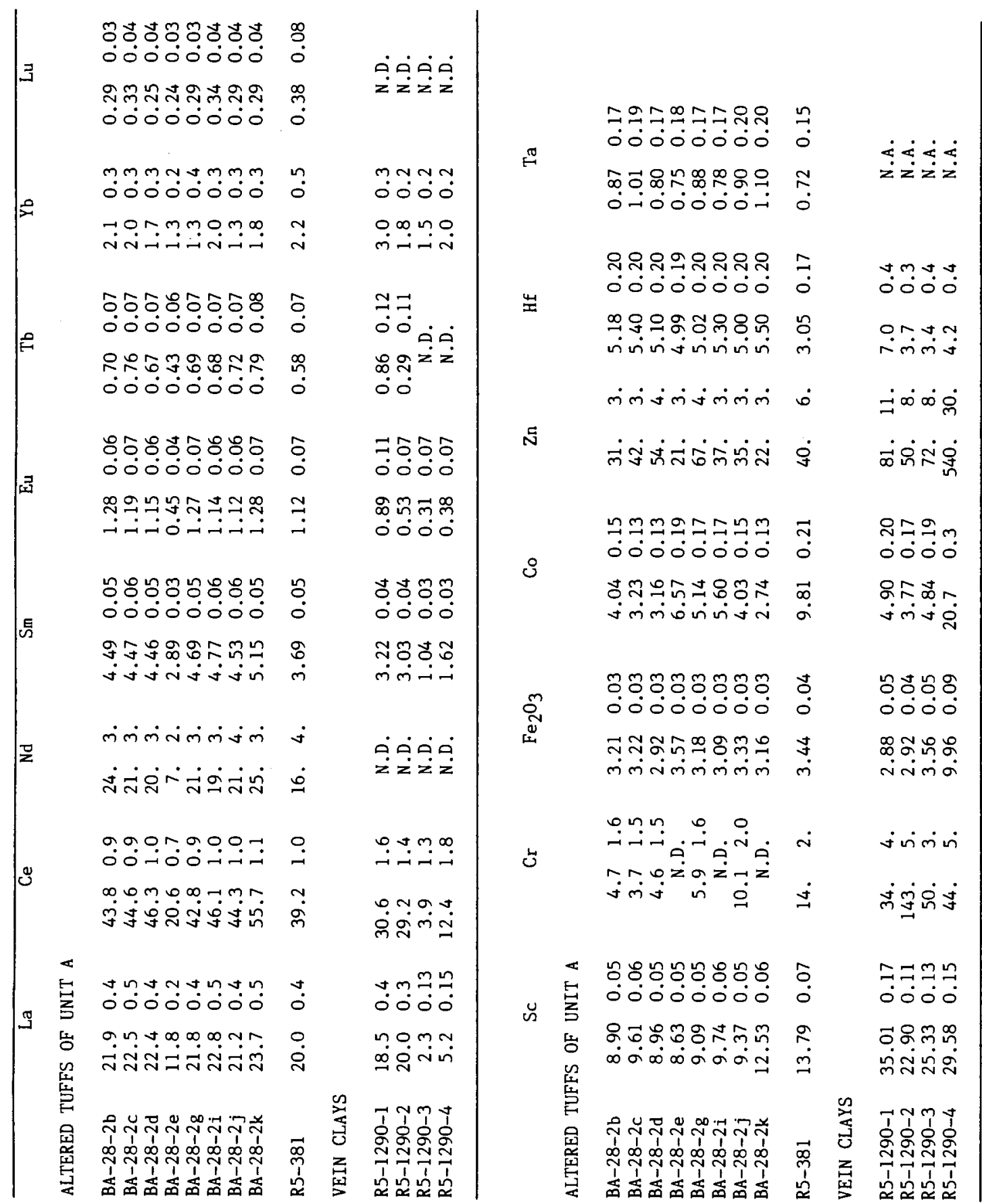




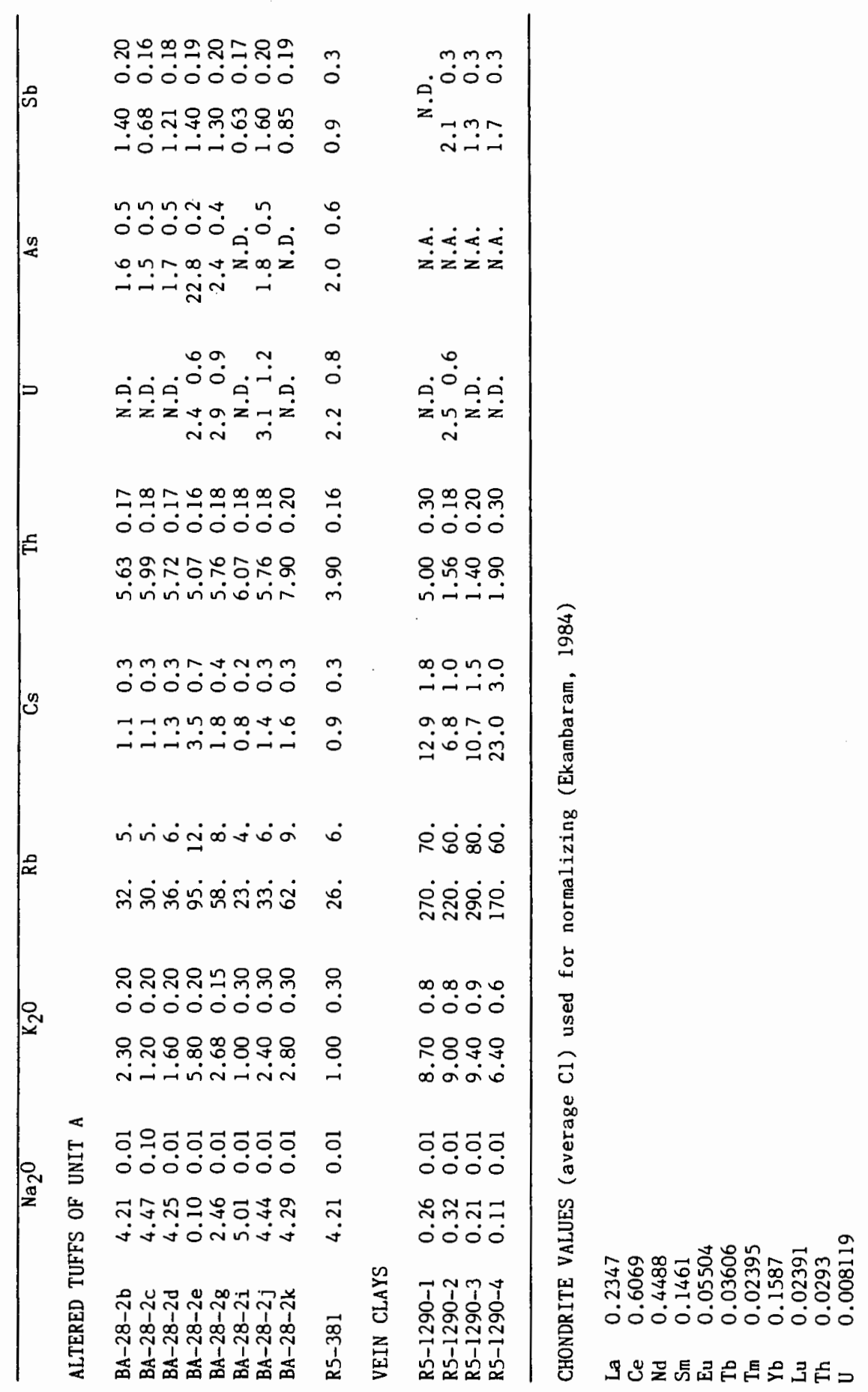

